Nevada

Environmental

Management

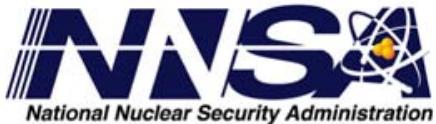

Operations Activity

Corrective Action Investigation Plan for Corrective Action Unit 571:

Area 9 Yucca Flat Plutonium

Dispersion Sites

Nevada National Security Site,

Nevada

Controlled Copy No.:

Revision No.: 0

July 2013

UNCLASSIFIED

Is/ Joseph P. Johnston, N-I CO 07/02/2013

Approved for public release; further dissemination unlimited.

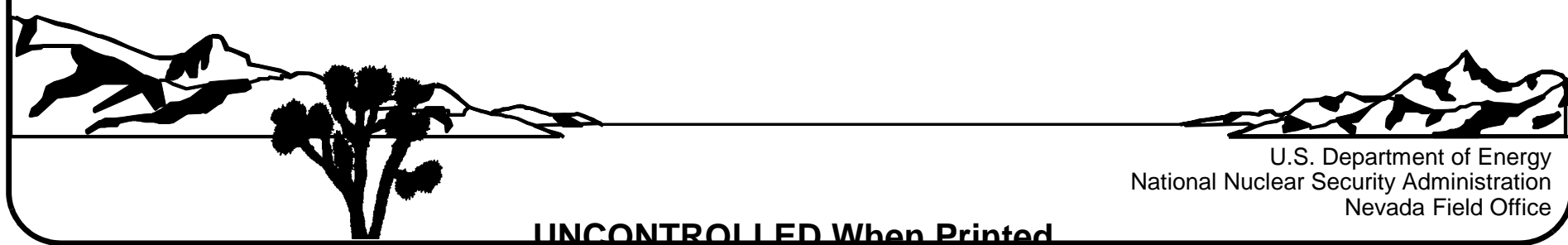


Available for sale to the public from:

U.S. Department of Commerce

National Technical Information Service

5301 Shawnee Road

Alexandria, VA 22312

Telephone: 800.553.6847

Fax: 703.605.6900

E-mail: orders@ntis.gov

Online Ordering: http://www.ntis.gov/help/ordermethods.aspx

Available electronically at http://www.osti.gov/bridge

Available for a processing fee to U.S. Department of Energy and its contractors, in paper, from:

U.S. Department of Energy

Office of Scientific and Technical Information

P.O. Box 62

Oak Ridge, TN 37831-0062

Phone: 865.576.8401

Fax: 865.576.5728

Email: reports@adonis.osti.gov

Reference herein to any specific commercial product, process, or service by trade name, trademark, manufacturer, or otherwise, does not necessarily constitute or imply its endorsement, recommendation, or favoring by the United States Government or any agency thereof or its contractors or subcontractors. 


\title{
CORRECTIVE ACTION INVESTIGATION PLAN FOR CORRECTIVE ACTION UNIT 571: AREA 9 YUCCA FLAT PLUTONIUM DISPERSION SITES NEVADA NATIONAL SECURITY SITE, NEVADA
}

\author{
U.S. Department of Energy, National Nuclear Security Administration \\ Nevada Field Office \\ Las Vegas, Nevada
}

Controlled Copy No.:

Revision No.: 0

July 2013

Approved for public release; further dissemination unlimited. 


\section{CORRECTIVE ACTION INVESTIGATION PLAN FOR CORRECTIVE ACTION UNIT 571: AREA 9 YUCCA FLAT PLUTONIUM DISPERSION SITES NEVADA NATIONAL SECURITY SITE, NEVADA}

Tiffany A. Lantow

Soils Activity Lead

Approved by: /s/ Jhon T. Carilli for

Date: 07/01/2013

Robert F. Boehlecke

Environmental Management Operations Manager 


\section{Table of Contents}

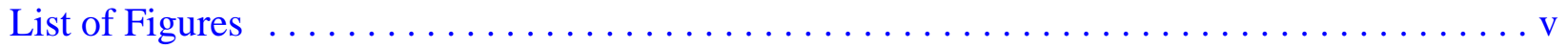

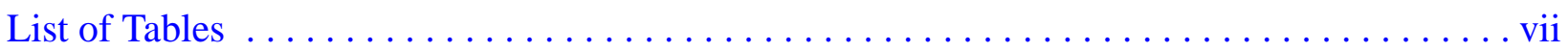

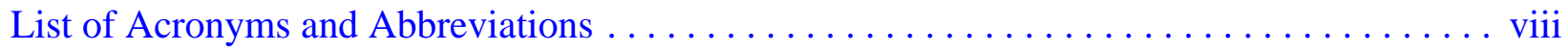

Executive Summary . . . . . . . . . . . . . . . . . . . . . . ES-1

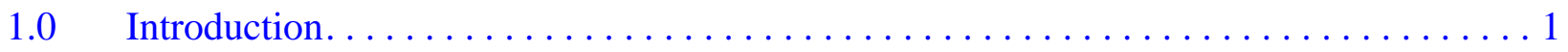

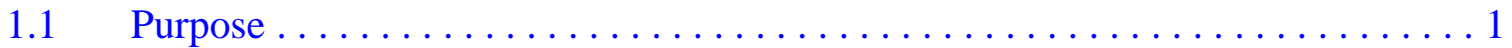

1.1.1 CAU 571 History and Description . . . . . . . . . . . . . . . 1

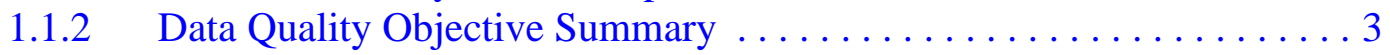

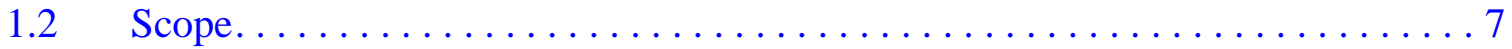

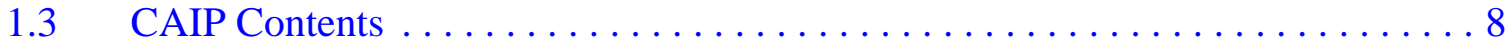

$2.0 \quad$ Facility Description. . . . . . . . . . . . . . . . . 9

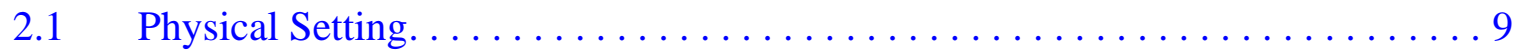

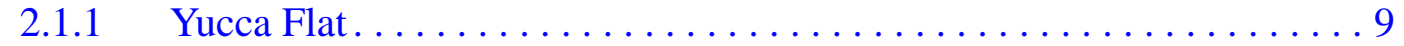

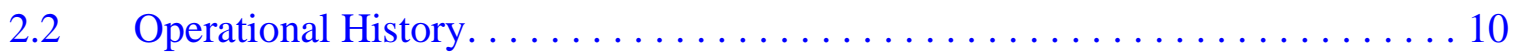

2.2.1 Post (CAS 09-23-04, Atmospheric Test Site T9-C) . . . . . . . . . . . 12

2.2.2 Juno (CAS 09-23-03, Atmospheric Test Site S-9F);

Vesta (CAS 09-23-12, Atmospheric Test Site S9-E);

Mazama (CAS 09-23-13, Atmospheric Test Site T-9D) . . . . . . . . . . 14

2.2.3 Windrows (CAS 09-45-01, Windrows Crater) . . . . . . . . . . . . . . 15

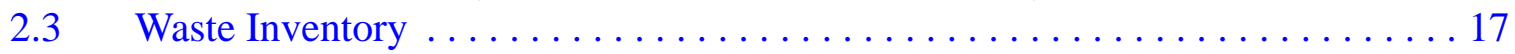

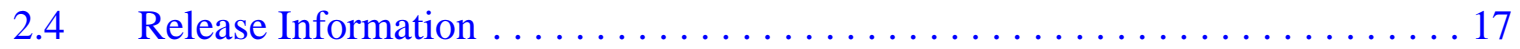

2.4.1 Study Group 1, Atmospheric Release . . . . . . . . . . . . . . . . . . 17

2.4.2 Study Group 2, Subsurface Contamination . . . . . . . . . . . . . . . 21

2.4 .3 Study Group 3, Windrows . . . . . . . . . . . . . . . 21

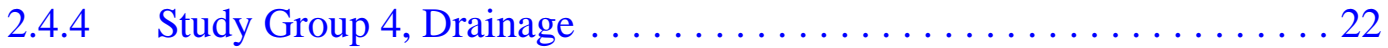

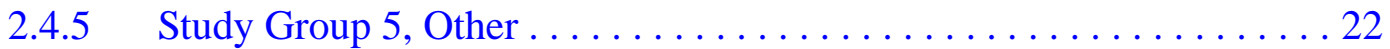

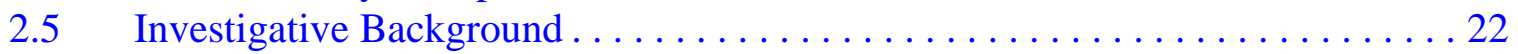

2.5.1 Area 9 Waste Consolidation . . . . . . . . . . . . . . . . 22

2.5.2 Radiological Surveys . . . . . . . . . . . . . . . . . . 23

2.5.2.1 Americium-241 and Man-made Aerial

Radiological Flyover Surveys (2012) . . . . . . . . . . . . . . . . . 23

2.5.2.2 Terrestrial Radiological Surveys . . . . . . . . . . 27

2.5.3 Radionuclide Inventory and Distribution Program . . . . . . . . . . 27

2.5.4 Preliminary Field Investigation . . . . . . . . . . . . . . . . . . 29

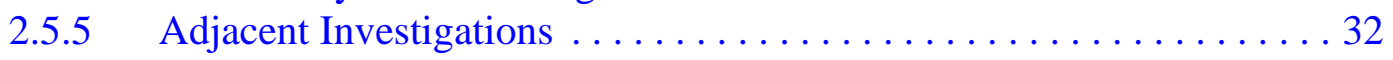

2.5.6 National Environmental Policy Act . . . . . . . . . . . . 33

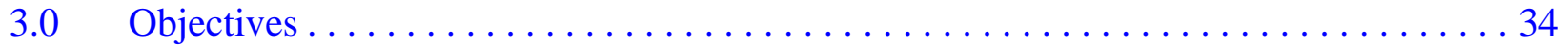

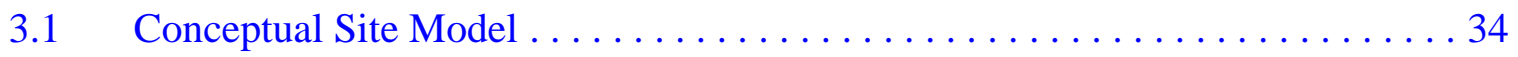




\section{Table of Contents (Continued)}

3.1.1 Land-Use and Exposure Scenarios. . . . . . . . . . . . . . 34

3.1.2 Contaminant Sources . . . . . . . . . . . . . . . . . . . 38

3.1.3 Release Mechanisms . . . . . . . . . . . . . . . . . . . . 38

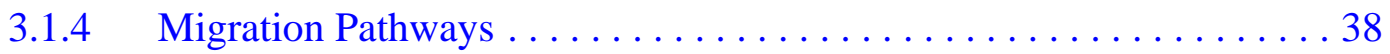

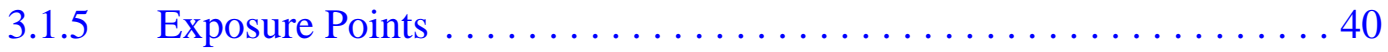

3.1.6 Exposure Routes........................ 40

$3.1 .7 \quad$ Additional Information. . . . . . . . . . . . . . . . . 40

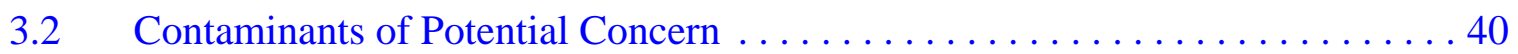

3.3 Preliminary Action Levels . . . . . . . . . . . . . . . . . . . 41

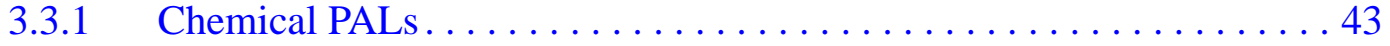

3.3.2 Radionuclide PALs........................... 44

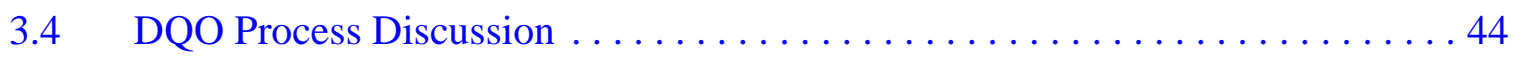

$4.0 \quad$ Field Investigation $\ldots \ldots \ldots \ldots \ldots \ldots \ldots \ldots \ldots \ldots \ldots \ldots \ldots \ldots \ldots \ldots \ldots \ldots$

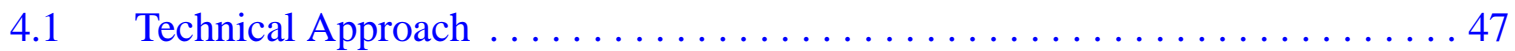

4.2 Field Activities . . . . . . . . . . . . . . . . . . . 49

4.2.1 Site Preparation Activities . . . . . . . . . . . . . . . . . . 49

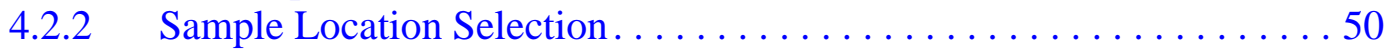

4.2.2.1 Study Group 1, Atmospheric Release . . . . . . . . . . 50

4.2.2.2 Study Group 2, Subsurface Contamination . . . . . . . 51

4.2.2.3 Study Group 3, Windrows $\ldots \ldots \ldots \ldots \ldots \ldots \ldots \ldots \ldots$

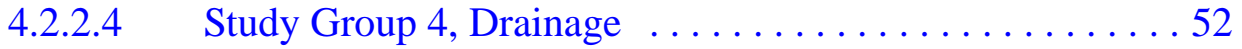

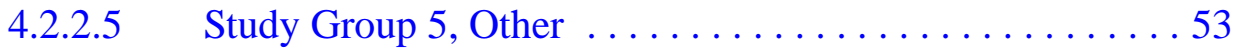

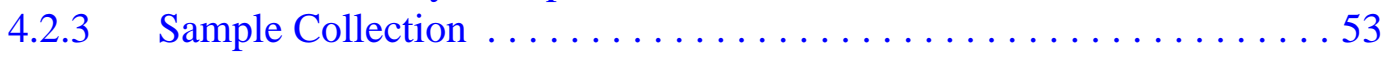

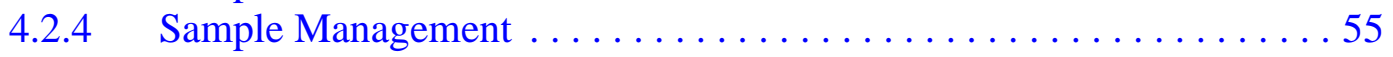

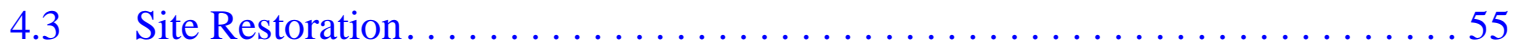

$5.0 \quad$ Waste Management . . . . . . . . . . . . . . . . . . . . 56

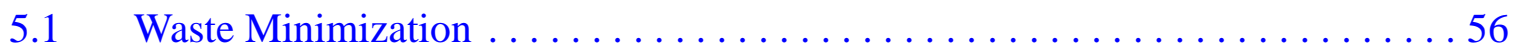

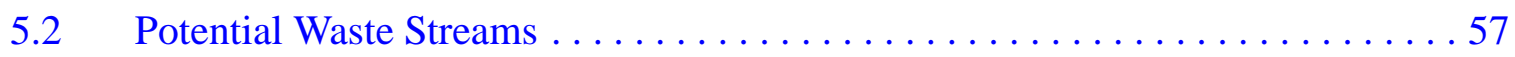

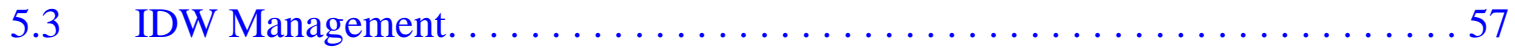

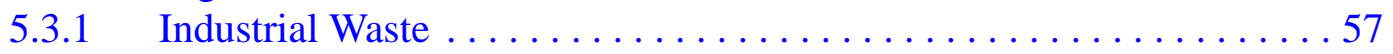

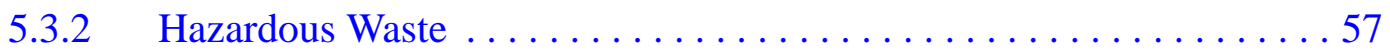

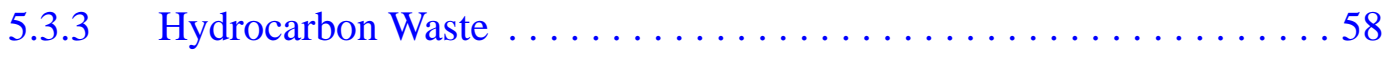

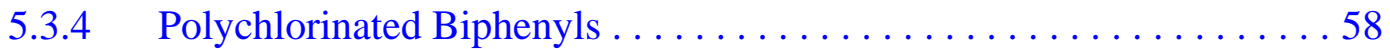

5.3 .5 Low-Level Waste . . . . . . . . . . . . . . . . . . . 58

5.3.6 Mixed Low-Level Waste . . . . . . . . . . . . . . . . . . . 58

6.0 Quality Assurance/Quality Control . . . . . . . . . . . . . . . . . . . 59

6.1 QC Sampling Activities . . . . . . . . . . . . . . . . . . 59

6.2 Laboratory/Analytical Quality Assurance $\ldots \ldots \ldots \ldots \ldots \ldots \ldots \ldots \ldots \ldots \ldots \ldots \ldots \ldots$ 


\section{Table of Contents (Continued)}

7.0 Duration and Records Availability . . . . . . . . . . . . . . . . . . . 61

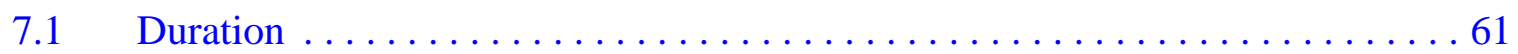

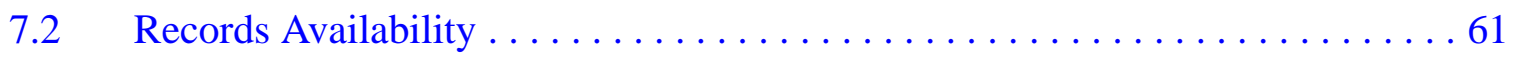

$8.0 \quad$ References........................................... 62

\section{Appendix A - Data Quality Objectives}

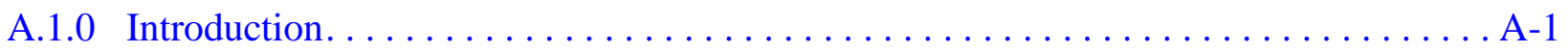

A.2.0 Step 1 - State the Problem............................... A

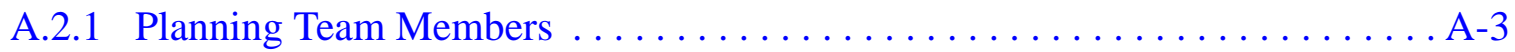

A.2.2 Conceptual Site Model $\ldots \ldots \ldots \ldots \ldots \ldots \ldots \ldots \ldots \ldots \ldots \ldots \ldots$ A-3

A.2.2.1 Release Sources .......................... A-4

A.2.2.2 Potential Contaminants......................... A-9

A.2.2.3 Contaminant Characteristics..................... A-12

A.2.2.4 Site Characteristics........................ A-13

A.2.2.5 Migration Pathways and Transport Mechanisms ............ A-14

A.2.2.6 Exposure Scenarios .......................... A-15

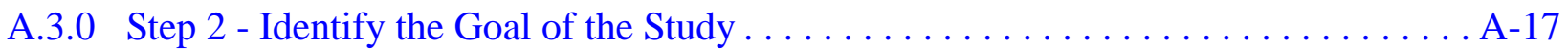

A.3.1 Decision Statements . . . . . . . . . . . . . . . . . . . . . A -17

A.3.2 Alternative Actions to the Decisions ...................... A-18

A.3.2.1 Alternative Actions to Decision I. .................. A-18

A.3.2.2 Alternative Actions to Decision II . . . . . . . . . . . . A-18

A.4.0 Step 3 - Identify Information Inputs $\ldots \ldots \ldots \ldots \ldots \ldots \ldots \ldots \ldots \ldots \ldots \ldots \ldots \ldots \ldots \ldots \ldots \ldots$

A.4.1 Information Needs . . . . . . . . . . . . . . . . . . . . . . . . A-20

A.4.2 Sources of Information . . . . . . . . . . . . . . . .

A.4.2.1 Sample Locations ........................... A-21

A.4.2.2 Analytical Methods ........................ A-21

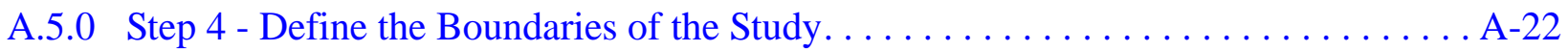

A.5.1 Target Populations of Interest . . . . . . . . . . . . . . . $\ldots \ldots \ldots \ldots$ A-22

A.5.2 Spatial Boundaries ................................ A-22

A.5.3 Practical Constraints ................................ A-23

A.5.4 Define the Sampling Units . . . . . . . . . . . . . . . . . . . . .

A.6.0 Step 5 - Develop the Analytic Approach . . . . . . . . . . . . . . . . . . . . . . A-24

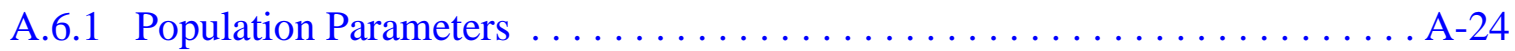

A.6.1.1 Judgmental Sampling Design..................... A-24 


\section{Table of Contents (Continued)}

A.6.1.2 Probabilistic Sampling Design . . . . . . . . . . . . . . . . A-24

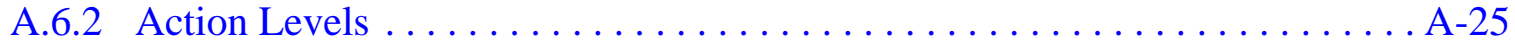

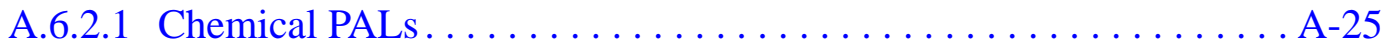

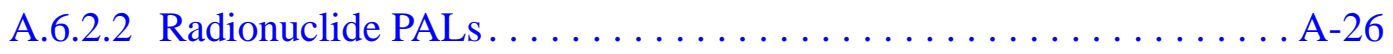

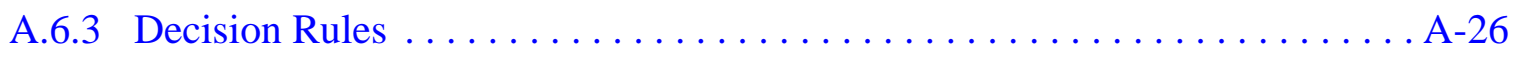

A.7.0 Step 6 - Specify Performance or Acceptance Criteria . . . . . . . . . . . . . . . . A-27

A.7.1 Decision Hypotheses. . . . . . . . . . . . . . . . . . A-27

A.7.2 False Negative Decision Error . . . . . . . . . . . . . . . . . . A A-27

A.7.2.1 False Negative Decision Error for Judgmental Sampling . . . . . . . . A-28

A.7.2.2 False Negative Decision Error for Probabilistic Sampling . . . . . . . A A-29

A.7.3 False Positive Decision Error . . . . . . . . . . . . . . . . A-30

A.8.0 Step 7 - Develop the Plan for Obtaining Data $\ldots \ldots \ldots \ldots \ldots \ldots \ldots \ldots \ldots \ldots$. . . . . . . .

A.8.1 Study Group 1, Atmospheric Release. . . . . . . . . . . . . . . . . A-31

A.8.1.1 Decision I Sample Selection. . . . . . . . . . . . . . . . A-31

A.8.1.2 Decision II Sample Selection .................. A-31

A.8.1.3 Sampling of Sample Plots . . . . . . . . . . . . . . . A-33

A.8.1.4 Calculation of Dose . . . . . . . . . . . . . . . . A-33

A.8.2 Study Group 2, Subsurface Contamination $\ldots \ldots \ldots \ldots \ldots \ldots \ldots \ldots \ldots$ A-33

A.8.2.1 Decision I Sample Selection. . . . . . . . . . . . . . . A-33

A.8.2.2 Determination of Buried Contamination . . . . . . . . . . . . A-35

A.8.3 Study Group 3, Windrows . . . . . . . . . . . . . . . . A-37

A.8.3.1 Decision I Sample Selection. . . . . . . . . . . . . . . . . A-37

A.8.3.2 Decision II Sample Selection . . . . . . . . . . . . . . . . . A-39

A.8.4 Study Group 4, Drainage . . . . . . . . . . . . . . . . . . A-39

A.8.4.1 Decision I Sample Selection. . . . . . . . . . . . . . . . . . . . . . A-39

A.8.4.2 Decision II Sample Selection . . . . . . . . . . . . . . . . . . A-40

A.8.5 Study Group 5 , Other . . . . . . . . . . . . . . . . . . . A -40

A.8.5.1 Decision I Sample Selection. . . . . . . . . . . . . . . . . . A-42

A.8.5.2 Decision II Sample Selection . . . . . . . . . . . . . . . . . A-42

A.8.6 Establishment of Final Corrective Action Boundary . . . . . . . . . . . . A-44

A.9.0 References.................................... A-45

\section{Appendix B - Activity Organization}

B.1.0 Activity Organization $\ldots \ldots \ldots \ldots \ldots \ldots \ldots \ldots \ldots \ldots \ldots \ldots \ldots \ldots \ldots \ldots \ldots \ldots \ldots$

Appendix C - Nevada Division of Environmental Protection Comments 


\section{List of Figures}

Number

Title

Page

1-1 CAU 571 CAS Location Map ................................ 2

2-1 CAU 571 CAS Locations and Radiological Demarcations.................. 11

2-2 Area 9 Decontamination Map - Post ....................... 13

2-3 Area 9 Decontamination Map - Juno, Vesta, Mazama (1959) . . . . . . . . . . . 16

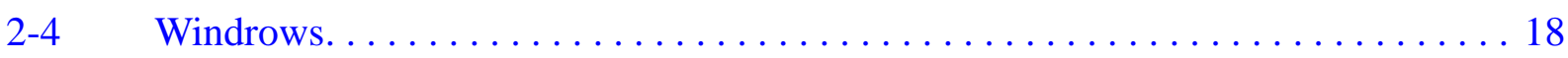

2-5 Historical Map Showing Windrow Disturbance (1963) . . . . . . . . . . . . . 19

2-6 Historical Photograph Depicting Windrow and Test Area Disturbance ......... 20

2-7 CAU 571 Am-241 Aerial Data ............................... 25

2-8 CAU 571 Man-Made Aerial Data .......................... 26

2-9 CAU 571 FIDLER Survey Results $\ldots \ldots \ldots \ldots \ldots \ldots \ldots \ldots \ldots \ldots \ldots \ldots$

2-10 CAU 571 RIDP Data.................................... 30

2-11 CAU 571 Study Group Boundaries........................... 31

3-1 CSM Diagram ..................................... 35

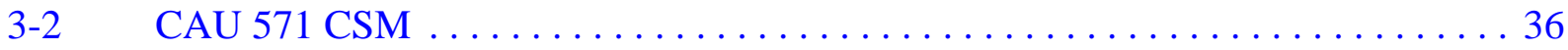

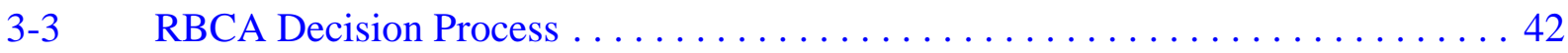

4-1 CAU 571 Default Contamination Boundaries...................... 48

A.2-1 CAU 571 CSM Pathways to Receptors......................... A-6

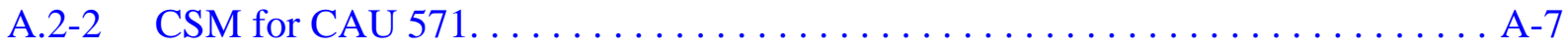

A.8-1 Decision I Sample Locations for Study Group 1, Atmospheric Release ..... . A A-32 


\section{List of Figures (Continued)}

Number

Title

Page

A.8-2 Sample Plot Sample Collection Layout. . . . . . . . . . . . . . . A-34

A.8-3 Decision I Sample Locations for Study Group 2, Subsurface Contamination . . A A-36

A.8-4 Decision I Sample Locations for Study Group 3, Windrows . . . . . . . . . . A-38

A.8-5 Decision I Sample Locations for Study Group 4, Drainage . . . . . . . . . . . A-41

A.8-6 Debris and Features for Investigation for Study Group 5, Other . . . . . . . . A-43 


\section{List of Tables}

Number

Title

Page

1-1 CAU 571 CAS Information $\ldots \ldots \ldots \ldots \ldots \ldots \ldots \ldots \ldots \ldots \ldots \ldots \ldots \ldots \ldots$

$1-2 \quad$ CAU 571 Study Groups $\ldots \ldots \ldots \ldots \ldots \ldots \ldots \ldots \ldots \ldots \ldots \ldots \ldots \ldots \ldots \ldots \ldots$

2-1 Rainfall and PET Information for Yucca Flat................... 10

2-2 Comparison of Radiation Survey Methods..................... 24

2-3 CASs Surrounding CAU $571 \ldots \ldots \ldots \ldots \ldots \ldots \ldots \ldots \ldots \ldots \ldots \ldots \ldots \ldots \ldots \ldots \ldots$

4-1 Windrow Zones................................... 52

A.2-1 CSM Description of Elements for Each Study Group in CAU $571 \ldots \ldots \ldots$ A-5

A.2-2 Contaminants of Potential Concern $\ldots \ldots \ldots \ldots \ldots \ldots \ldots \ldots \ldots \ldots$ A-9

A.2-3 Analyses Required by Study Group $\ldots \ldots \ldots \ldots \ldots \ldots \ldots \ldots \ldots \ldots \ldots \ldots \ldots$

A.2-4 Analytes Reported Per Method........................... A-11

A.2-5 Vertical Migration Potential through the Vadose Zone of the Major Radionuclide Contaminants................... A-13

A.2-6 Land-Use and Exposure Scenarios $\ldots \ldots \ldots \ldots \ldots \ldots \ldots \ldots \ldots \ldots \ldots$ A-16 


\section{List of Acronyms and Abbreviations}

Ac

Ag

$\mathrm{Al}$

Am

ASTM

bgs

BJY

CA

CAA

CAI

CAIP

CAS

CAU

CERCLA

CFR

$\mathrm{cm}$

$\mathrm{Cm}$

Co

COC

COPC

cps

Cs

CSM

CWD

DOE

DQI
Actinium

Silver

Aluminum

Americium

ASTM International

Below ground surface

Buster Jangle Y

Contamination area

Corrective action alternative

Corrective action investigation

Corrective action investigation plan

Corrective action site

Corrective action unit

Comprehensive Environmental Response, Compensation, and Liability Act

Code of Federal Regulations

Centimeter

Curium

Cobalt

Contaminant of concern

Contaminant of potential concern

Counts per second

Cesium

Conceptual site model

Contaminated waste dump

U.S. Department of Energy

Data quality indicator 


\section{List of Acronyms and Abbreviations (Continued)}

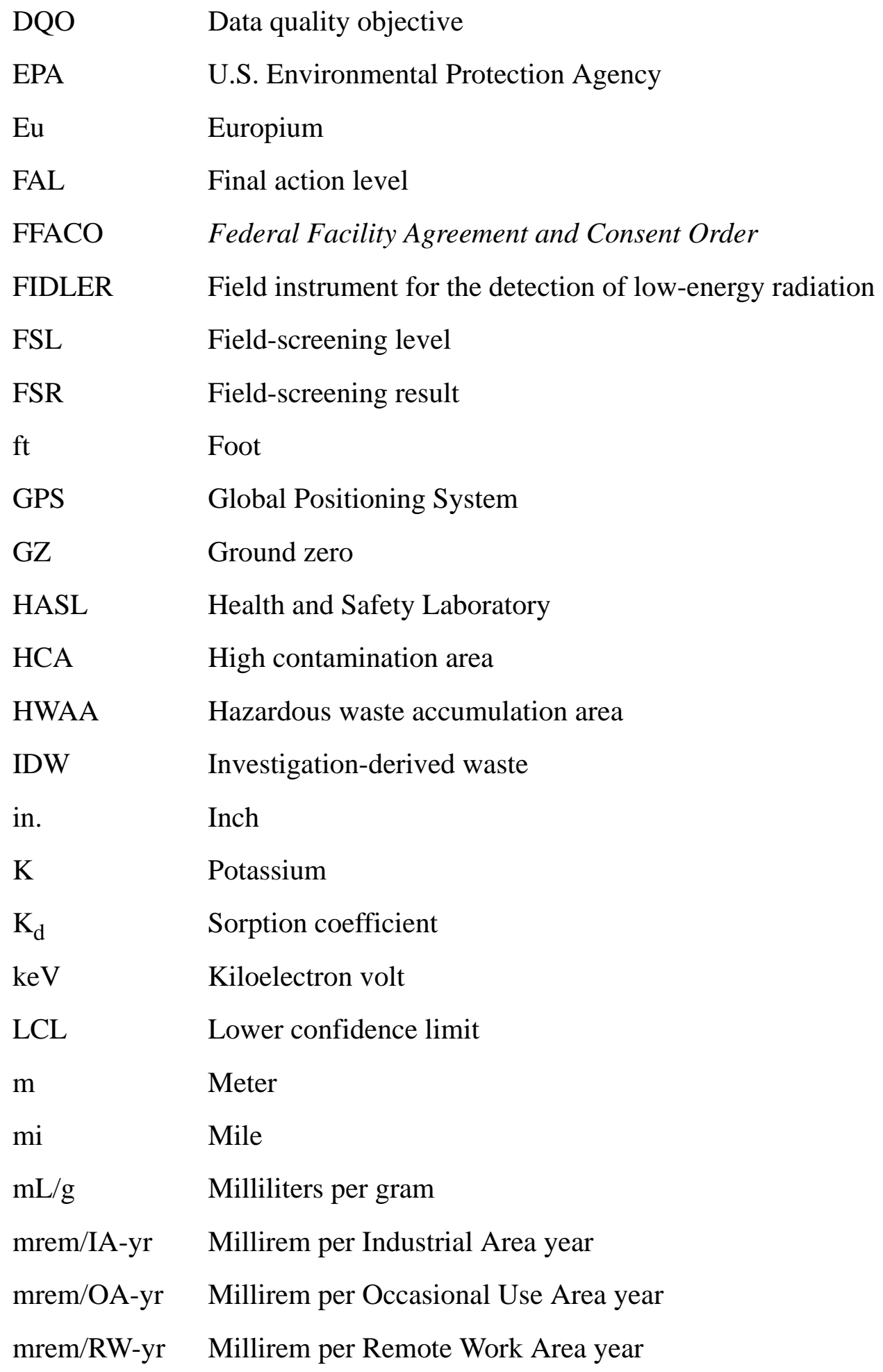




\section{List of Acronyms and Abbreviations (Continued)}

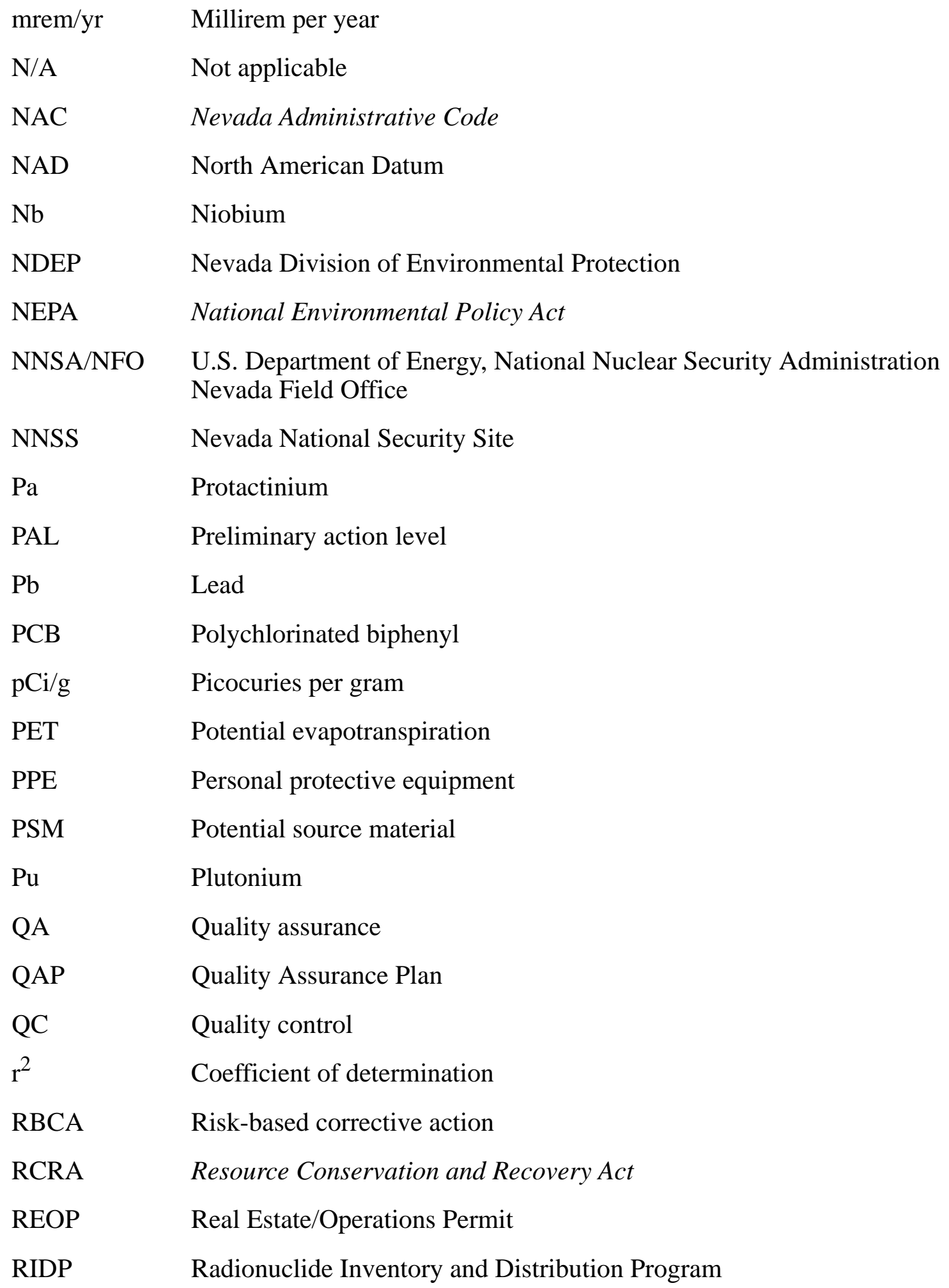




\section{List of Acronyms and Abbreviations (Continued)}

\begin{tabular}{ll} 
RMA & Radioactive material area \\
RRMG & Residual radioactive material guideline \\
RWMS & Radioactive waste management site \\
SOW & Statement of Work \\
SVOC & Semivolatile organic compound \\
TED & Total effective dose \\
Th & Thorium \\
Tl & Thallium \\
TLD & Thermoluminescent dosimeter \\
TPH & Total petroleum hydrocarbons \\
TSCA & Toxic Substances Control Act \\
U & Uranium \\
UCC & Yucca Dry Lake \\
UCL & Upper confidence limit \\
URMA & Underground radioactive material area \\
USGS & U.S. Geological Survey \\
UST & Underground storage tank \\
UTM & Universal Transverse Mercator \\
VOC & Volatile organic compound \\
yd & Cubic yard \\
\hline &
\end{tabular}




\section{Executive Summary}

Corrective Action Unit (CAU) 571 is located in Area 9 of the Nevada National Security Site, which is approximately 65 miles northwest of Las Vegas, Nevada. CAU 571 is a grouping of sites where there has been a suspected release of contamination associated with nuclear testing. This document describes the planned investigation of CAU 571, which comprises the following corrective action sites (CASs):

- 09-23-03, Atmospheric Test Site S-9F

- 09-23-04, Atmospheric Test Site T9-C

- 09-23-12, Atmospheric Test Site S-9E

- 09-23-13, Atmospheric Test Site T-9D

- 09-45-01, Windrows Crater

These sites are being investigated because existing information on the nature and extent of potential contamination is insufficient to evaluate and recommend corrective action alternatives (CAAs). Additional information will be obtained by conducting a corrective action investigation before evaluating CAAs and selecting the appropriate corrective action for each CAS. The results of the field investigation will support a defensible evaluation of viable CAAs that will be presented in the investigation report.

The sites will be investigated based on the data quality objectives (DQOs) developed on March 6, 2013, by representatives of the Nevada Division of Environmental Protection and the U.S. Department of Energy (DOE), National Nuclear Security Administration Nevada Site Office (now the Nevada Field Office). The DQO process was used to identify and define the type, amount, and quality of data needed to develop and evaluate appropriate corrective actions for CAU 571. The site investigation process will also be conducted in accordance with the Soils Activity Quality Assurance Plan, which establishes requirements, technical planning, and general quality practices to be applied to this activity.

The potential contamination sources associated with CAU 571 CASs are from nuclear testing activities. The DQO process resulted in an assumption that total effective dose (TED) within a default contamination boundary exceeds the final action level (FAL) and requires corrective action. The presence and nature of contamination outside the default contamination boundaries at CAU 571 will 
be evaluated based on information collected from a field investigation. Radiological contamination will be evaluated based on a comparison of the TED at sample locations to the dose-based FAL. The TED will be calculated as the total of separate estimates of internal and external dose. Results from the analysis of soil samples will be used to calculate internal radiological dose. Thermoluminescent dosimeters placed at the center of each sample location will be used to measure external radiological dose. Chemical contamination will be evaluated by comparing soil sample results to the FAL.

Appendix A provides a detailed discussion of the DQO methodology and the DQOs specific to each CAS.

This Corrective Action Investigation Plan has been developed in accordance with the Federal Facility Agreement and Consent Order that was agreed to by the State of Nevada; DOE, Environmental Management; U.S. Department of Defense; and DOE, Legacy Management. Under the Federal Facility Agreement and Consent Order, this Corrective Action Investigation Plan will be submitted to the Nevada Division of Environmental Protection for approval. Fieldwork will be conducted after the plan is approved. 
This Corrective Action Investigation Plan (CAIP) contains activity-specific information, including facility descriptions, environmental sample collection objectives, and criteria for conducting site investigation activities at Corrective Action Unit (CAU) 571: Area 9 Yucca Flat Plutonium Dispersion Sites, Nevada National Security Site (NNSS), Nevada.

This CAIP has been developed in accordance with the Federal Facility Agreement and Consent Order (FFACO) (1996, as amended) that was agreed to by the State of Nevada; U.S. Department of Energy (DOE), Environmental Management; U.S. Department of Defense; and DOE, Legacy Management.

CAU 571 is located in Area 9 of the NNSS, which is approximately 65 miles (mi) northwest of Las Vegas, Nevada. CAU 571 comprises the five corrective action sites (CASs) shown on Figure 1-1 and listed in Table 1-1.

The corrective action investigation (CAI) will include field inspections, radiological surveys, sampling of environmental media, analysis of samples, and assessment of investigation results. Data will be obtained to support evaluations of corrective action alternatives (CAAs) and waste management decisions.

\subsection{Purpose}

The CASs in CAU 571 are being investigated because hazardous and/or radioactive contaminants may be present in concentrations that exceed risk-based corrective action (RBCA) levels. Existing information on the nature and extent of potential contamination is insufficient to evaluate and recommend CAAs for the CASs. Additional information will be generated by conducting a CAI before evaluating and selecting CAAs.

\subsubsection{CAU 571 History and Description}

CAU 571, Area 9 Yucca Flat Plutonium Dispersion Sites, consists of five inactive sites located in the western portion of Area 9. The CAU 571 sites consist of releases of radionuclides to surface and 


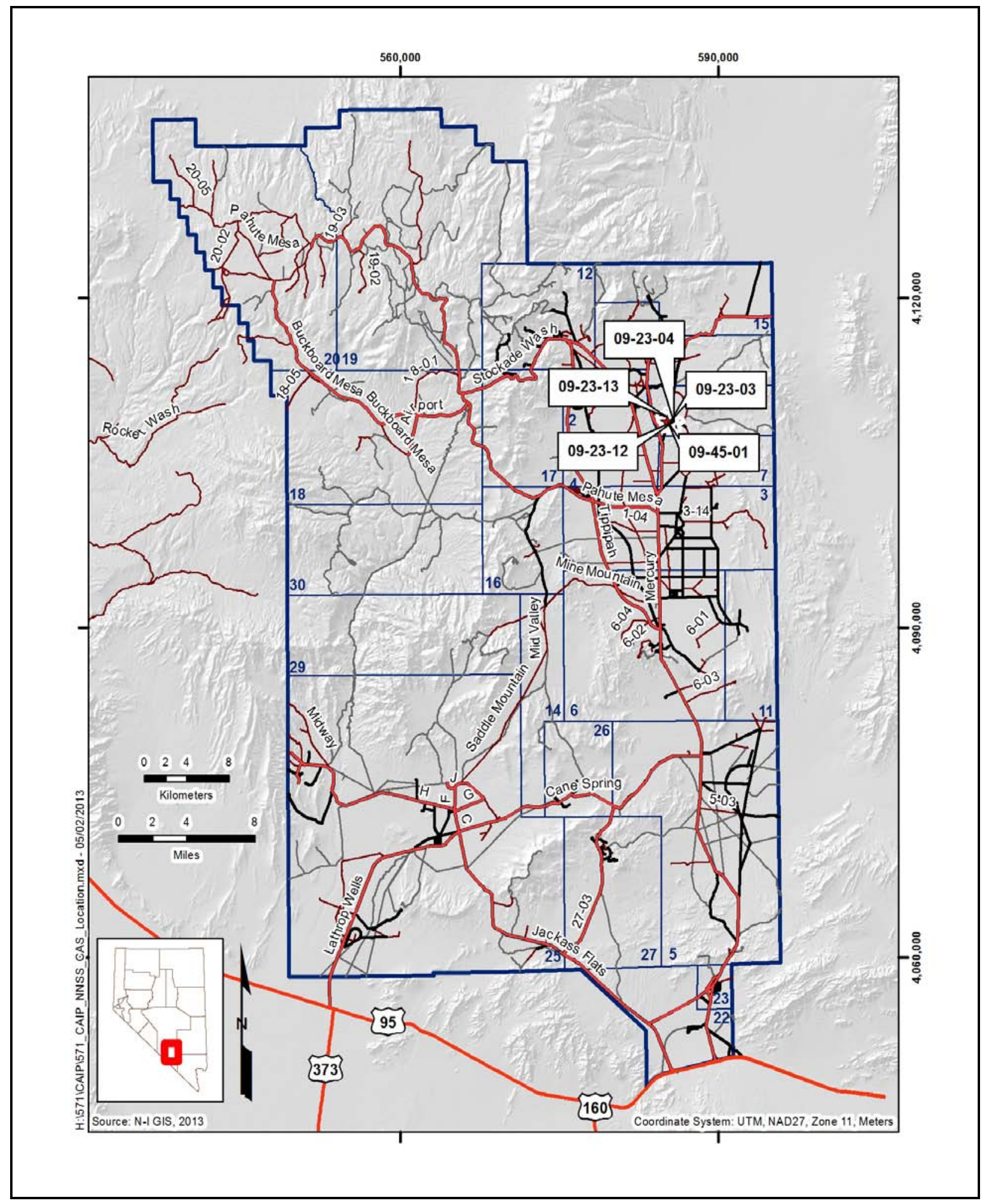

Figure 1-1

CAU 571 CAS Location Map 
Table 1-1

\section{CAU 571 CAS Information}

\begin{tabular}{|c|c|c|c|c||}
\hline CAS Number & CAS Name & Associated Tests & Site & Site Name \\
\hline \hline $09-23-03$ & Atmospheric Test Site S-9F & Juno & $9 \mathrm{~F}$ & Juno \\
\hline $09-23-04$ & Atmospheric Test Site T9-C & Post & $9 \mathrm{C}$ & Post \\
\hline $09-23-12$ & Atmospheric Test Site S-9E & Vesta & $9 \mathrm{E}$ & Vesta \\
\hline $09-23-13$ & Atmospheric Test Site T-9D & Mazama & $9 \mathrm{D}$ & Mazama \\
\hline $09-45-01$ & Windrows Crater & Juno, Vesta, Mazama & N/A & Windrows \\
\hline
\end{tabular}

N/A = Not applicable

subsurface soil from the conduct of nuclear testing in the mid- to late 1950s and the subsequent activities in the area. Operational histories for each CAU 571 site are detailed in Section 2.2.

\subsubsection{Data Quality Objective Summary}

The sites will be investigated based on data quality objectives (DQOs) developed by representatives of the Nevada Division of Environmental Protection (NDEP) and the DOE, National Nuclear Security Administration Nevada Field Office (NNSA/NFO). DQOs are used to identify and define the type, amount, and quality of data needed to develop and evaluate appropriate corrective actions for CAU 571. This CAIP describes the investigative approach developed to collect the necessary data identified in the DQO process. Discussions of the DQO methodology and the DQOs specific to CAU 571 are presented in Appendix A. A summary of the DQO process is provided below.

The DQO problem statement for CAU 571 is as follows: "Existing information on the nature and extent of potential contamination is insufficient to evaluate and recommend CAAs for the CASs in CAU 571.” To address this problem, resolution of the following decision statements is required:

- Decision I. "Is any contaminant of concern (COC) associated with the CAU 571 release present in environmental media?” Any contaminant that is present (or assumed to be present) at concentrations exceeding its corresponding final action level (FAL) will be defined as a COC. A COC may also be defined as a contaminant that, in combination with other like contaminants, is determined to jointly pose an unacceptable risk based on a multiple constituent analysis (NNSA/NSO, 2012c). 
- Decision II. “Is sufficient information available to evaluate potential CAAs?” Sufficient information is defined to include the following:

- The lateral and vertical extent of COC contamination

- The information needed to predict potential remediation waste types and volumes

- Any other information needed to evaluate the feasibility of remediation alternatives

A corrective action will be determined for any site containing a COC. The evaluation of the need for corrective action will include the potential for wastes that are present at the site to contain contaminants that, if released, could cause the surrounding environmental media to contain COCs. Such a waste will be evaluated using the potential source material (PSM) criteria listed in the Soils RBCA document (NNSA/NSO, 2012c) to determine the need for corrective action.

The informational inputs and data needs to resolve the problem statement and the decision statements were generated as part of the DQO process for this CAU and are documented in Appendix A. The information necessary to resolve the DQO decisions will be generated for each CAU 571 CAS by collecting and analyzing samples generated during a field investigation. The presence of a COC will be determined by collecting and analyzing samples from locations determined most likely to contain a COC (based on the presence of a biasing factor).

The judgmental sampling design will be used to collect samples from biased locations. Results from these locations can only be used to infer a characteristic (e.g., average concentration) of the sampled location (i.e., not an area). The characteristic normally used to define contamination at a location is the contaminant concentration or dose from a single sample or the average if more than one sample is collected from the location. When the sample is collected from the location of the greatest degree of the selected biasing factor, this represents the maximum dose or contaminant concentration at the release site.

A probabilistic sampling design will be used to collect samples from unbiased locations within an area that can be readily defined by distinct characteristics where the assumed distribution of contamination is relatively uniform. Results from these locations will be used to infer a characteristic representative of the sampled area as a whole (i.e., representing the average of the entire area, not the maximum at any one location). The characteristic normally used to define contamination within an area is the 95 percent upper confidence limit (UCL) of the mean concentration or dose. 
Protection against false negative decision errors are provided by the following:

- Judgmental sampling when contamination concentrations or dose levels from locations of the greatest degree of the selected biasing factor are used to make decisions for a larger area (e.g., a release site).

- Probabilistic sampling when the 95 percent UCL of the mean concentration or dose is used to make decisions for the defined sampling area.

Decisions are even more conservative when probabilistic results (i.e., 95 percent UCL) from biased locations are used to make a decision on the presence of COCs for the entire release site. This is typically the case when the 95 percent UCL of contamination at a sample plot located in the area of the highest radiation survey values are used to resolve the decision on the presence of COCs (i.e., Decision I).

DQOs for CAU 571 defined similarities in conceptual site model (CSM) properties of several releases that would allow a common investigative approach (e.g., surface deposition of relatively immobile contaminants, migration and mixing of contaminants in drainage channels, or similarities in release sources such as weapons tests or safety experiments). Based on these similarities, the following study groups were established to simplify the planning and investigation of various releases:

- Study Group 1, Atmospheric Release: This release category is specific to the atmospheric deposition of radionuclide contamination from weapons-related tests and safety experiments. The release is composed mainly of fission and activated products from the weapons tests and unfissioned nuclear material (from the scattering of nuclear material due to the detonation of chemical explosives) from safety tests onto the soil surface that has not been displaced through excavation or migration. The contamination associated with this type of release will be limited to the top 5 centimeters $(\mathrm{cm})$ of soil. Atmospheric releases of radionuclides that have been distributed at the NNSS from nuclear testing have been found to be concentrated in the upper $5 \mathrm{~cm}$ of undisturbed soil (McArthur and Kordas, 1983 and 1985; Gilbert et al., 1977; Tamura, 1977).

- Study Group 2, Subsurface Contamination: This group investigates radionuclide contamination that was initially deposited on the soil surface but has subsequently been displaced or covered through mechanical means (e.g., scraping, reworking of soil for subsequent activities in the area). 
- Study Group 3, Windrows: This group investigates radionuclide contamination that was initially deposited on the soil surface but was subsequently scraped into rows. A portion of the original windrows exists, while some of the windrows have been disturbed.

- Study Group 4, Drainage: This group investigates radionuclide contamination that was initially deposited onto the soil surface but has subsequently been displaced through erosion.

- Study Group 5, Other: This group investigates any chemical or radiological contamination associated with features or items that do no fall within any of the previous study groups. This may include items such as debris, spills, contaminated areas, and piles/mounds. The debris will be evaluated for PSM, and spills will be evaluated based on the presence of biasing factors such as discoloration or elevated instrument readings. Other features such as an asphalt pile and an area of radiologically contaminated soil have been identified and will be included in this study group.

The study groups and the CASs associated with each study group are described in Table 1-2. Although the need for corrective action is evaluated separately for each study group, CAAs are evaluated for each FFACO CAS.

Table 1-2

CAU 571 Study Groups

\begin{tabular}{||c|c|c||}
\hline Number & Description & FFACO CASs and Associated Site Names \\
\hline \hline Study Group 1 & Atmospheric Release & $\begin{array}{c}\text { 09-23-03 (Juno), 09-23-04 (Post), 09-23-12 (Vesta), } \\
\text { and 09-23-13 (Mazama) }\end{array}$ \\
\hline Study Group 2 & $\begin{array}{c}\text { Subsurface } \\
\text { Contamination }\end{array}$ & $\begin{array}{c}\text { 09-23-03 (Juno), 09-23-04 (Post), 09-23-12 (Vesta), } \\
\text { and 09-23-13 (Mazama) }\end{array}$ \\
\hline Study Group 3 & Windrows & 09-45-01 (Windrows) \\
\hline Study Group 4 & Drainage & 09-23-03 (Juno), 09-23-04 (Post), and 09-23-12 (Vesta) \\
\hline Study Group 5 & Other & 09-23-03 (Juno) and 09-23-12 (Vesta) \\
\hline
\end{tabular}

The RBCA dose evaluation does not address the potential for removable contamination under different exposure scenarios if it were to be transported to other areas. A discussion on the risks associated with removable radioactive contamination is presented in the Soils Risk-Based Corrective Action Evaluation Process (NNSA/NSO, 2012c). This discussion proposes a requirement for corrective action at areas that exceed high contamination area (HCA) criteria even though the area may not present a potential radiation dose to a receptor that exceeds the FAL. Therefore, it is assumed that removable contamination that exceeds HCA criteria requires corrective action. Therefore, the 
HCAs at CAU 571 will require corrective action, and the CAI will address releases outside the default contamination boundaries. See Section 4.1 for details regarding the default contamination boundaries.

Subsidence craters affect the closure of Soils Activity sites when there has been a release of radioactivity to the surface from the associated underground test or when other atmospheric releases of contamination overlap the area of the subsidence crater. Subsidence craters are considered to be the area above underground nuclear tests that have formed a surface crater or have the potential to form a surface crater. These areas have been determined to pose a significant physical safety hazard, and most are fenced and/or posted to keep workers from inadvertently being exposed to this hazard. The following subsidence craters in the vicinity of CAU 571 have a documented release of radioactivity to the atmosphere and will be included in the CAI: U9g (Codsaw), U9ay (Oconto), U9ar (Driver), and U9w (Kootanai).

These subsidence craters will be evaluated using the subsidence crater strategy as presented in the Soils Risk-Based Corrective Action Evaluation Process (NNSA/NSO, 2012c). Subsidence craters that have been determined to have a sufficiently low potential for additional subsidence will be investigated without regard to the crater or potential crater area.

\subsection{Scope}

To generate information needed to resolve the decision statements identified in the DQO process, the scope of the CAI for CAU 571 includes the following activities:

- $\quad$ Move surface debris and/or materials, as needed, to facilitate sampling.

- Conduct radiological surveys.

- $\quad$ Perform field screening.

- Measure in situ external dose rates using thermoluminescent dosimeters (TLDs) or other dose-measurement devices.

- Collect and submit environmental samples for laboratory analysis to determine whether any COC is present.

- Collect and submit environmental samples for laboratory analysis to determine the nature and extent of any COCs that are present. 
- Collect samples of waste material, if present, to determine the potential for a release to result in contamination exceeding FALs.

- Collect samples of potential remediation wastes, if present.

- Collect quality control (QC) samples.

Contamination of environmental media originating from activities not identified in the CSM of any CAS will not be considered as part of this CAU unless the CSM and the DQOs are modified to include the release. If not included in the CSM, contamination originating from these sources will not be considered for sample location selection and/or will not be considered COCs. If such contamination is present, the contamination will be identified as part of another CAS (either new or existing).

\subsection{CAIP Contents}

Section 1.0 presents the purpose and scope of this CAIP, while Section 2.0 provides background information about CAU 571. Objectives of the investigation, including the CSM, are presented in Section 3.0. Field investigation and sampling activities are discussed in Section 4.0, and waste management issues are discussed in Section 5.0. General field and laboratory quality assurance (QA) (including collection of QA samples) is presented in Section 6.0 and in the Soils Activity Quality Assurance Plan (QAP) (NNSA/NSO, 2012b). The activity schedule and records availability are discussed in Section 7.0. Section 8.0 provides a list of references.

Appendix A provides a detailed discussion of the DQO methodology and the DQOs specific to each CAS, while Appendix B contains information on the activity organization. Appendix C contains NDEP comments on the draft version of the document. 


\subsection{Facility Description}

CAU 571 comprises five CASs at the NNSS. All of the CASs are located in Area 9 and consist of radiological and chemical releases associated with four atmospheric tests as well as the subsequent decontamination of these four test areas.

\subsection{Physical Setting}

The following sections describe the general physical settings of Area 9 of the NNSS. General background information pertaining to topography, geology, hydrogeology, and climatology is provided for these specific areas of the NNSS region in the Geologic Map of the Nevada Test Site, Southern Nevada (Frizzell and Shulters, 1990); CERCLA Preliminary Assessment of DOE's Nevada Operations Office Nuclear Weapons Testing Areas (DRI, 1988); Final Environmental Impact Statement, Nevada Test Site, Nye County, Nevada (ERDA, 1977); and the Final Environmental Impact Statement for the Nevada Test Site and Off-Site Locations in the State of Nevada (DOE/NV, 1996).

Geological and hydrological setting descriptions for each of the sites are detailed in the following subsections based on the hydrogeographic area in which they are located.

\subsubsection{Yucca Flat}

All of the CAU 571 CASs are located within the Yucca Flat Hydrographic Area of the NNSS. Yucca Flat is a closed basin, which is slowly being filled with alluvial deposits eroding from the surrounding mountains (Laczniak et al., 1996).

Local topography around the CASs is relatively flat, with low-lying mountains east of the site. Precipitation runoff flow is generally to the south and east. A small wash travels along the southern side of the 9-01 Road; however, the most notable wash in the area is located west of CAS 09-23-13 and is being investigated in CAU 570, Area 9 Yucca Flat Atmospheric Test Sites. These washes and other ephemeral channels that flow through the area generally flow south toward the Yucca Flat dry lake. Several craters are present in and around the CAU, and evidence suggests that runoff throughout the area drains into these craters. 
CAU 571 is located within the Yucca Flat Tributary Flow System, a part of regional carbonate aquifer flow system, and flow moves generally from northeast to southwest (Fenelon et al., 2010). Within the overlying alluvial and volcanic aquifers, lateral groundwater flow occurs from the margins to the center of the basin and downward into the carbonate aquifer (Laczniak et al., 1996). The average annual precipitation is 6.35 inches (in.) at the Buster Jangle Y (BJY) rain gauge and 6.70 in. at the Yucca Dry Lake (UCC) rain gauge. Average annual potential evapotranspiration (PET) has been estimated for the Area 3 Radioactive Waste Management Site (RWMS) as 61.81 in. (Soule', 2006; Yucel, 2009). Rainfall and PET data are presented in Table 2-1.

Table 2-1

Rainfall and PET Information for Yucca Flat

\begin{tabular}{|c|c|c|c|}
\hline & $\begin{array}{c}\text { BJY Precipitation } \\
\text { (in.) }\end{array}$ & $\begin{array}{c}\text { UCC Precipitation } \\
\text { (in.) }\end{array}$ & $\begin{array}{c}\text { Area 3 PET } \\
\text { (in.) }\end{array}$ \\
\hline \hline Minimum & 1.50 & 1.14 & 59.13 \\
\hline Maximum & 14.71 & 16.21 & 63.31 \\
\hline Mean & 6.35 & 6.70 & 61.81 \\
\hline $95 \% \mathrm{UCL}$ & 7.17 & 7.56 & 62.83 \\
\hline
\end{tabular}

Source: Soule', 2006; Yucel, 2009

The nearest groundwater well to CAU 571 is U.S. Geological Survey (USGS) ER-2-1, an active well located approximately $1.3 \mathrm{mi}$ west of the site. The most recent recorded depth to the water table is approximately 1,725 feet (ft) below ground surface (bgs) (USGS, 2013).

\subsection{Operational History}

The following subsections provide a description of the use and history of each site in CAU 571 that may have resulted in releases of contaminants to the environment. The site-specific summaries are designed to describe the current definition of each site and document all significant, known activities. Figure 2-1 shows the ground zero (GZ) of each test-related CAS as well as the general location of the windrows CAS. Also included are the current radiological demarcation fence lines for the features of interest in CAU 571. 


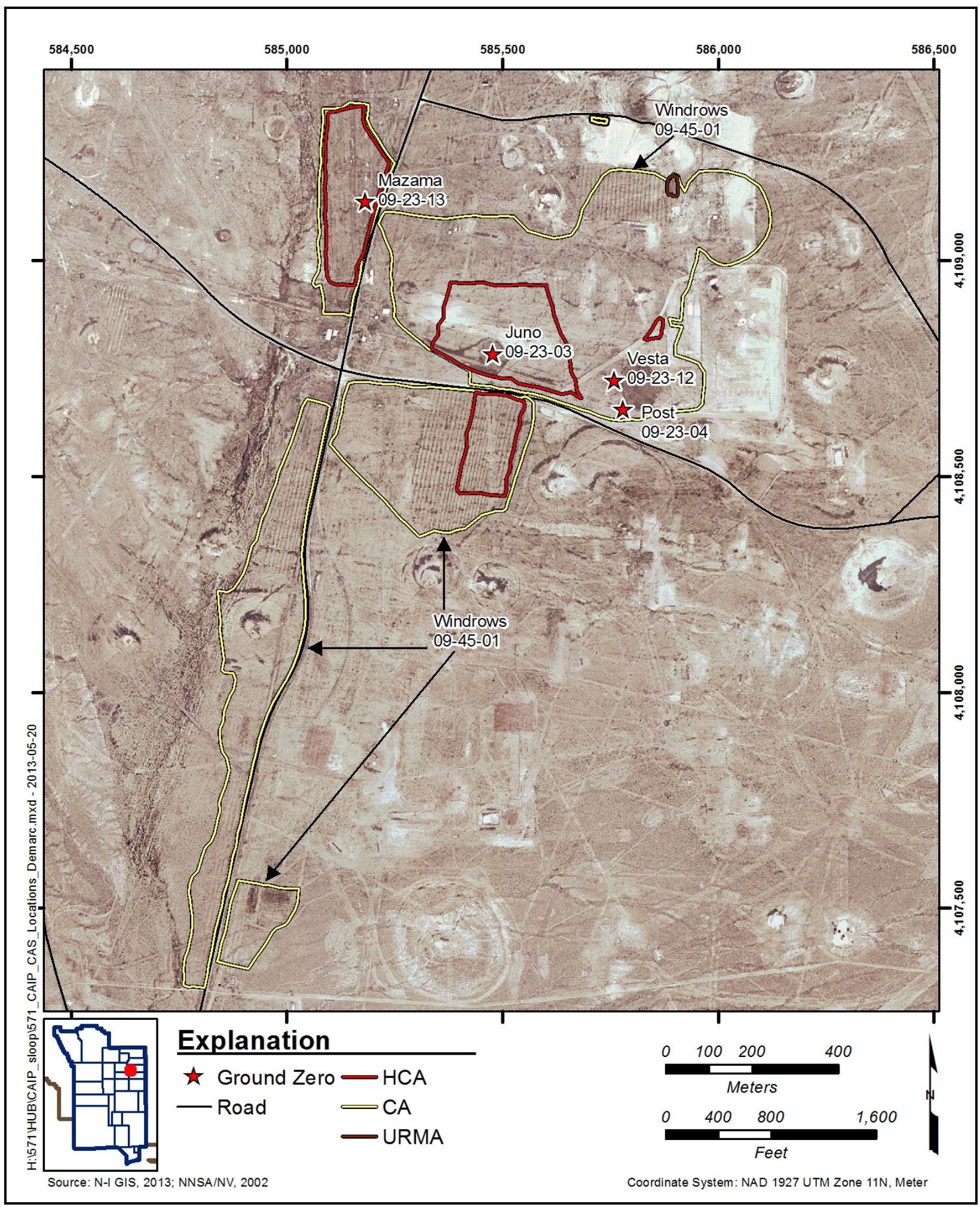

Figure 2-1

CAU 571 CAS Locations and Radiological Demarcations 


\subsubsection{Post (CAS 09-23-04, Atmospheric Test Site T9-C)}

This site is defined as the release of contaminants associated with the Post weapons-related test. Post was conducted on April 9, 1955, as part of Operation Teapot. The test consisted of a primarily plutonium and uranium device that was detonated atop a 300-ft tower. The yield from the test was 2 kilotons (DOE/NV, 2000).

As a result of the Post weapons-related test, unfissioned plutonium and other radioactive material contaminated the area. Because relocation of instrumentation and recording installations would have proved more costly than decontaminating the area, it was determined that a decontamination effort would take place in August 1956. Ground contamination appeared to be radioactive material fused into silica pellets varying in size from microscopic to 1/8 in. Radioactive material was also plated on the metal tower debris (REECo, 1956).

Decontamination of the area began with using a torch to disengage the metal tower debris. Large metal sections were dragged to a contaminated waste dump (CWD) using a bulldozer while smaller sections were loaded onto a dump truck for disposal. After the area was clear of debris, tournapulls assisted with bulldozers scraped the area to be decontaminated to a depth of 4 to 6 in. Contaminated soil was taken to the dump, and fresh soil was brought in and spread in the decontaminated area. Bulldozers and graders then furrowed, harrowed, and leveled the area to turn under any remaining contaminated material. Air samplers and fallout trays were used in the work area and along the dump routes during the decontamination activities (REECo, 1956).

Figure 2-1 shows the Post GZ as well as the current radiological demarcation fence lines. Figure 2-2 is a map from the decontamination report (discussed above) showing the location of the decontaminated areas as well as the CWD. The CWD (known as CWD-9A) was cleaned up in 1985 as part of the radioactive waste consolidation project (REECo, 1985) and, therefore, will not be included in the investigation of CAU 571 (see Section 2.5.1 for details). 


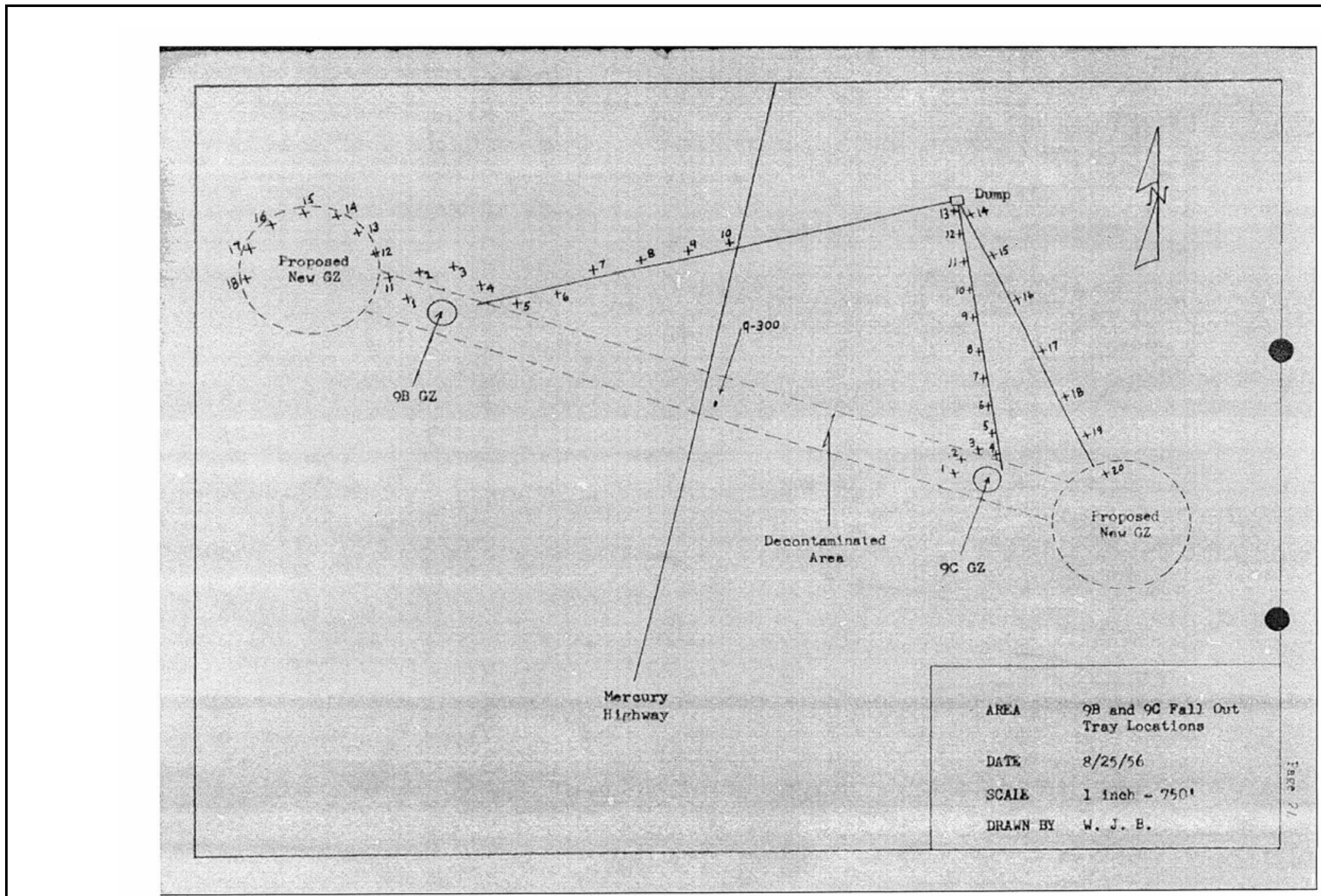

Figure 2-2

Area 9 Decontamination Map - Post

Source: REECo, 1956

\section{UNCONTROLLED When Printed}




\subsubsection{Juno (CAS 09-23-03, Atmospheric Test Site S-9F); Vesta (CAS 09-23-12, Atmospheric Test Site S9-E); Mazama (CAS 09-23-13, Atmospheric Test Site T-9D)}

The tests associated with CASs 09-23-03, 09-23-12, and 09-23-13 were completed within a span of 13 days. After the tests were conducted, a decontamination effort was completed that impacts the current condition of the site. The following describes the individual tests and the decontamination activity:

\section{CAS 09-23-03}

This site is defined as the release of contaminants associated with the Juno safety experiment. Juno was conducted on October 24, 1958, as part of Operation Hardtack II. The test consisted of a primarily plutonium device that was detonated in a blast chamber covered with $20 \mathrm{ft}$ of gravel (known as a "gravel gertie”). The yield from the experiment was 1.7 tons, and a crater measuring 50 to $75 \mathrm{ft}$ deep and $75 \mathrm{ft}$ wide was created as a result of the test. The plume traveled to the south of the GZ (DOE/NV, 2000; REECo, Date Unknown; DNA, 1979).

\section{CAS 09-23-12}

This site is defined as the release of contaminants associated with the Vesta safety experiment. Vesta was conducted on October 17, 1958, as part of Operation Hardtack II. The test consisted of a primarily plutonium and uranium device that was detonated in a gravel gertie covered with $20 \mathrm{ft}$ of gravel. The yield from the experiment was 24 tons, and a crater measuring $50 \mathrm{ft}$ to $75 \mathrm{ft}$ deep and $75 \mathrm{ft}$ wide was created as a result of the test. The plume traveled to the north of the GZ (DOE/NV, 2000; REECo, Date Unknown; DNA, 1979).

\section{CAS 09-23-13}

This site is defined as the release of contaminants associated with the Mazama weapons-related test. Mazama was conducted on October 29, 1958, as part of Operation Hardtack II. The test consisted of a primarily plutonium device that was detonated in a wooden cab atop a 50-ft steel tower. There was no yield (DOE/NV, 2000; REECo, Date Unknown). 
Decontamination Activity of CASs 09-23-03, 09-23-12, and 09-23-13

A decontamination activity took place in 1959 to address the contamination resulting from the Juno, Vesta, and Mazama tests. Washing, removal, and fixation of radioactivity were employed to decontaminate the large impacted area. Washing consisted of a wash-scrub-rinse method that was used on the main access road that ran north-south through the area. The removal method consisted of debris and soil removal from the areas most anticipated for future use. Finally, the fixation method was used in the areas that were to have a limited future use. This method consisted of scraping the contaminated soil into rows that were $2 \mathrm{ft}$ high and $3 \mathrm{ft}$ wide and then spraying the rows with hot road oil. These rows are termed "windrows."

The Mazama tower was dismantled using torches, and the debris was placed in a CWD. The contaminated soil in the area impacted by Mazama was then windrowed in place. The contaminated debris associated with Juno and Vesta was also placed in the CWD (see Section 2.5.1 for details about CWD-9A). After debris removal, the top few inches of contaminated soil surrounding the GZs was placed into the Juno and Vesta detonation craters. The soil in the craters was then covered with clean earth and sealed with road oil. Concrete tower anchors and other small contaminated concrete structures associated with the gravel gerties that impeded the scraping operations were toppled into holes dug near their bases and covered with earth. The remaining contaminated soil within the plumes associated with these two tests was windrowed in place.

Figure 2-1 shows the Juno, Vesta, and Mazama GZs, as well as the current radiological demarcation fence lines. Figure 2-3 shows a map depicting the configuration of the area after decontamination activities were completed (REECo, Date Unknown).

\subsubsection{Windrows (CAS 09-45-01, Windrows Crater)}

As part of the decontamination effort discussed in Section 2.2.2, windrows were created and sprayed with road oil as a method to reduce migration of contamination. Windrows were created at Mazama, to the north and south of Juno and Vesta, and along the southern access road. Figure 2-1 shows the general location of the windrows CAS and the current radiological demarcation fence lines.

Figure 2-3 shows a map depicting the configuration of the area after decontamination activities were completed (REECo, Date Unknown). Subsequent activities in the area, such as underground testing, 


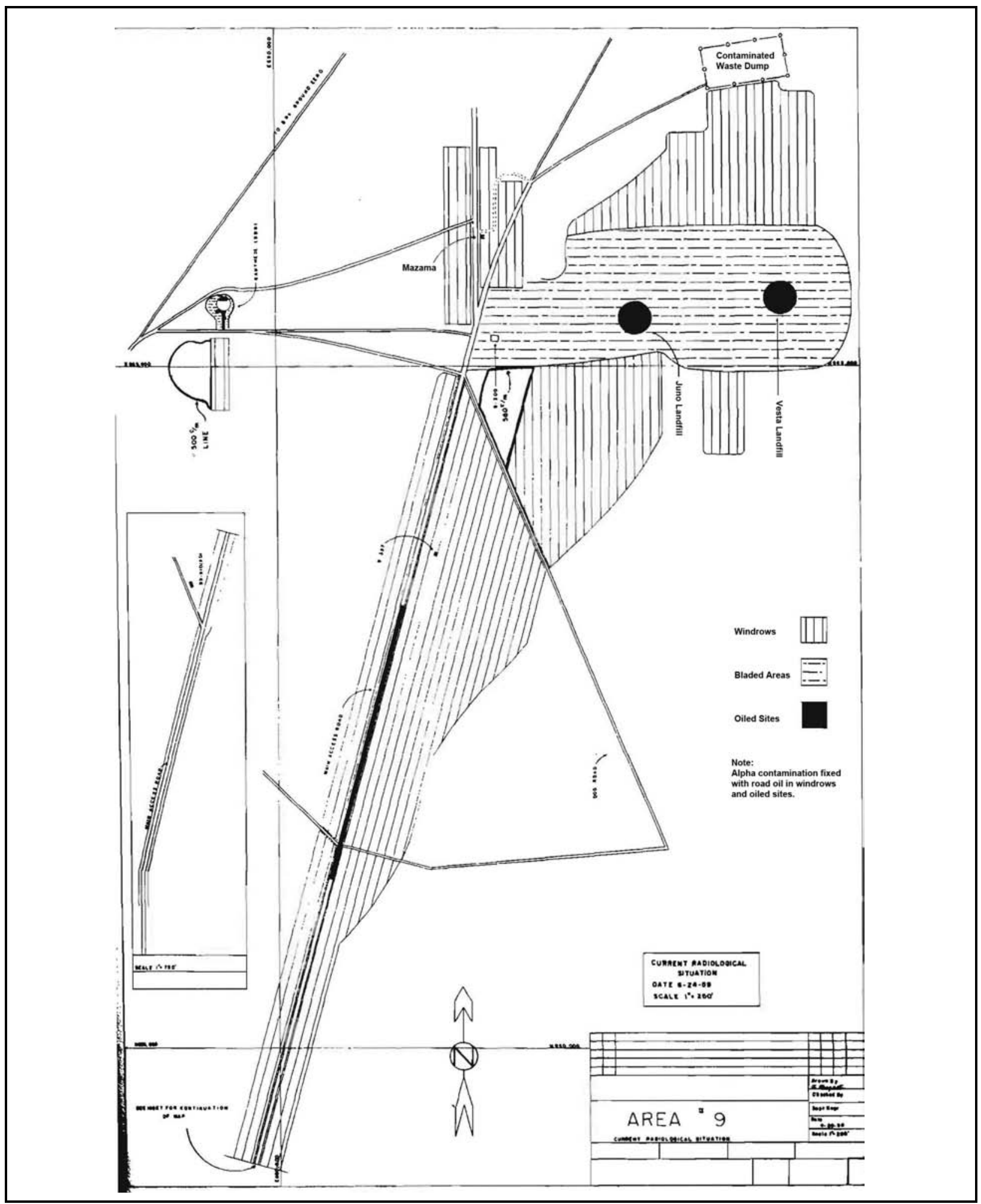

Figure 2-3

Area 9 Decontamination Map - Juno, Vesta, Mazama (1959)

Source: Modified from REECO, Date Unknown 
took place after the formation of the windrows and, as a result, many of the windrows were disturbed and destroyed. Figures 2-4 through 2-6 show the windrows in various stages (REECo, Date Unknown and 1982).

\subsection{Waste Inventory}

Available documentation, process knowledge, and general historical NNSS practices were used to identify wastes that may be present. Solid waste items identified at CAU 571 include various debris such as lead items (e.g., bricks), batteries, drums, grease staining, and tar items. Investigation-derived waste (IDW) may include soil, personal protective equipment (PPE), sampling equipment, decontamination liquids, and debris. Potential waste types include industrial waste, low-level radioactive, hazardous, hydrocarbon, or mixed waste.

\subsection{Release Information}

The releases of contamination to CAU 571 are directly or indirectly associated with four nuclear tests conducted in the area. The investigation of specific releases at CAU 571 will depend upon the nature of these releases. Therefore, the releases at CAU 571 have been categorized into one of the study groups defined in Section 1.1.2.

Exposure routes to receptors include ingestion and inhalation of radionuclides in surface soil (internal exposure). Site workers may also be exposed to direct radiation by performing activities in proximity to radiologically contaminated materials (i.e., external dose). Therefore, the CSM will include the potential for receptors to receive an internal dose from contaminated soil and an external dose from contaminated soil and debris.

The following subsections contain study group-specific descriptions of known or suspected releases associated with CAU 571.

\subsubsection{Study Group 1, Atmospheric Release}

The Study Group 1 release consists of residual fuel and fission products deposited onto surface soils from atmospheric test fallout, including activated soil products and unfissioned nuclear materials, that have not been relocated due to mechanical disturbance (e.g., scraping). Because much of the area in 


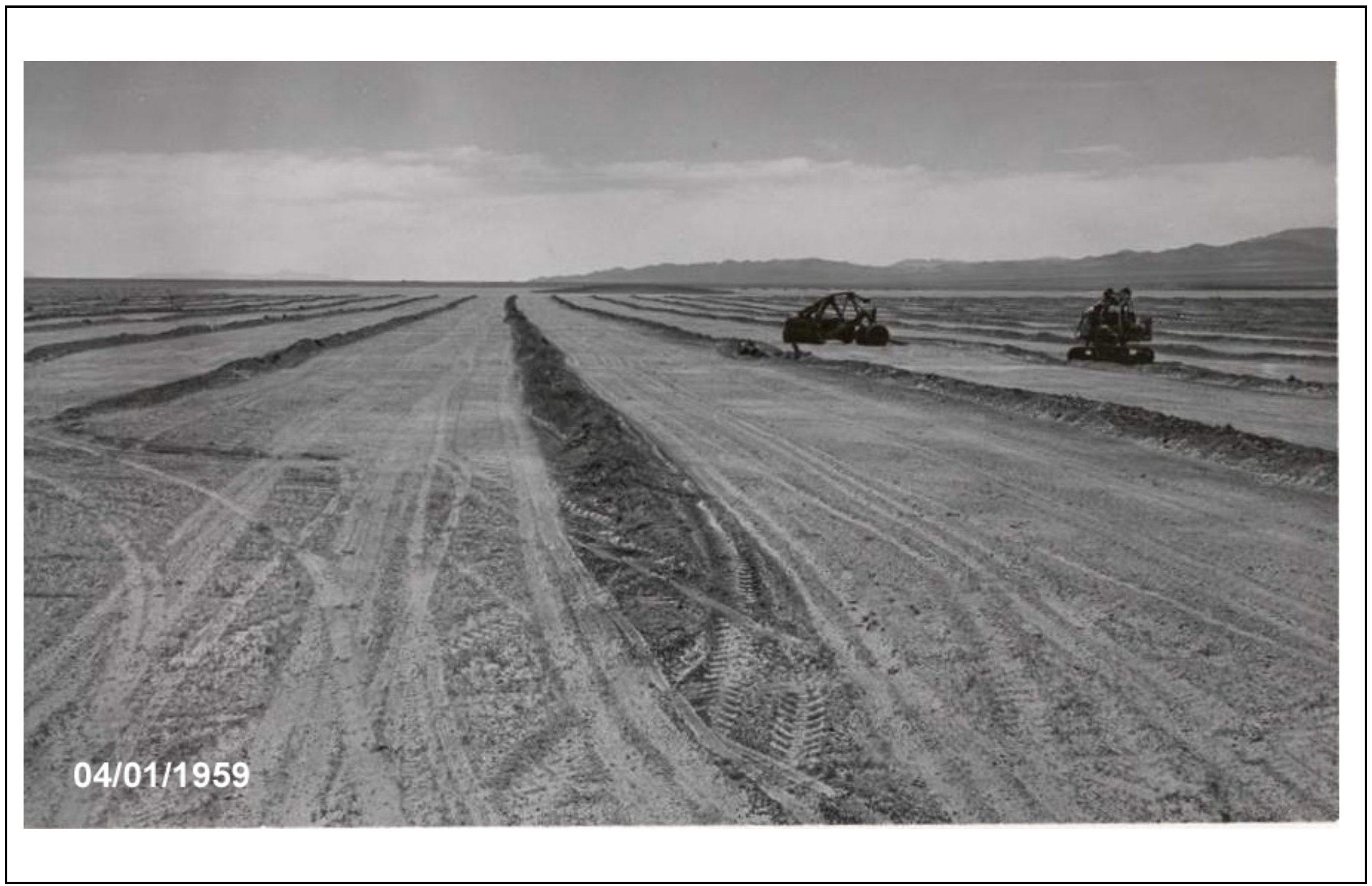

Figure 2-4

Windrows

Source: REECO, 1982

UNCONTROLLED When Printed 


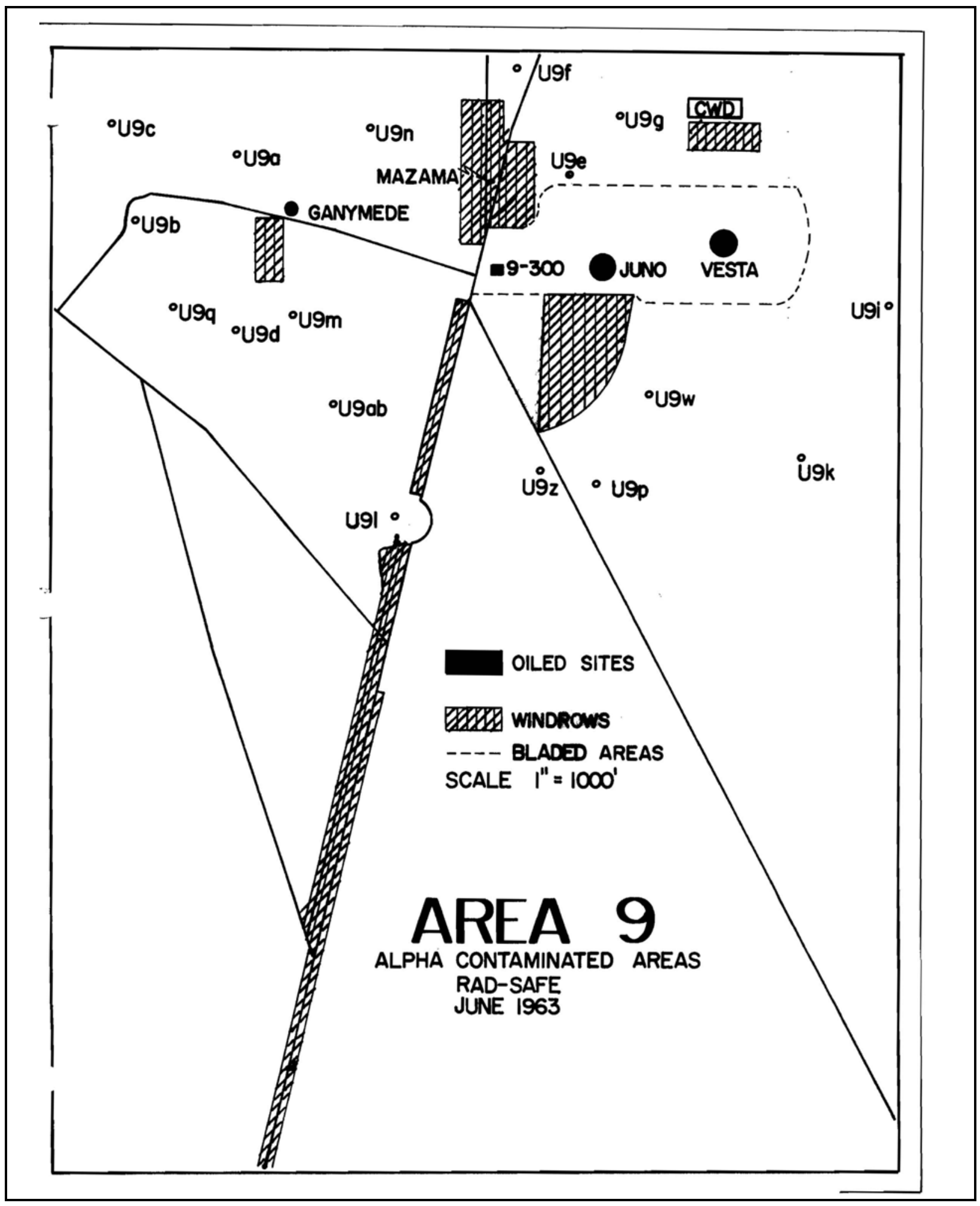

Figure 2-5

Historical Map Showing Windrow Disturbance (1963)

Source: REECO, Date Unknown 


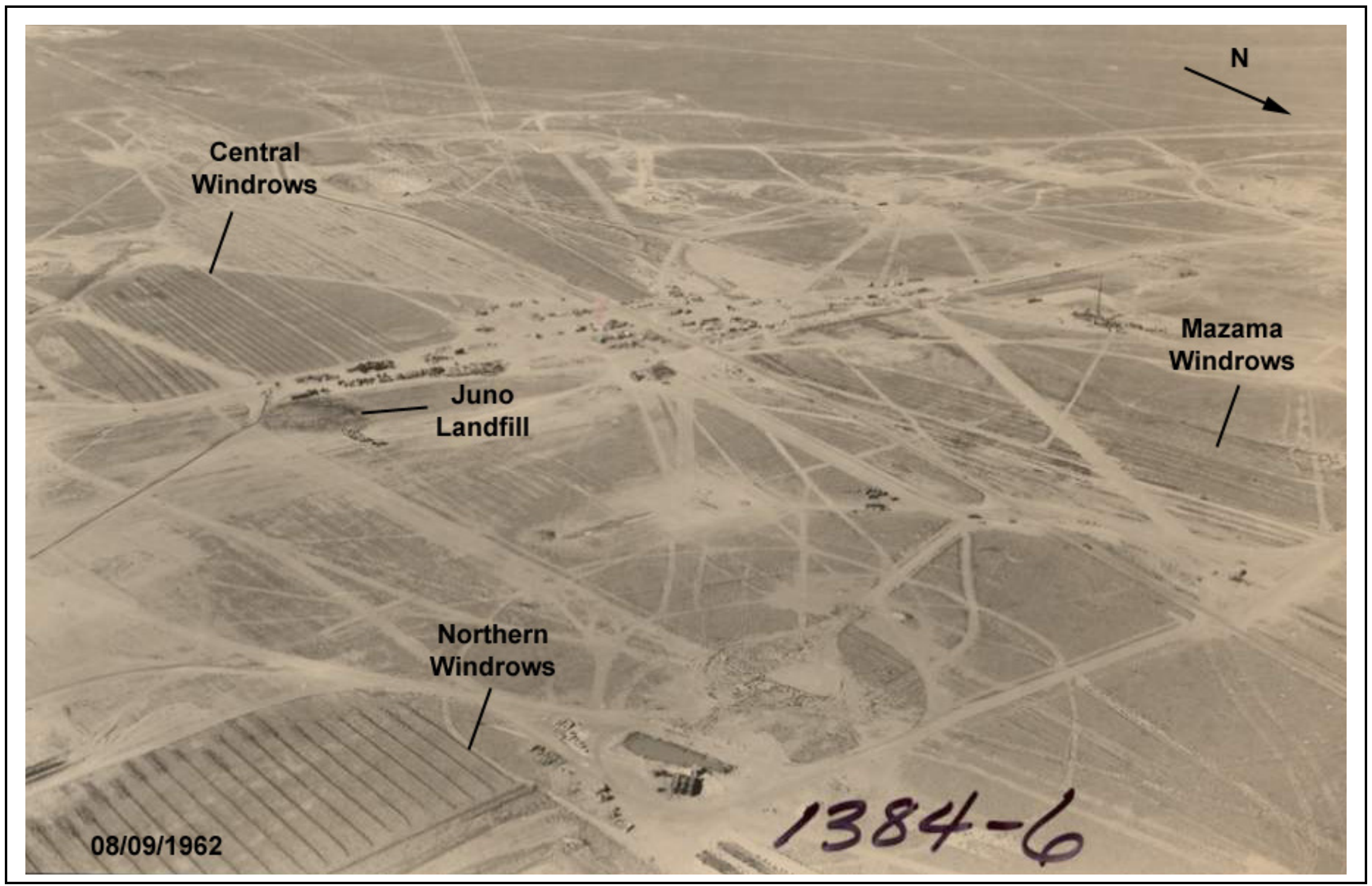

Figure 2-6

Historical Photograph Depicting Windrow and Test Area Disturbance Source: Modified from REECO, 1982 
CAU 571 was disturbed due to decontamination activities after the four tests as well as subsequent underground testing activities, the remaining area impacted by the Study Group 1 release is limited. Historical photographs, maps, and visual surveys were used to determine locations impacted by the Study Group 1 release that remain relatively undisturbed.

The release of radionuclides from the four tests was distributed in roughly concentric patterns on the ground surface, exhibiting a pattern of surface contamination that is generally decreasing in concentration with increasing distance from the release locations.

\subsubsection{Study Group 2, Subsurface Contamination}

The Study Group 2 release consists of residual fuel and fission products deposited onto surface soils from fallout, including activated soil products and unfissioned nuclear materials, that have subsequently been relocated and/or covered due to mechanical means. The decontamination activities that took place after the tests were conducted resulted in soil being scraped, leveled, furrowed, and covered. Additionally, subsequent underground test activities took place in close proximity to the test areas that further disturbed the original atmospheric release being addressed by Study Group 1 and resulted in potential buried contamination. Therefore, contamination is potentially present at depths greater than $5 \mathrm{~cm}$ bgs. Historical photographs, maps, and visual surveys were used as a guide to determine the area that has been extensively disturbed (Study Group 2) versus the area that was relatively undisturbed (Study Group 1).

\subsubsection{Study Group 3, Windrows}

The Study Group 3 release consists of radionuclide contamination that was initially deposited onto the soil from the atmospheric releases but subsequently scraped into windrows. The investigation will also address potential chemical contamination associated with the road oil that was applied to the windrows to reduce radionuclide contaminant migration. Historical photographs, maps (specifically, Figure 2-3), and visual surveys were used to guide the selection of the Study Group 3 boundary. Windrows are still in their original form both north and south of Juno and Vesta, in the Mazama test area, and along the access road. Some of these windrows have been disturbed, but these areas are still included in the Study Group 3 boundary. The study group has been defined as distinct areas as discussed in Section 4.2.2.3 and outlined in Table 4-1. 


\subsubsection{Study Group 4, Drainage}

The Study Group 4 release consists of contamination migration, which includes the relocation of contamination into sedimentation areas due to stormwater runoff. Visual surveys were used to identify the location of the drainage.

\subsubsection{Study Group 5, Other}

Study Group 5 consists of releases associated with PSM, an asphalt pile, and a radiologically posted contamination area (CA). There may be a release of chemical COCs to surface and shallow subsurface soil from lead bricks, batteries, drums, spills, and other debris at CAU 571. An asphalt pile may also be another source of chemical COC release to surface soil. Additionally, a radiologically posted CA was identified during a terrestrial radiological survey (see Sections 2.5.2.2 and 2.5.4) and

will require investigation. This CA consists of a release of radionuclides to surface soil from test and decontamination activities associated with CAU 571. Visual surveys and terrestrial radiological surveys were used to identify the location of the debris and other features of interest. If additional features not associated with Study Groups 1 through 4 requiring investigation are discovered during the CAI, they will be addressed in Study Group 5.

\subsection{Investigative Background}

All previous investigation data are assessed in the planning phase to identify bias used in the selection of appropriate sampling locations. The following subsections summarize pertinent historical documentation as well as additional investigations conducted at CAU 571.

\subsubsection{Area 9 Waste Consolidation}

Site 9A (also known as CWD-9A) was a 300-by-560-ft fenced area containing approximately 6,200 cubic yards $\left(\mathrm{yd}^{3}\right)$ of dirt mounds, $250 \mathrm{yd}^{3}$ of concrete debris, 175 tons of steel and cable, and 1,000 board-feet of lumber. All activities planned for cleanup were accomplished. Approximately $30,000 \mathrm{yd}^{3}$ of contaminated material was moved from Site 9A to the U3axbl RWMS. Cleanup was started in 1984 and completed in 1985 (REECo, 1985). 
Site 9A is the contaminated waste dump that was used to dispose of soil and debris from all four tests investigated in CAU 571. The soil piles with debris that remain on the east side of the pit were addressed in CAU 137, CAS 09-23-07. Removable contamination requiring a CA radiological posting was identified in an area west of the former waste dump. This CA will be investigated in CAU 571 in Study Group 5. The remainder of the former CWD will not be investigated in CAU 571.

\subsubsection{Radiological Surveys}

Aerial and terrestrial radiological surveys were completed at CAU 571. In accordance with the graded approach described in the Soils QAP (NNSA/NSO, 2012b), the quality required of a dataset will be determined by its intended use in decision making. Terrestrial and aerial radiological survey data are classified as decision supporting and are not used, by themselves, to make corrective action decisions. However, the radiation surveys are used to identify bias used in the selection of sample locations and will be evaluated for use in defining corrective action boundaries in the investigation report. For defining corrective action boundaries, the radiation surveys will be used only in terms of defining a relative spatial distribution of contamination.

Table 2-2 lists the method descriptions, advantages, limitations, spatial and spectral resolutions, measurement dates, and applied use for the different radiation surveys that were selected for use in developing the investigation for CAU 571. The surveys are not comprehensive, and additional surveys will be required.

\subsubsection{Americium-241 and Man-made Aerial Radiological Flyover Surveys (2012)}

The aerial radiation surveys provide spectral information that was used to differentiate specific isotopic signatures. This allows the separate mapping of americium (Am)-241 contamination and man-made gamma activity within the surveyed areas. The presence of Am-241 is used as an indicator of the potential presence of plutonium contamination. In April 2012, aerial radiological flyover surveys were conducted at the NNSS to characterize the radiation exposure. The surveys were conducted in portions of Area 9 by flying along a set of parallel flight lines spaced approximately $75 \mathrm{ft}$ apart at $50 \mathrm{ft}$ above ground level. The purpose of the surveys was to measure, map, and define the areas of man-made radiation as well as Am-241 activity to determine the areas of plutonium 
Table 2-2

\section{Comparison of Radiation Survey Methods}

\begin{tabular}{|c|c|c|c|}
\hline & FIDLER & PRM-470 & Aerial Radiological Survey \\
\hline $\begin{array}{l}\text { Method } \\
\text { Description } \\
\text { Summary }\end{array}$ & $\begin{array}{l}\text { Ground-based instrument that } \\
\text { detects low-energy } \\
\text { gamma emissions }\end{array}$ & $\begin{array}{l}\text { Ground-based organic plastic } \\
\text { scintillator instrument that } \\
\text { detects gamma emissions }\end{array}$ & $\begin{array}{l}\text { Helicopter-mounted } \\
\text { thallium-activated sodium iodide, } \\
\text { gamma-ray scintillation detectors }\end{array}$ \\
\hline $\begin{array}{l}\text { Advantages } \\
\text { and Limitations }\end{array}$ & $\begin{array}{l}\text { Advantages: Lightweight } \\
\text { hand-held instrument designed } \\
\text { to see low-energy } \\
\text { gamma emissions. } \\
\text { Limitations: Does not } \\
\text { discriminate between low energy } \\
\text { gamma emissions from } \\
\text { different isotopes. }\end{array}$ & $\begin{array}{l}\text { Advantages: Lightweight } \\
\text { hand-held instrument that } \\
\text { detects gamma emissions. } \\
\text { Limitations: Does not distinguish } \\
\text { between the radionuclides } \\
\text { emitting the gamma emissions. }\end{array}$ & $\begin{array}{l}\text { Advantages: Gives a wide area } \\
\text { of view (as opposed to } \\
\text { ground-based surveys); can } \\
\text { survey large areas quickly. } \\
\text { Limitations: Because it is } \\
\text { elevated and moving at a fast } \\
\text { rate, does not distinguish small } \\
\text { localized areas of } \\
\text { contamination or materials that } \\
\text { are contaminated. }\end{array}$ \\
\hline Spatial Resolution & $\begin{array}{l}\text { Held at } \sim 6 \text { in. above ground } \\
\text { surface, has a small field of view. }\end{array}$ & $\begin{array}{l}\text { Held at } \sim 1 \mathrm{~m} \text { above ground } \\
\text { surface, has a small field of view. }\end{array}$ & $\begin{array}{l}\text { Altitude: } 50 \mathrm{ft} \\
\text { Line Spacing: } \sim 75 \mathrm{ft}\end{array}$ \\
\hline Spectral Resolution & 10 to $100 \mathrm{keV}$ & All gamma emitters & 38 to $3,026 \mathrm{keV}$ \\
\hline Measurement Date & 2011 and 2013 & April 2013 & April 19 and April 25, 2012 \\
\hline $\begin{array}{l}\text { Applied } \\
\text { Use }\end{array}$ & $\begin{array}{l}\text { Energies in the } 59-\mathrm{keV} \text { range, } \\
\text { which are indicative of Am-241 or } \\
\text { other higher-energy emitters; } \\
\text { used to identify Am-241 } \\
\text { contamination as an indicator of } \\
\text { plutonium contamination }\end{array}$ & $\begin{array}{l}\text { Nondiscriminatory gamma count } \\
\text { used to identify contamination } \\
\text { from nuclear testing }\end{array}$ & $\begin{array}{l}\text { For } A m-241 \text { : Processed for } \\
\text { energies in the } 57-\text { to } 70-k e V \\
\text { range (Am-241) relative to the } \\
38-\text { to } 50-k e V \text { and } 70-\text { to } 82-k e V \\
\text { background windows. Used to } \\
\text { identify Am-241 contamination as } \\
\text { an indicator of plutonium } \\
\text { contamination. } \\
\text { For man-made: Processed for } \\
\text { energies in the 38- to } 1,294-k e V \\
\text { window relative to the } 1,394-\text { to } \\
3,026-k e V \text { background window. } \\
\text { Used to identify contamination } \\
\text { from nuclear testing. }\end{array}$ \\
\hline
\end{tabular}

Source: N-I GIS, 2013; NSTec, 2012; Riedhauser, 1999; Buchheit and Marianno, 2005; TSA Systems, 2005

FIDLER = Field instrument for the detection of low-energy radiation

$\mathrm{keV}=$ Kiloelectron volt

$\mathrm{m}=$ Meter

contamination. Both surveys were reviewed to assess the levels of radiological contamination in this area occurring as a result of the four atmospheric tests and the four underground tests that vented.

Figures 2-7 and 2-8 show the results of the 2012 Am-241 and man-made aerial radiological surveys. Concentrations of Am-241 are centered around the Juno and Vesta GZs, which are now the location of buried contamination scraped and compiled in the two detonation craters. Additionally, there is an Am-241 signature at the Mazama GZ. There are no elevated readings at any of the underground test locations. 


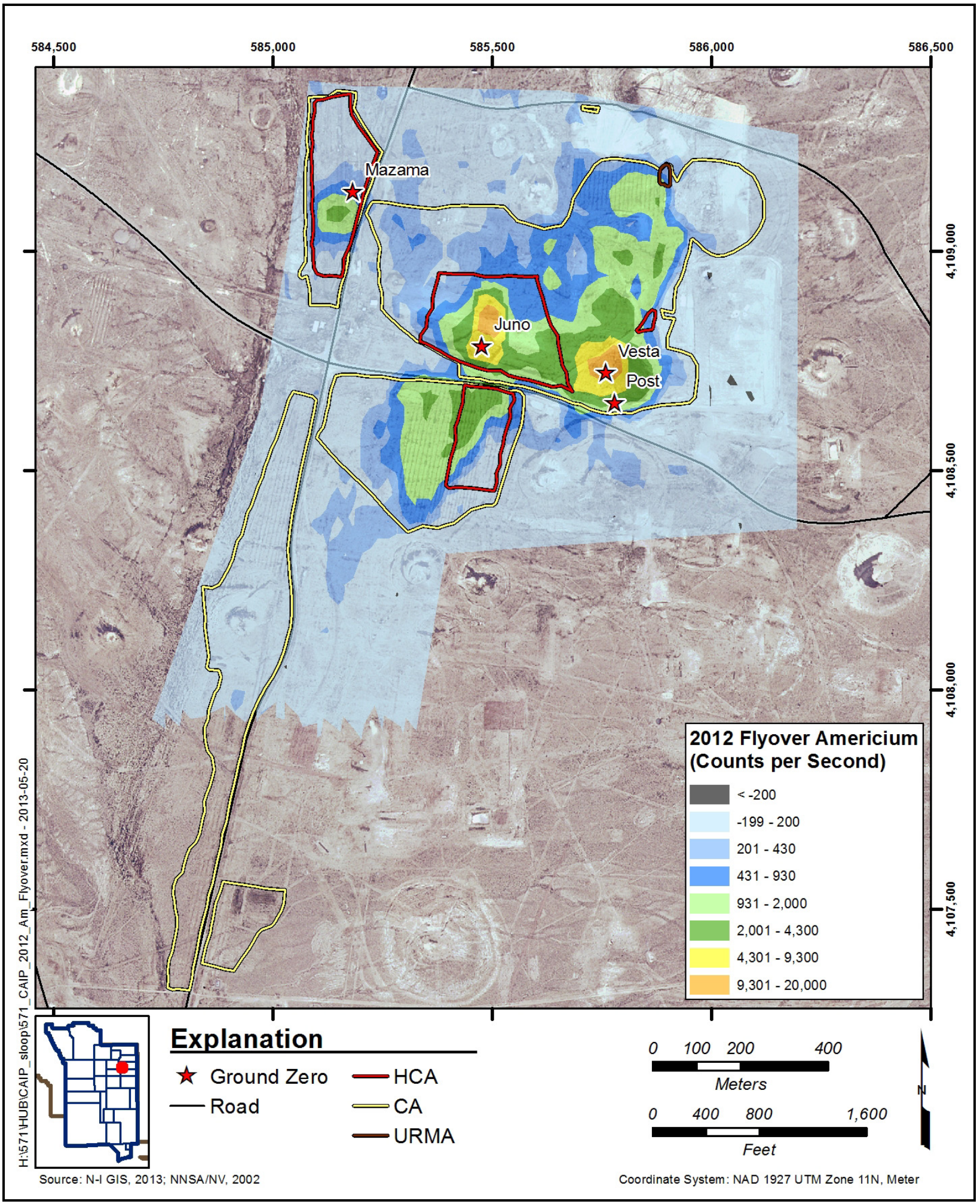

Figure 2-7

CAU 571 Am-241 Aerial Data 


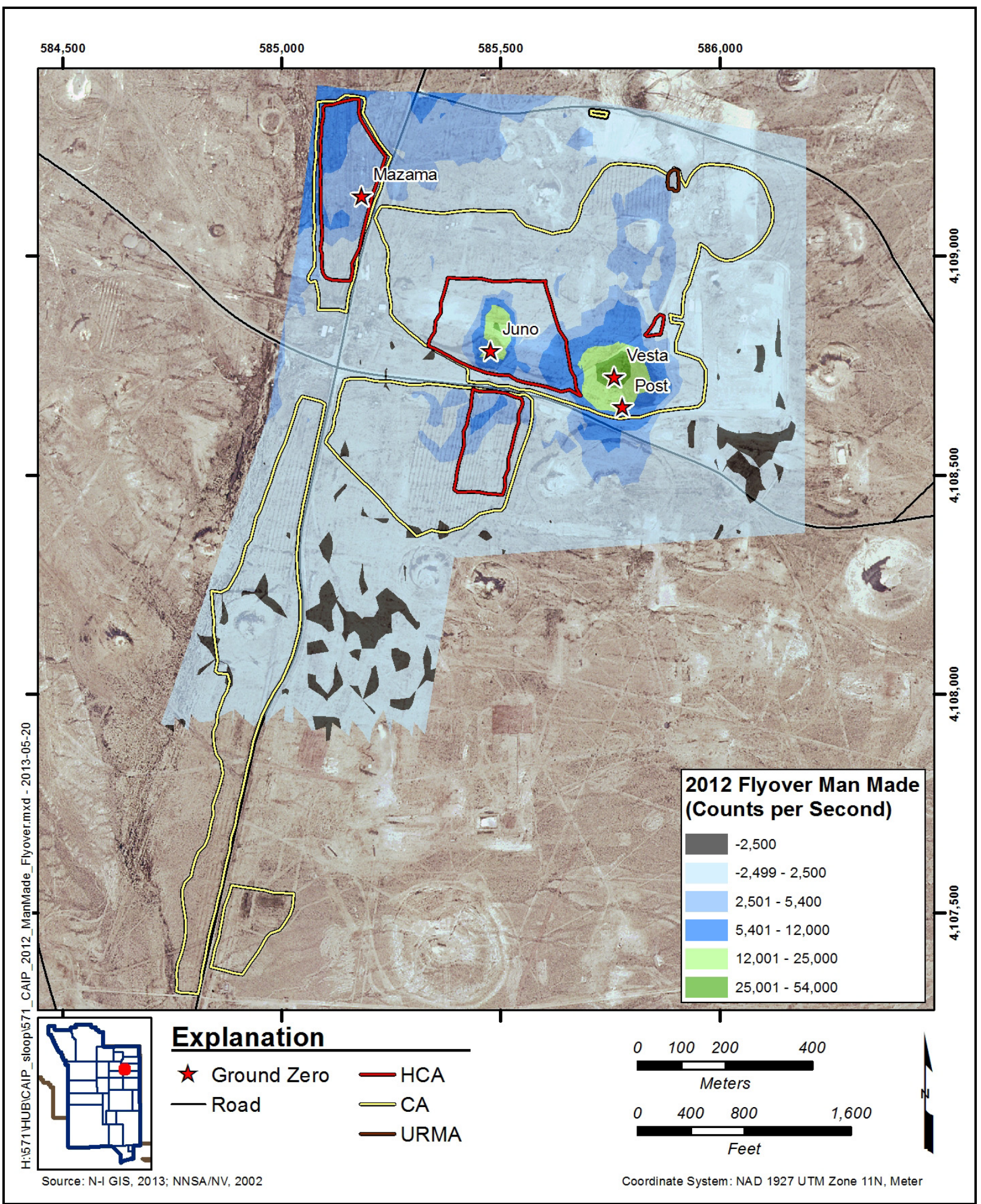

Figure 2-8

CAU 571 Man-Made Aerial Data 
Previous aerial surveys completed of the CAU 571 test area were not as accurate and, therefore, are not discussed. The surveys completed in 2012 will be referenced and used as a tool to select biased, elevated radiological sample locations.

\subsubsection{Terrestrial Radiological Surveys}

Terrestrial radiological surveys were conducted outside the HCAs and in areas identified during the preliminary investigation to be a concern. This included areas impacted by the test plumes (including releases from underground tests) and where windrows were created. Because plutonium has been identified as the primary constituent of concern, it was determined that the FIDLER instrument would be used to complete the terrestrial radiological survey as it would provide the most appropriate and useful data for the Juno and Vesta plumes. The highest radiological readings obtained thus far are located west of the Vesta landfill. An area with elevated removable contamination was identified west of the former CWD-9A. Because this area did not have a radiological posting, the area was appropriately posted as a CA. Figure 2-9 shows the locations where the FIDLER terrestrial radiological surveys were completed and the results of the survey. The survey results are presented in units of counts per second (cps) and evaluated qualitatively as comparative relative spatial distributions in units of multiples of background.

Because there was a yield at Post and it was a weapons-related test, a survey using the PRM-470 was completed in the areas most likely to be impacted, although the area has been decontaminated and subsequently covered by the Vesta test. The PRM-470 did not show any areas of significantly elevated gamma activity that was not previously identified by the FIDLER. Therefore, only the FIDLER results are reported and will be used to select biased sample locations.

\subsubsection{Radionuclide Inventory and Distribution Program}

The Radionuclide Inventory and Distribution Program (RIDP) conducted an investigation from 1981 through 1986 that estimated the inventory of man-made radionuclides at the NNSS through in situ gamma spectroscopy (McArthur and Mead, 1987). The RIDP data at CAU 571 is shown on Figure 2-10. The highest levels of plutonium (Pu)-239 are located adjacent to the western side of the Vesta landfill and within the HCA-posted windrows south of Vesta. This is consistent with the distribution pattern found in the Am-241 aerial radiological survey (Section 2.5.2.1) and the 


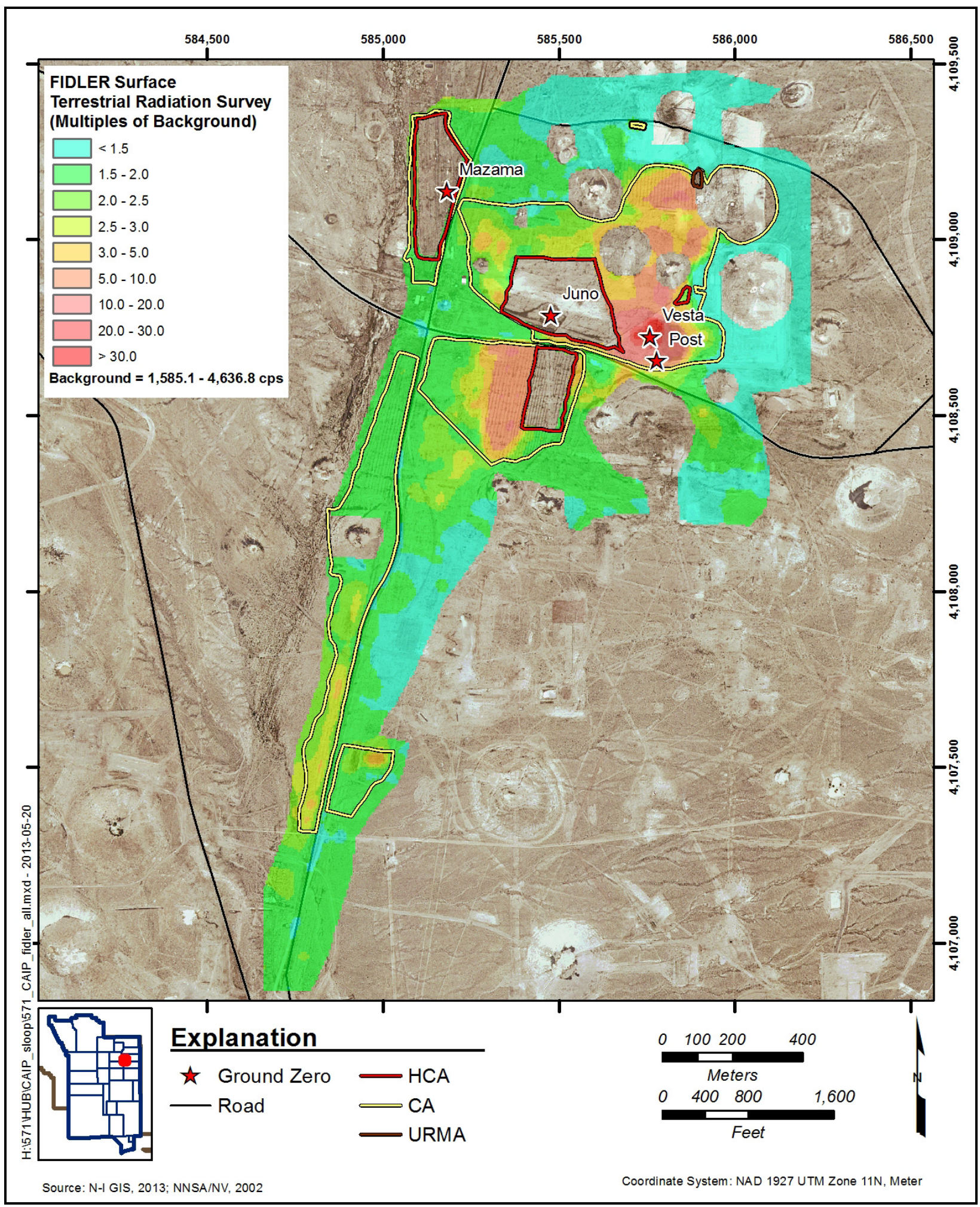

Figure 2-9

CAU 571 FIDLER Survey Results 
terrestrial radiological survey (Section 2.5.2.2). RIDP data are provided as they are a part of the background information used during the DQO process as discussed in Appendix A. Although the RIDP data present a general distribution of contamination, there is not sufficient resolution to provide bias in selecting sample locations within CAU 571. In accordance with the graded approach described in the Soils QAP (NNSA/NSO, 2012b), RIDP data are classified as informational and do not directly affect DQOs, but provide information to support conceptual models and guide investigations.

\subsubsection{Preliminary Field Investigation}

In 2012 and 2013, a preliminary field investigation was completed at CAU 571. This effort included terrestrial radiological surveys (Section 2.5.2.2) and visual surveys. During the visual survey, the investigation area was walked over; photographs were taken; debris was documented; and site conditions were noted.

The location of the Juno and Vesta landfills were identified. These landfills represent the soil contamination and debris that was scraped into the two detonation craters during the 1959 decontamination effort (Section 2.2.2). The Juno landfill is located within an HCA. Both landfills are located within a large CA. The Mazama windrows as well as the windrows located north and south of the Juno and Vesta test areas were visually surveyed. It was noted that while some windrows exist, much of the original windrowed areas have been disturbed. Portions of the windrows are within HCAs, CAs, and in areas that are not radiologically posted. There are several craters, mud pits, drill pads, and other features throughout the test area (see Section 2.5.5). Additionally, a posted underground radioactive material area (URMA) containing a soil pile and a CA (identified during the terrestrial radiological surveys) west of the former CWD-9A were noted. Various types of debris (e.g., lead bricks, batteries, drums) and stains were identified that will be investigated as PSM. A small, man-made drainage located on the south side of 9-01 Road was documented.

The visual survey was used to assess the boundaries between Study Groups 1, 2, and 3. Because much of the original atmospheric release area was disturbed, a boundary was established between the relatively undisturbed areas (Study Group 1) and the highly disturbed areas (Study Group 2). Additionally, the visual survey, historical maps, and photographs were used to delineate the original windrows areas (Study Group 3). Figure 2-11 shows the boundaries of the three study groups. 


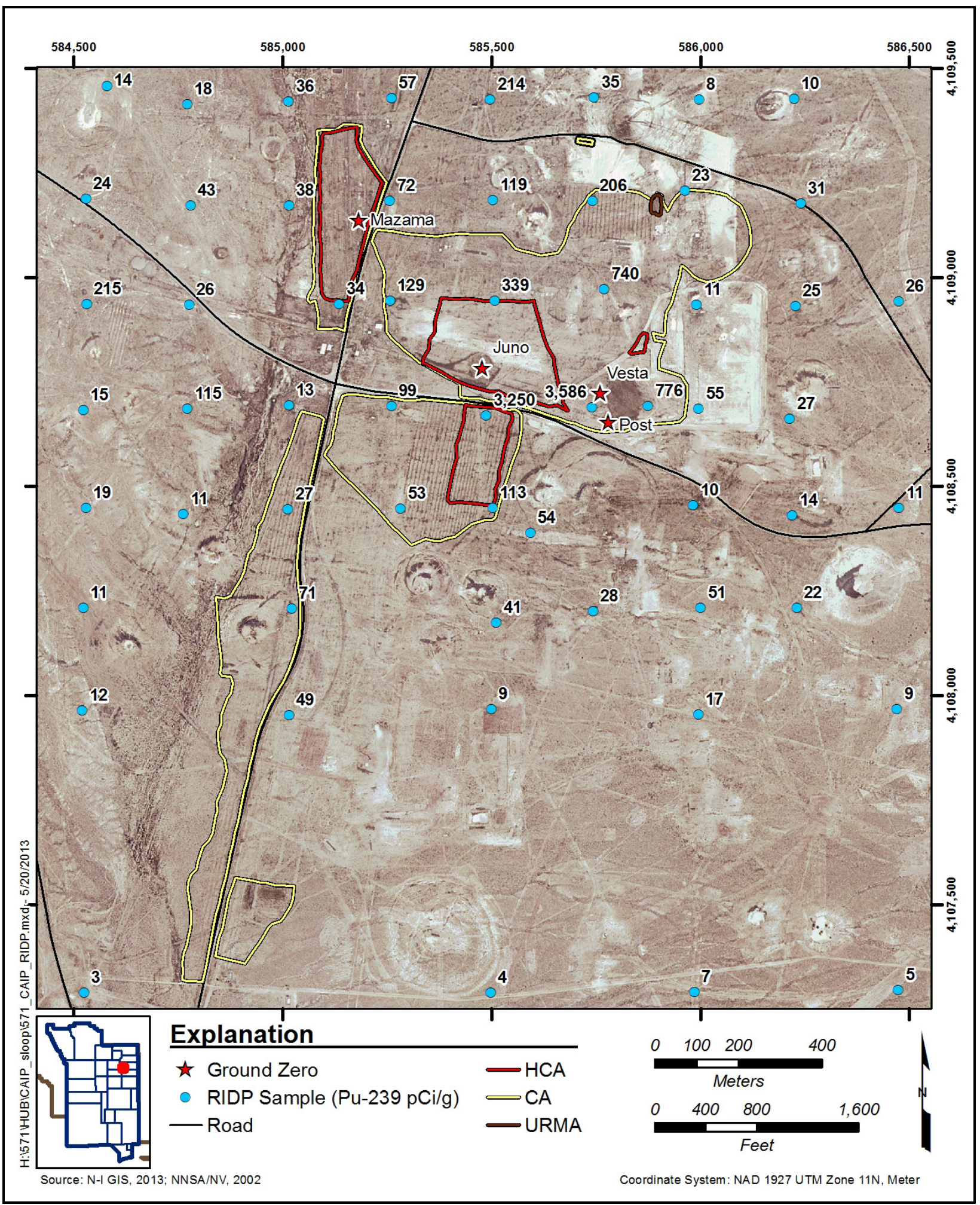

Figure 2-10

CAU 571 RIDP Data 


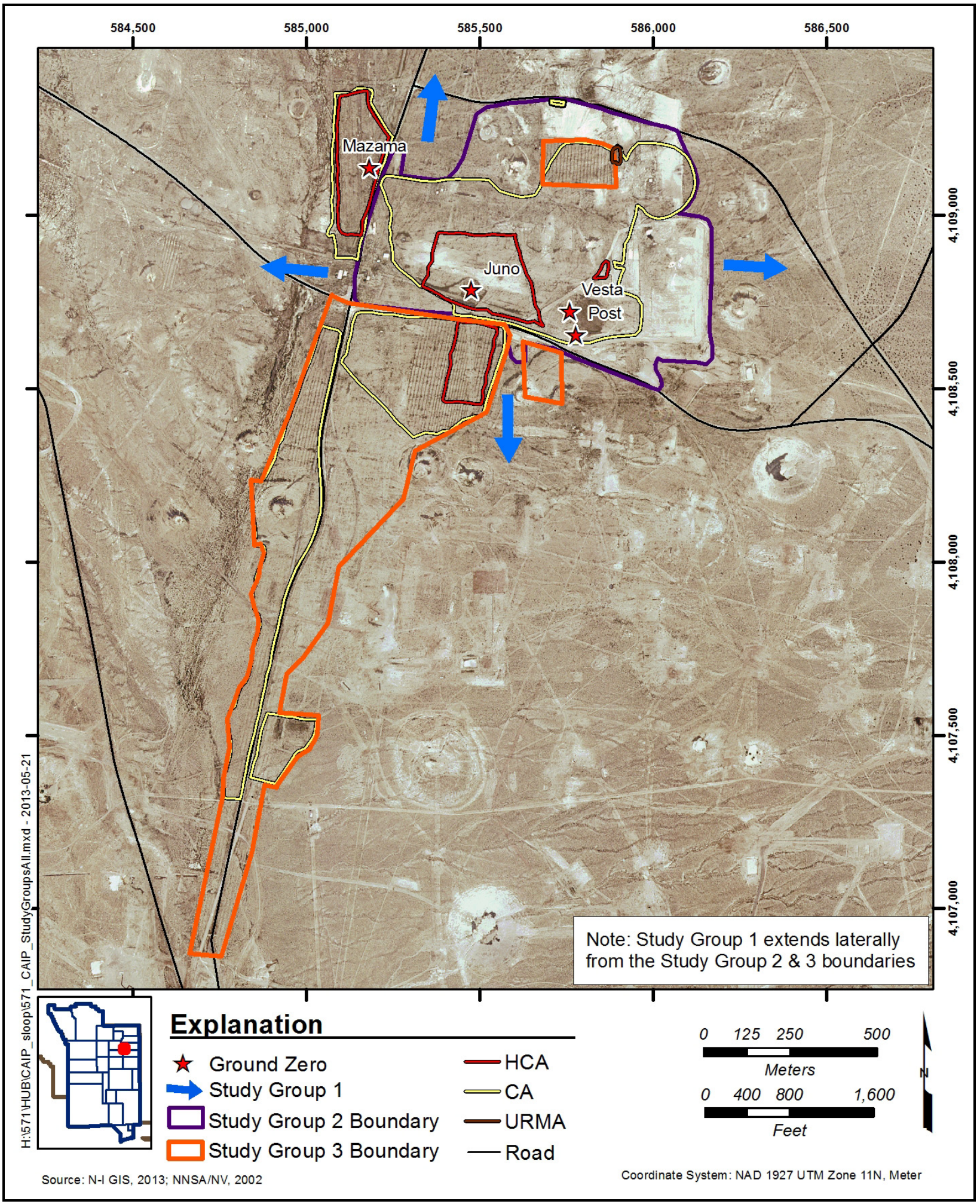

Figure 2-11

CAU 571 Study Group Boundaries 


\subsubsection{Adjacent Investigations}

Numerous CASs are adjacent to the investigation area for CAU 571. Many of these CASs are associated with underground tests that were conducted after the Post, Juno, Vesta, and Mazama tests. These CASs include four underground tests that vented. The aerial radiological flyover survey results were reviewed, and terrestrial radiological walkover survey results confirmed there is no impact to CAU 571 from venting associated with underground testing in the area. Other CASs include mud pits that supported the drilling of underground test holes; miscellaneous housekeeping sites (wax and material piles, asbestos, drums, transformer, and lead brick); a nearby bunker; UST; and other items All of the CASs except the underground test CASs have been investigated. Soil piles with debris that remain on the east side of the CWD-9A were addressed in CAU 137, CAS 09-23-07. The closure strategy associated with each surface CAS or with each subsurface CAS that vented is summarized in Table 2-3.

Table 2-3

CASs Surrounding CAU 571

(Page 1 of 2)

\begin{tabular}{|c|c|c|c|c|}
\hline CAU & CAS No. & CAS Description & Functional Category & Closure Strategy \\
\hline 97 & 09-57-039 & U-9ar Cavity & Underground Test/Detonation Cavity & Close In Place \\
\hline 97 & $09-57-045$ & U-9ay Cavity & Underground Test/Detonation Cavity & Close In Place \\
\hline 97 & 09-57-095 & U-9g Cavity & Underground Test/Detonation Cavity & Close In Place \\
\hline 97 & $09-57-111$ & U-9w Cavity & Underground Test/Detonation Cavity & Close In Place \\
\hline 137 & 09-23-07 & $\begin{array}{l}\text { Radioactive Waste } \\
\text { Disposal Site }\end{array}$ & Rad Contamination Area & No Further Action \\
\hline 139 & 09-34-01 & $\begin{array}{c}\text { Underground Detection } \\
\text { Station }\end{array}$ & Magazine/Bunker & No Further Action \\
\hline 345 & $09-22-03$ & Drum & Housekeeping Waste & Clean Closure \\
\hline 380 & $09-27-01$ & Transformer & Housekeeping Waste & Clean Closure \\
\hline 382 & $09-22-06$ & Drum & Housekeeping Waste & Clean Closure \\
\hline 390 & $09-99-03$ & Wax, Paraffin & Housekeeping Waste & Clean Closure \\
\hline 464 & $09-02-01$ & UST 9-300-1 & Underground Storage Tank & Clean Closure \\
\hline 532 & 09-09-09 & U-9sS Mud Pit (2) & Mud Pit & No Further Action \\
\hline 532 & 09-09-11 & $\begin{array}{c}\text { U-9bi \#2 Zero Station } \\
\text { Mud Pit (2) }\end{array}$ & Mud Pit & No Further Action \\
\hline 532 & $09-09-22$ & U-9cp Mud Pit (1) & Mud Pit & No Further Action \\
\hline 533 & $09-09-26$ & $\begin{array}{c}\text { U-9cv PS \#1A Covered } \\
\text { Mud Pit (1) }\end{array}$ & Mud Pit & No Further Action \\
\hline
\end{tabular}


Table 2-3

\section{CASs Surrounding CAU 571}

(Page 2 of 2)

\begin{tabular}{|c|c|c|c|c|}
\hline CAU & CAS No. & CAS Description & Functional Category & Closure Strategy \\
\hline \hline 533 & $09-09-30$ & U-9k PS \#1 Mud Pit (1) & Mud Pit & Mud Pit Further Action \\
\hline 533 & $09-09-35$ & $\begin{array}{c}\text { U-9bi \#1 PS \#1A } \\
\text { Mud Pit (1) }\end{array}$ & Miscellaneous & Close in Place \\
\hline 547 & $09-99-06$ & Gas Sampling Assembly & Housekeeping Waste & Clean Closure \\
\hline 548 & $09-99-02$ & Material Piles (2) & Housekeeping Waste & Clean Closure \\
\hline 548 & $09-99-04$ & Wax, Paraffin & Housekeeping Waste & Clean Closure \\
\hline 548 & $09-99-05$ & Asbestos, Vermiculite &
\end{tabular}

\subsubsection{National Environmental Policy Act}

The Final Environmental Impact Statement for the Nevada Test Site and Off-Site Locations in the State of Nevada (DOE/NV, 1996) includes site investigation activities such as those proposed for CAU 571.

In accordance with the NNSA/NFO National Environmental Policy Act (NEPA) Compliance Program, a NEPA checklist will be completed before site investigation activities begin at CAU 571. This checklist requires NNSA/NFO activity personnel to evaluate their proposed activities against a list of potential impacts that includes, but are not limited to, air quality, chemical use, waste generation, noise level, and land use. Completion of the checklist results in a determination of the appropriate level of NEPA documentation by the NNSA/NFO NEPA Compliance Officer. This will be accomplished before the field investigation is mobilized. 


\subsection{Objectives}

This section presents an overview of the DQOs for CAU 571 and formulation of the CSM. Also presented is a summary listing of the contaminants of potential concern (COPCs), the preliminary action levels (PALs), and the process used to establish FALs. Additional details and figures depicting the CSM are located in Appendix A.

\subsection{Conceptual Site Model}

The CSM describes the most probable scenario for current conditions at each site and defines the assumptions that are the basis for identifying the future land use, contaminant sources, release mechanisms, migration pathways, exposure points, and exposure routes. The CSM was used to develop appropriate sampling strategies and data collection methods. The CSM was developed for CAU 571 using information from the physical setting, potential contaminant sources, release information, historical background information, knowledge from similar sites, and physical and chemical properties of the potentially affected media and COPCs. Figure 3-1 depicts a representation of the conceptual pathways to receptors from CAU 571 sources. Figure 3-2 depicts a graphical representation of the CSM. If evidence of contamination that is not consistent with the presented CSM is identified during investigation activities, the situation will be reviewed, the CSM will be revised, the DQOs will be reassessed, and a recommendation will be made as to how best to proceed. In such cases, decision makers listed in Section A.2.1 will be notified and given the opportunity to comment on and/or concur with the recommendation.

The following subsections discuss future land use and the identification of exposure pathways (i.e., combination of source, release, migration, exposure point, and receptor exposure route) for CAU 571.

\subsubsection{Land-Use and Exposure Scenarios}

Land-use zones where the CAU 571 sites are located dictate future land use, and restrict current and future land use to nonresidential (i.e., industrial) activities. 


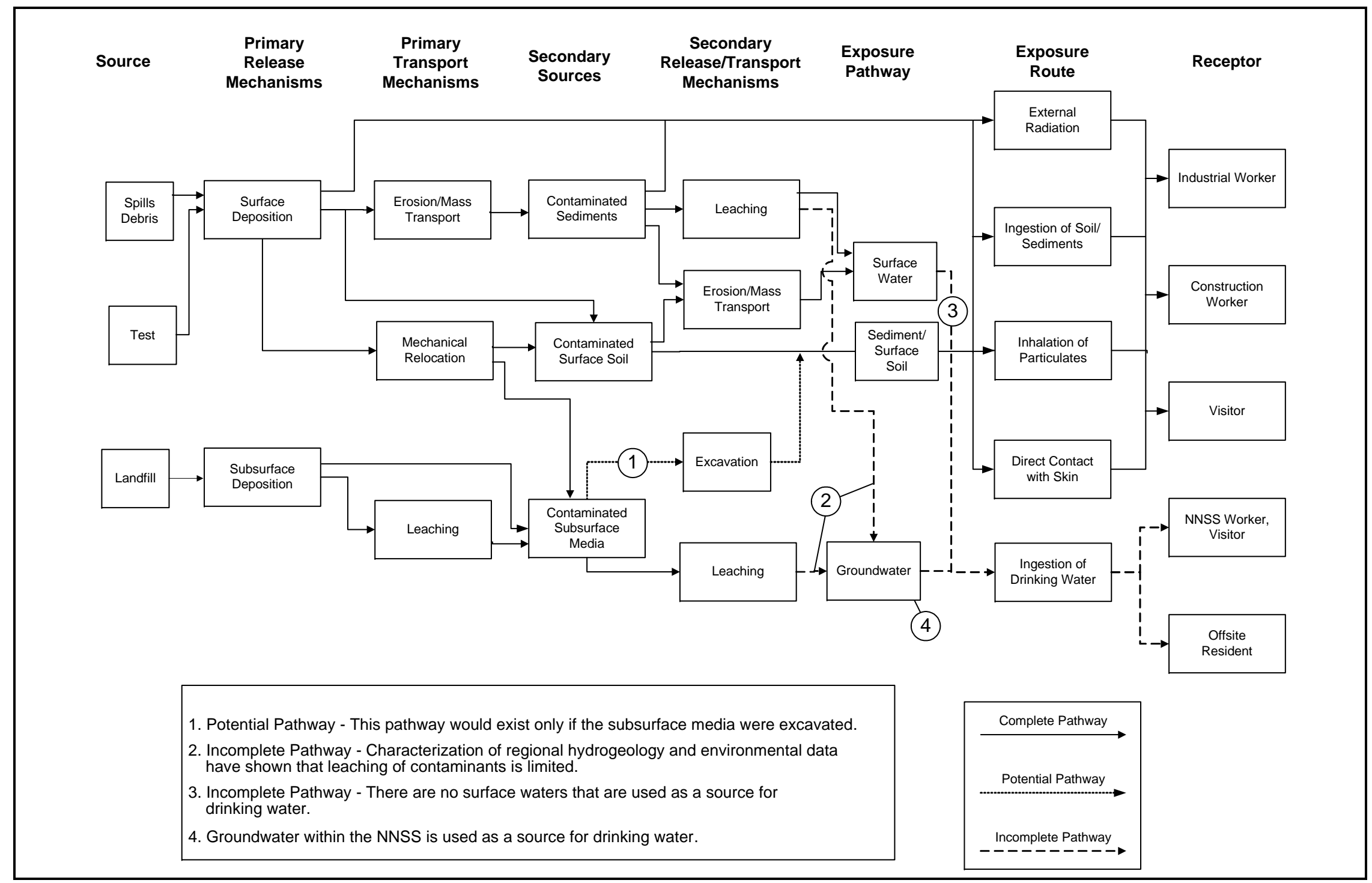

Figure 3-1

CSM Diagram 


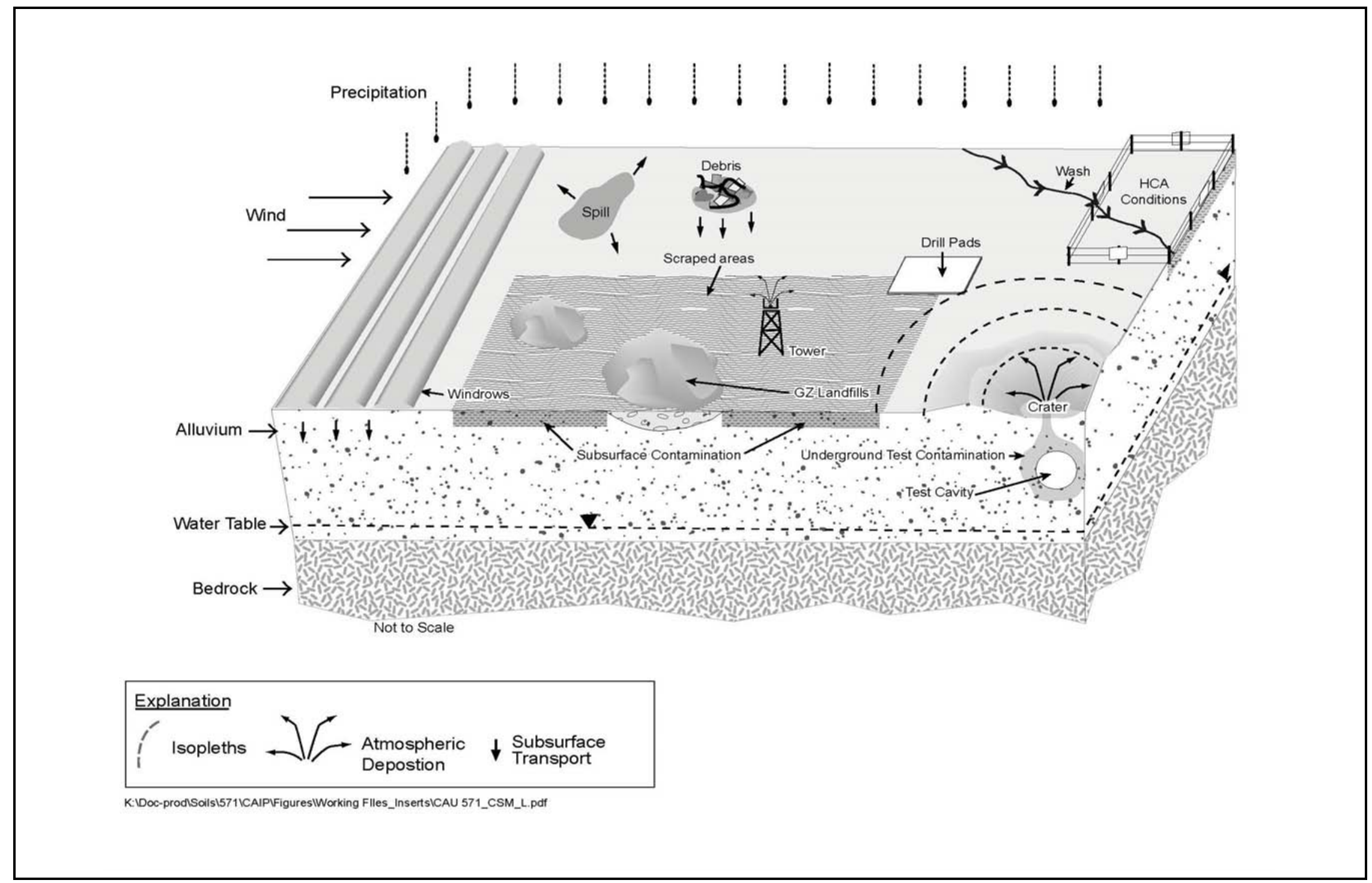

Figure 3-2

CAU 571 CSM 
CAU 571 is located in the land-use zone described as "Nuclear Test Zone" within the NNSS. This area is reserved for dynamic experiments, hydrodynamic tests, and underground nuclear weapons and weapons-effects tests. This zone includes compatible defense and nondefense research, development, and testing activities (DOE/NV, 1998).

Exposure scenarios for the CAU 571 sites have been categorized into the following three types based on current and projected future land uses:

- Industrial Area. This scenario addresses exposure to industrial workers exposed daily to contaminants in soil during an average workday. This scenario assumes that this is the regular assigned work area for the worker who will be on the site for an entire career (250 days per year, 8 hours per day, for 25 years). The total effective dose (TED) calculated using this exposure scenario is the TED an industrial worker receives during 2,000 hours of annual exposure to site contaminants and is expressed in terms of millirem per Industrial Area year (mrem/IA-yr).

- Remote Work Area. This exposure scenario assumes noncontinuous work activities at a site. This scenario addresses exposure to industrial workers exposed to contaminants in soil during a portion of an average workday. This scenario assumes that this is an area where the worker regularly visits but is not an assigned work area where the worker spends an entire workday. A site worker under this scenario is assumed to be on the site for an equivalent of 336 hours (or 42 days) per year for an entire career (25 years). The TED calculated using this exposure scenario is the TED a remote area worker receives during 336 hours of annual exposure to site radioactivity and is expressed in terms of millirem per Remote Work Area year (mrem/RW-yr).

- Occasional Use Area. This exposure scenario assumes occasional work activities at a site. This scenario addresses exposure to industrial workers who are not assigned to the area as a regular worksite but may occasionally use the site. This scenario assumes that this is an area where the worker does not regularly visit but may occasionally use for short-term activities. A site worker under this scenario is assumed to be on the site for an equivalent of 80 hours (or 10 days) per year for 5 years. The TED calculated using this exposure scenario is the TED an occasional use area worker receives during 80 hours of annual exposure to site radioactivity and is expressed in terms of millirem per Occasional Use Area year (mrem/OU-yr).

The CAU 571 land-use zone and exposure scenario are based on current and future land use at the NNSS. CAU 571 is a remote location without any site improvements and where no regular work is performed. There is still the possibility, however, that site workers could occupy these locations on an occasional and temporary basis such as a military exercise. Therefore, this site is classified as an Occasional Use Area. 


\subsubsection{Contaminant Sources}

Contaminant sources for CAU 571 CASs are the releases identified in Section 2.4 of radiological contamination to the atmosphere and soil as a result of two weapons-related tests (Post and Mazama) and two safety experiments (Vesta and Juno). Additional sources of potential contamination are the hot road oil that was sprayed on the Vesta and Juno landfills and windrows to fix contamination, hazardous debris that is PSM, and a pile of presumed asphalt material.

\subsubsection{Release Mechanisms}

As discussed in Section 2.4, the release mechanisms for CAU 571 are the four tests (two weapons-related tests and two safety experiments) that were conducted in close proximity and dispersed radionuclides. These tests released radionuclides onto the surface soil that was subsequently disturbed due to scraping and removing contamination in designated areas, burying contamination into landfills, creating windrows, reworking soil to support underground testing activities, and through the formation of drainages (Section 2.2). Other release mechanisms include placing debris and/or spills onto surface soils as a result of the testing activities.

\subsubsection{Migration Pathways}

Surface migration pathways for CAU 571 include the lateral migration of potential contaminants across surface soils into ephemeral drainages transecting the site since the original deposition. The washes entering and leaving these areas are generally dry but are subject to infrequent stormwater flows. These stormwater flow events provide an intermittent mechanism for both vertical (infiltration) and lateral transport of contaminants. Contaminated sediments entrained by these stormwater events would be carried by the streamflow to locations where the flowing water loses energy and the sediments drop out. These locations are readily identified as sedimentation areas. The area near CAU 571 drains into a wash located to the west of the site (investigated in CAU 570, Area 9 Yucca Flat Atmospheric Test Sites) that flows toward Yucca Flat Dry Lake. There is an ephemeral wash forming along the south side of the 9-01 Road and adjacent to a man-made structure (mud pit) that could result in the migration of potential contaminants from CAU 571. Other migration pathways for contamination from the site include wind-borne material and material displaced from roads in the vicinity (e.g., moved during road maintenance). 
Potential migration pathways include the lateral migration of contaminants across soil surface and accumulation in drainages and craters, and vertical migration of potential contaminants into the subsurface soils. Contaminants may also be moved through mechanical disturbance due to maintenance or construction activities at the site. Specifically, this can include activities such as removing surface contamination through scraping or grading, reworking soil during the construction of drill pads and roads, and other similar activities.

Migration is influenced by physical and chemical characteristics of the contaminants and media. Contaminant characteristics include, but are not limited to, solubility, density, and adsorption potential. Media characteristics include permeability, porosity, water-holding capacity, sorting, chemical composition, and organic content. In general, contaminants with low solubility, high affinity for media, and high density can be expected to be found relatively close to release points. Contaminants with high solubility, low affinity for media, and low density can be expected to be found farther from release points. These factors affect the migration pathways and potential exposure points for the contaminants in the various media under consideration.

Infiltration and percolation of precipitation serve as a driving force for downward migration of contaminants. However, due to high PET (annual PET at the Area 3 RWMS has been estimated at 61.8 in. and limited precipitation for this region [6.3 in. per year]), percolation of infiltrated precipitation at the NNSS does not provide a significant mechanism for vertical migration of contaminants to groundwater (Soule', 2006; DOE/NV, 1992).

Subsurface migration pathways at CAU 571 are expected to be predominately vertical, although spills or leaks at the ground surface may also have limited lateral migration before infiltration. The depth of infiltration (shape of the subsurface contaminant plume) will be dependent upon the type, volume, and duration of the discharge as well as the presence of relatively impermeable layers that could modify vertical or lateral transport pathways, both on the ground surface (e.g., concrete) and in the subsurface (e.g., caliche layers).

Underground test craters have associated chimneys of disturbed geologic material that may provide a preferential pathway. Collection of stormwater into these craters also provides additional localized infiltration that will enhance contaminant migration rates. 


\subsubsection{Exposure Points}

Exposure points for the CSM are expected to be areas of surface contamination where visitors and site workers may come in contact with contaminated surface soil. Subsurface exposure points may exist if construction workers come in contact with contaminated media during excavation activities.

\subsubsection{Exposure Routes}

Exposure routes to site workers include ingestion and inhalation from disturbance of, or direct contact with, contaminated media. Site workers may also be exposed to direct ionizing radiation by performing activities in proximity to radioactive materials.

\subsubsection{Additional Information}

Information concerning topography, geology, climatic conditions, hydrogeology, floodplains, and infrastructure at the CAU 571 sites is presented in Section 2.1 as it pertains to the investigation. This information has been addressed in the CSM and will be considered during the evaluation of CAAs, as applicable. Climatic and site conditions (e.g., surface and subsurface soil descriptions) as well as specific structure descriptions will be recorded during the CAI. Areas of erosion and deposition within the washes will be qualitatively evaluated to provide additional information on potential offsite migration of contamination. Movement of ephemeral drainage channels may be identified based on a comparison of historical photographs and visual observations where erosion and deposition have occurred within the washes.

\subsection{Contaminants of Potential Concern}

The COPCs for CAU 571 are defined as the contaminants reasonably expected at the site that could contribute to a dose or risk exceeding FALs. Based on the nature of the releases identified in Section 2.4 and previous investigation results presented in Section 2.5, the contaminants that could reasonably be suspected to be present at CAU 571 are uranium (U)-234, -235/236, -238; Pu-238, -239/240, -241; cesium (Cs)-137; and Am-241 (see Table A.2-2). Additionally, lead is a COPC at Study Group 5. These COPCs were identified during the planning process through the review of site history, process knowledge, personal interviews, past investigation efforts (where available), and inferred activities associated with the CASs and other releases (including those that may be 
discovered during the investigation). Other specific COPCs (and subsequently the analyses requested) will be determined for discovered potential releases based on the nature of the potential release (e.g., stains).

Although not suspected to be present, analysis for other COPCs will be performed to eliminate the possibility of their presence due to an incomplete history of site testing operations as discussed in Section A.2.2.2. These COPCs will be reported by the analytical methods identified in Table A.2-3 for environmental samples taken at each of the sites. The analytes reported for each analytical method are listed in Table A.2-4.

\subsection{Preliminary Action Levels}

The PALs presented in this section are to be used for site screening purposes. They are not necessarily intended to be used as cleanup action levels or FALs. However, they are useful in screening out contaminants that are not present in sufficient concentrations to warrant further evaluation, thereby streamlining the consideration of remedial alternatives. The RBCA process used to establish FALs is described in the Soils RBCA document (NNSA/NSO, 2012c). This process conforms with Nevada Administrative Code (NAC) 445A.227, which lists the requirements for sites with soil contamination (NAC, 2012a). For the evaluation of corrective actions, NAC 445A.22705 (NAC, 2012b) requires the use of ASTM International (ASTM) Method E1739 (ASTM, 1995) to "conduct an evaluation of the site, based on the risk it poses to public health and the environment, to determine the necessary remediation standards or to establish that corrective action is not necessary." For the evaluation of corrective actions, the FALs are established as the necessary remedial standard.

This RBCA process, summarized in Figure 3-3, defines three tiers (or levels) of evaluation involving increasingly sophisticated analyses:

- Tier 1 evaluation. Sample results from source areas (highest concentrations) are compared to action levels based on generic (non-site-specific) conditions (i.e., the PALs established in the CAIP). The FALs may then be established as the Tier 1 action levels, or the FALs may be calculated using a Tier 2 evaluation.

- Tier 2 evaluation. Conducted by calculating Tier 2 action levels using site-specific information as inputs to the same or similar methodology used to calculate Tier 1 action levels. The Tier 2 action levels are then compared to individual sample results from 


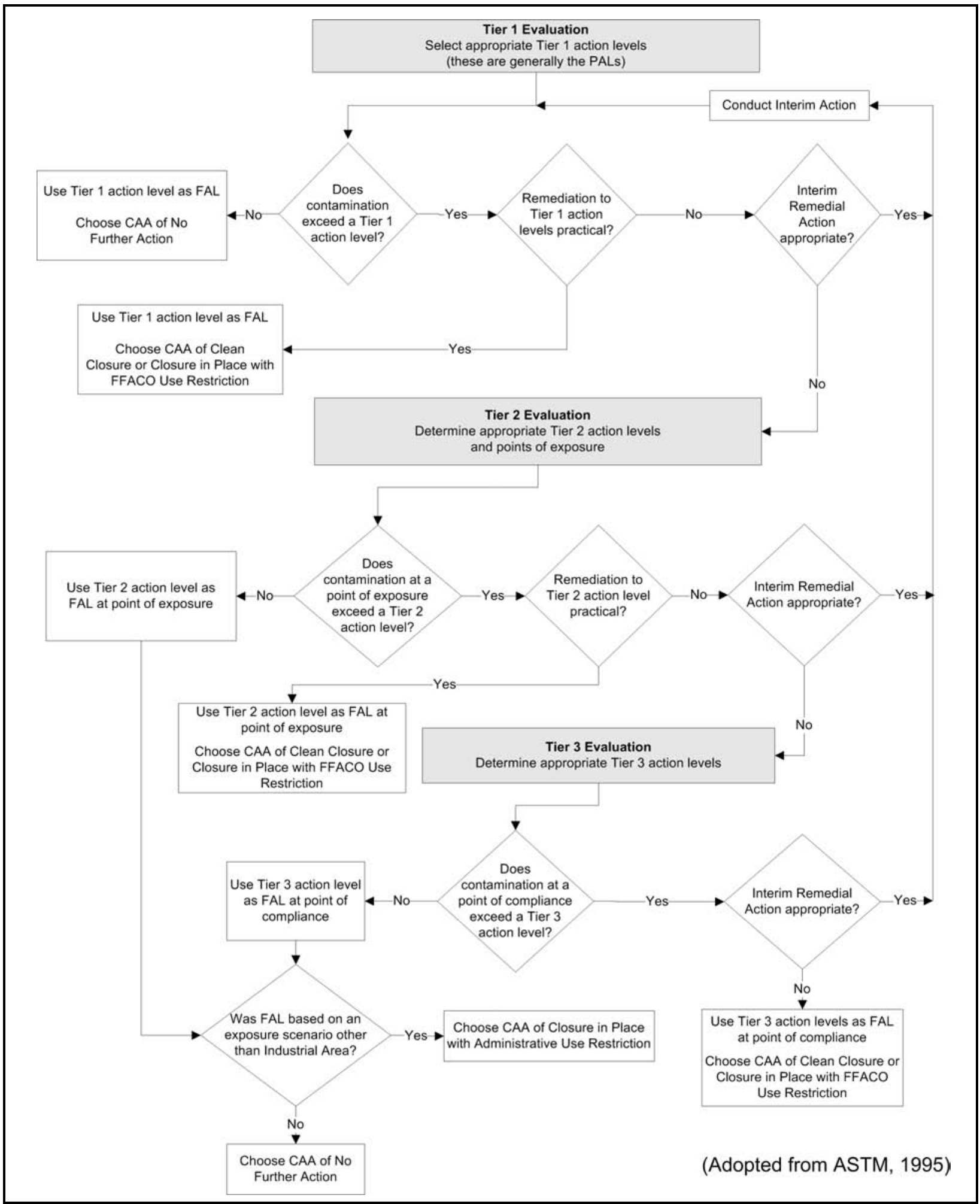

Figure 3-3

RBCA Decision Process 
reasonable points of exposure (as opposed to the source areas as is done in Tier 1) on a point-by-point basis. Results from total petroleum hydrocarbons (TPH) analyses will not be used for risk-based decisions under Tier 2 or Tier 3. Rather, the individual chemical constituents of diesel reported from volatile organic compound (VOC) and semivolatile organic compound (SVOC) analyses will be compared to the action levels.

- Tier 3 evaluation. Conducted by calculating Tier 3 action levels on the basis of more sophisticated risk analyses using methodologies described in Method E1739 that consider site-, pathway-, and receptor-specific parameters.

This RBCA process includes a provision for conducting an interim remedial action if necessary and appropriate. The decision to conduct an interim action may be made at any time during the investigation and at any level (tier) of analysis. Concurrence of the decision makers listed in Section A.2.1 will be obtained before any interim action is implemented. Evaluation of DQO decisions will be based on conditions at the site after any interim actions are completed. Any interim actions conducted will be reported in the investigation report.

If, after implementation of corrective actions, contamination remains in place that is less than the site-specific exposure scenario based FAL but exceeds 25 millirem per year (mrem/yr) based on the Industrial Area exposure scenario, an administrative use restriction will be implemented to prevent future industrial use of the area. For this reason, contamination at all sites will be evaluated against industrial exposure scenario based PALs and site-specific exposure scenario based FALs. The FALs (along with the basis for their selection) will be proposed in the investigation report, where they will be compared to laboratory results in the evaluation of potential corrective actions.

\subsubsection{Chemical PALs}

Except as noted herein, the chemical PALs are defined as the U.S. Environmental Protection Agency (EPA) Region 9 Regional Screening Levels for chemical contaminants in industrial soils (EPA, 2013a). Background concentrations for Resource Conservation and Recovery Act (RCRA) metals will be used instead of screening levels when natural background concentrations exceed the screening level, as is often the case with arsenic on the NNSS. Background is considered the mean plus two standard deviations of the mean for sediment samples collected by the Nevada Bureau of Mines and Geology throughout the Nevada Test and Training Range (formerly the Nellis Air Force Range) (NBMG, 1998; Moore, 1999). For detected chemical COPCs without established screening 
levels, the protocol used by EPA Region 9 in establishing screening levels (or similar) will be used to establish PALs. If used, this process will be documented in the investigation report.

\subsubsection{Radionuclide PALs}

The PAL for radioactive contaminants is a TED of $25 \mathrm{mrem} / \mathrm{yr}$, based upon the Industrial Area exposure scenario. The Industrial Area exposure scenario is described in the Soils RBCA document (NNSA/NSO, 2012c). The TED is calculated as the sum of external dose and internal dose. External dose is determined using TLD measurements. Internal dose is determined by comparing analytical results from soil samples to residual radioactive material guidelines (RRMGs) that were established using the RESRAD computer code (Yu et al., 2001). RRMGs are radionuclide-specific values for radioactivity in surface soils. The RRMG is the value, in picocuries per gram of surface soil, for a particular radionuclide that would result in an internal dose of $25 \mathrm{mrem} / \mathrm{yr}$ to a receptor (under the appropriate exposure scenario) independent of any other radionuclide (assuming that no other radionuclides contribute dose). The RRMGs are presented in the Soils RBCA document.

In the RESRAD calculation, several input parameters are not specified so that site-specific information can be used. The default and site-specific input parameters used in the RESRAD calculation of RRMGs for each exposure scenario are listed in the Soils RBCA document (NNSA/NSO, 2012c).

\subsection{DQO Process Discussion}

This section contains a summary of the DQO process that is presented in Appendix A. The DQO process is a strategic planning approach based on the scientific method that is designed to ensure that the data collected will provide sufficient and reliable information to identify, evaluate, and technically defend the recommendation of viable corrective actions (e.g., no further action, clean closure, or closure in place).

As presented in Section 4.1, it is assumed that TED within the default contamination boundaries (i.e., HCAs at the Juno landfill and central windrows, small HCA north of Vesta, the Vesta landfill, the CA at Mazama, and the URMA pile) exceed the FAL (see Section 4.1). For these areas, the DQO 
decisions are resolved and corrective action is required. DQO decisions will be resolved for the areas outside the default contamination boundaries.

As presented in Section 1.1.2, the DQOs address five types of potential contaminant release types (i.e., study groups). For each study group, releases will be investigated using different sampling techniques. Therefore, discussions related to each study group are presented separately.

The DQO strategy for CAU 571 was developed at a meeting on March 6, 2013. DQOs were developed to identify data needs, clearly define the intended use of the environmental data, and to design a data collection program that will satisfy these purposes. During the DQO discussions for this CAU, the informational inputs or data needs to resolve problem statements and decision statements were documented.

The problem statement for CAU 571 is as follows: "Existing information on the nature and extent of potential contamination is insufficient to evaluate and recommend CAAs for the CASs in CAU 571.” To address this problem statement, resolution of the following decision statements is required:

- Decision I. "Is any COC associated with the CAU 571 release present in environmental media?” If a COC is detected, then Decision II must be resolved.

- Decision II. “Is sufficient information available to evaluate potential CAAs?” Sufficient information is defined to include the following:

- The lateral and vertical extent of COC contamination

- The information needed to determine potential remediation waste types

- The information needed to evaluate the feasibility of remediation alternatives

The presence of a COC would require a corrective action. A corrective action may also be necessary if there is a potential for wastes (i.e., PSM) that are present at a site to introduce COCs into site environmental media. Several conservative assumptions were made to evaluate the potential for wastes to introduce a COC to the surrounding environmental media. These assumptions are detailed in the Soils RBCA document (NNSA/NSO, 2012c).

It is unknown whether COCs are present outside the default contamination boundaries. Therefore, Decision I sampling will be conducted for all of the study groups. If COCs are identified, Decision II must be resolved for all of the study groups. If necessary, samples will be submitted to define the 
extent of unbounded COCs. In addition, samples will be submitted for analyses, as needed, to support waste management or health and safety decisions.

For the laboratory data, the data quality indicators (DQIs) of precision, accuracy, representativeness, completeness, comparability, and sensitivity needed to satisfy DQO requirements are discussed in Section 6.2. Laboratory data will be assessed in the investigation report to confirm or refute the CSM and determine whether the DQO data needs were met. 


\subsection{Field Investigation}

This section contains a description of the activities to be conducted to gather and document information from the CAU 571 field investigation.

\subsection{Technical Approach}

The information necessary to satisfy the DQO data needs will be generated for CAU 571 by collecting and analyzing samples generated during a field investigation. However, the investigation will not include the areas within the CAU that contain removable radioactivity that exceeds the criteria for establishing an HCA (defined in the Soils RBCA document [NNSA/NSO, 2012c]), as contamination exceeding FALs is assumed to be present within these areas. For the HCAs at Juno, Mazama, north of Vesta, and the central windrows, this assumption is based on the potential for a receptor in these areas to inhale, ingest, and transport this removable contamination. The Vesta landfill and the URMA pile are assumed to contain contamination exceeding FALs based on available process knowledge that they were used to dispose of contaminated material (Sections 2.2.2 and 2.5.4) and the impracticality of characterizing a heterogeneous landfill. Default contamination boundaries have been established at these locations, and corrective actions are required. For the area outside the default contamination boundaries, information will be generated during a site investigation to resolve DQO decisions. Figure 4-1 shows the default contamination boundaries associated with CAU 571.

The presence and nature of contamination decision (Decision I) will be a judgmental decision determined using sample results from biased locations under a judgmental sampling design. For sample plot locations, each Decision I sample plot will generate a TED value for the judgmental decision that represents the population of doses within the 100-square-meter area of the sample plot. This representative TED value will be determined using probabilistic sampling design to generate a 95 percent UCL of the average TED within the plot area. For grab sample locations, DQO decisions will be based on a direct comparison of sample results to the FAL.

The extent of radiological COC contamination decision (Decision II) will be a probabilistic decision determined by correlating TED and radiological survey values as described in the Soils RBCA document (NNSA/NSO, 2012c). This method will only be used if the correlation between TED and 


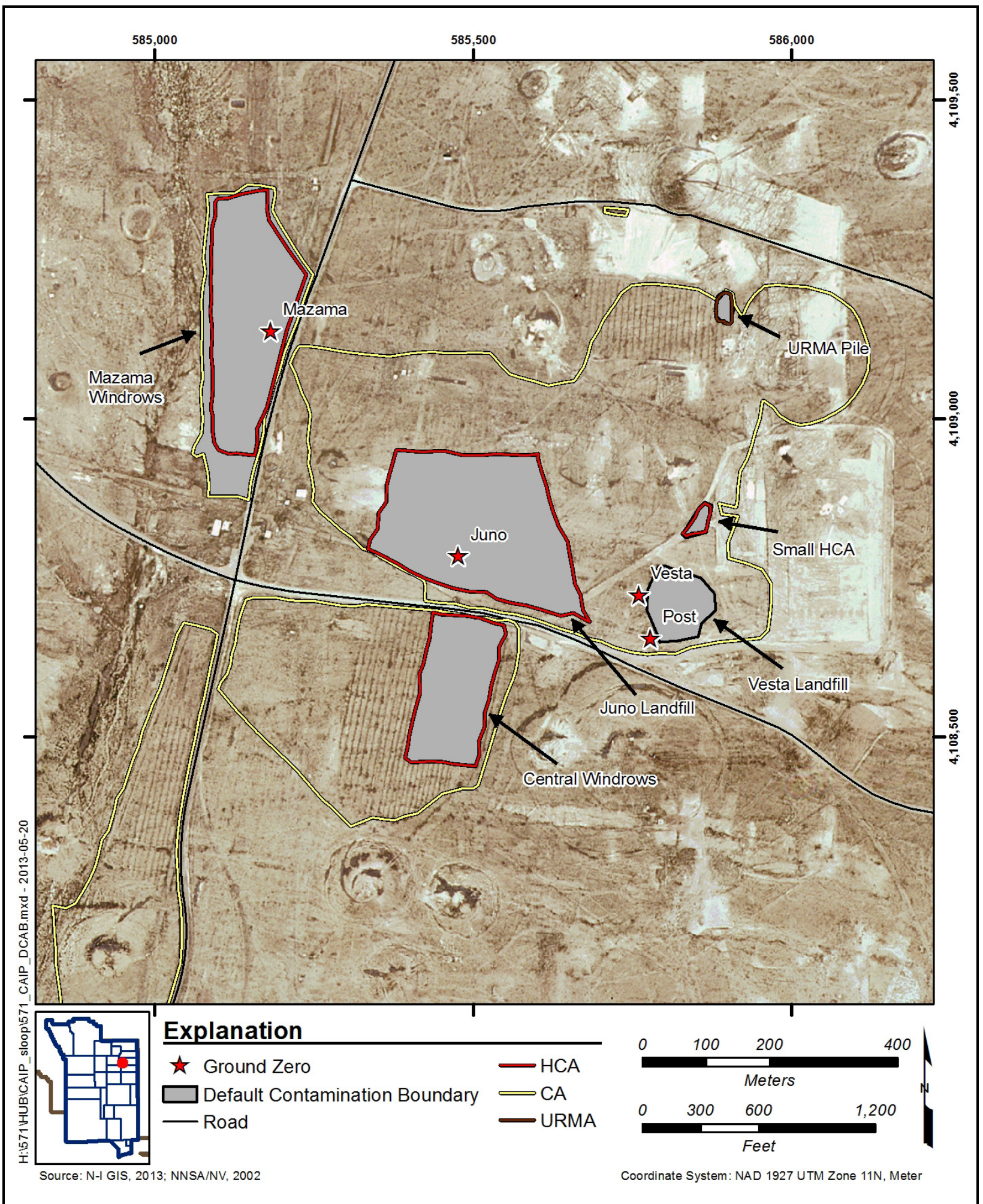

Figure 4-1 CAU 571 Default Contamination Boundaries 
the survey values has a coefficient of determination $\left(\mathrm{r}^{2}\right)$ greater than 0.8 . The statistical relationship among the correlated values can then be used to estimate the radiation survey value that represents a 95 percent lower confidence limit (LCL) of the correlation. This will conservatively estimate the radiation survey value that represents a TED of $25 \mathrm{mrem} / \mathrm{yr}$ (under the appropriate exposure scenario). This correlation between the radiation survey and the TLD will be completed for each radiation survey (e.g., terrestrial radiological survey, aerial) to identify the radiation survey that has the best correlation to TED values.

The TED will be calculated using the methodologies described in the Soils RBCA document (NNSA/NSO, 2012c).

Modifications to the investigative strategy may be required should unexpected field conditions be encountered at any site. Significant modifications must be justified and documented before implementation. If an unexpected condition indicates that conditions are significantly different from the CSM, the activity will be rescoped and the identified decision makers will be notified.

\subsection{Field Activities}

Field activities at CAU 571 include site preparation, sample location selection, sample collection, and demobilization.

\subsubsection{Site Preparation Activities}

Site preparation activities to be conducted before the start of environmental sampling may include relocating or removing surface debris, equipment, and structures; constructing hazardous waste accumulation areas (HWAAs) and site exclusion zones; providing sanitary facilities; constructing decontamination facilities; and moving staged equipment.

Before mobilization for collecting investigation samples, the following preparatory activities will also be conducted:

- Perform terrestrial radiological surveys to identify bias used in selecting sample locations. 
- Install activity-specific environmental monitoring TLDs (see Section 4.2.3 for additional information).

- Perform visual surveys at all sites within CAU 571 to identify any staining, discoloration, disturbance of native soils, or any other indication of potential contamination.

\subsubsection{Sample Location Selection}

Rationale for selecting areas for sampling is discussed in the following subsections. For all investigations, if a spatial boundary is reached, the CSM is shown to be inadequate, or the Site Supervisor determines that extent sampling needs to be reevaluated, then work will be temporarily suspended, NDEP will be notified, and the investigation strategy will be reevaluated.

The sampling strategy and the estimated locations of biased samples are presented in Appendix A. The Task Manager or Site Supervisor may modify the number, location, and spacing of step-outs as warranted by site conditions to achieve DQO criteria stipulated in Appendix A. Where sampling locations are modified, the justification for these modifications will be documented in the investigation report.

As presented in Section 4.1, it is assumed that corrective action is required within the default contamination boundaries. Therefore, sampling of these areas is not necessary. Sample location selection specific to each Study Group is discussed in Sections 4.2.2.1 through 4.2.2.5.

\subsubsection{Study Group 1, Atmospheric Release}

The soil impacted by the atmospheric releases was disturbed in the areas closest to the GZs. Therefore, the remaining relatively undisturbed atmospheric release area available to sample where contamination would be located in the top $5 \mathrm{~cm}$ is limited and located beyond the area of disturbed soil (i.e., Study Group 2). One Decision I sample plot will be selected at the highest radiological survey value in each of three different near the boundary of the disturbed soil (i.e., Study Group 2) but within the Study Group 1 boundary. The Study Group 1 boundary and sample locations are shown in Figure A.8-1.

Although additional radiological surveys may be required, preliminary investigation terrestrial radiological survey values are very near background so no Decision II sample locations have been 
selected. If the 95 percent UCL of the TED at the Decision I sample plot exceeds the FAL, NDEP will be notified and the investigation strategy will be reevaluated.

\subsubsection{Study Group 2, Subsurface Contamination}

Most of the contamination present as a result of the atmospheric releases was disturbed and is captured within the Study Group 2 boundary. Because soil has been disturbed, there is a potential for radionuclides associated with atmospheric releases to be present at depths greater than $5 \mathrm{~cm}$.

In order to characterize the surface soil, two Decision I sample plots will be selected in the areas of highest radiological survey values identified within the Study Group 2 boundary. Additionally, 14 Decision I sample plots will be selected adjacent to, but outside, the default contamination boundaries at the Juno and Vesta GZs. There will be eight sample plots surrounding the HCA fence at Juno (two on each side), and six sample plots in a circle surrounding the Vesta landfill. In order to characterize subsurface soil, a subsurface sample may be collected from the center of each sample plot based on the criteria defined in Section A.8.2.2. The Study Group 2 boundary and sample locations are shown in Figure A.8-3.

Although additional radiological surveys may be required, preliminary investigation terrestrial radiological survey values indicate that the highest surface radiological values are located west of and adjacent to the Vesta landfill.

No Decision II sample locations will be required for Study Group 2. If the 95 percent UCL of the TED at any Decision I sample plot exceeds the FAL, Study Group 2 will require corrective action.

\subsubsection{Study Group 3, Windrows}

The radioactive contamination on surface soils that was left in situ and scraped into windrows exhibits contamination consistent with the original atmospheric release plume directions from Juno (southward) and Vesta (northward). The residual spatial distribution of radionuclides visible on both the 2012 aerial radiological surveys and recent terrestrial radiological surveys confirm that contamination generally decreases with distance from the GZs. 
Although the windrows were created as a result of contamination scraped in place, there is the potential that some transfer of contamination took place during the decontamination of the access road and when the windrows were disturbed from their original configuration. Therefore, to adequately investigate the windrows, the windrows have been categorized into five zones based on proximity to the Juno and Vesta GZs, location along the access road, and radiological postings (Table 4-1). Two Decision I sample locations will be selected in each of the zones from areas with the highest radiological values. If the 95 percent UCL of the TED at an individual Decision I sample location exceeds the FAL, that zone will require corrective action and additional sample locations will be selected until the criteria for defining the extent of contamination listed in Section A.4.1 is met. The Study Group 3 zone boundaries and sample locations are shown in Figure A.8-4.

Table 4-1

Windrow Zones

\begin{tabular}{|c|l||}
\hline Zone & \multicolumn{1}{|c|}{ Zone Description } \\
\hline \hline 1 & $\begin{array}{l}\text { Zone } 1 \text { consists of original windrows located in the northern portion of the CAU 571 area and } \\
\text { primarily comprises potential contamination from the Vesta plume. This zone is located relatively } \\
\text { close in proximity to the Vesta GZ. This zone is located in a CA. }\end{array}$ \\
\hline 2 & $\begin{array}{l}\text { Zone } 2 \text { consists of original and disturbed windrows located in the central portion of the CAU 571 } \\
\text { area and primarily comprises potential contamination from the Juno plume. This zone is located } \\
\text { relatively close in proximity to the Juno GZ. This zone is partially within an HCA and a CA while } \\
\text { some of the area is not radiologically posted. }\end{array}$ \\
\hline 3 & $\begin{array}{l}\text { Zone } 3 \text { consists of original windrows located in the southwestern portion of the CAU 571 area. } \\
\text { These windrows may contain contamination from the Juno plume but may also include } \\
\text { contamination from the decontamination of the access road. This zone is posted as a CA. }\end{array}$ \\
\hline 4 & $\begin{array}{l}\text { Zone } 4 \text { consists of original windrows located in the southern portion of the CAU 571 area. This } \\
\text { area is relatively small but was separated out as a zone because it is a CA and is still in original } \\
\text { windrow condition beyond the disturbed windrows. The potential contamination in this zone is } \\
\text { likely from the Juno plume as well as from the decontamination of the access road. }\end{array}$ \\
\hline 5 & $\begin{array}{l}\text { Zone } 5 \text { consists of the remaining windrows to the south of the CAU 571 area that are not within a } \\
\text { CA. The potential contamination is likely from the decontamination of the access road. }\end{array}$ \\
\hline
\end{tabular}

\subsubsection{Study Group 4, Drainage}

The drainage that travels along the south side of 9-01 Road near man-made features will be visually and radiologically surveyed. The visual survey will be conducted to identify sediment accumulation areas. A Decision I sample location will be established at the center of the nearest two downgradient sediment accumulation areas that could be impacted by radionuclides associated with the CAU 571 releases. A radiological survey will be conducted to identify elevated readings where additional judgmental sample locations may be selected. The location of the drainage is shown in Figure A.8-5. 
Decision II will be resolved for drainages by the assumption that the entire volume of sediment in each sediment accumulation area where a COC is identified contains the COC. Additional sedimentation areas will be sampled until at least two consecutive sedimentation areas are found that do not contain a COC or until the drainage enters the main drainage that was investigated in CAU 570.

\subsubsection{Study Group 5, Other}

Decision I evaluation for this study group will be based on the feature being investigated to determine the presence of a COC. For PSM, a sample will be collected from below the debris or spill. At the asphalt pile, a sample will be collected from below the pile and also at the downgradient toe of the pile. A sample plot will be placed within the northern CA at the location of the highest radiological values as identified on a terrestrial radiological survey.

Where COCs have been confirmed based on validated laboratory analytical results, Decision II sampling will be conducted to define the extent of contamination. Depending upon the nature of the identified release, the extent of radiological COC contamination will be defined using one of the methods described in Section A.4.1. The locations of debris, asphalt pile, and northern CA are shown in Figure A.8-6.

If a COC is present at a PSM location, the COC may be removed under an interim action. If an interim action removal is conducted, verification samples will be collected to demonstrate that all soils exceeding the FAL were removed. Otherwise, extent (Decision II) sampling will be completed.

\subsubsection{Sample Collection}

The CAU 571 sampling program will consist of the following activities:

- Collect soil samples from locations as described in Section 4.2.2.

- Collect required QC samples.

- Collect waste management samples as necessary.

- Collect external dose measurements by hanging TLDs at the sample plots or sample locations. 
- Collect soil samples from locations outside the influence of releases, if necessary.

- Record Global Positioning System (GPS) coordinates for each environmental sample location.

To determine internal dose at sample plot locations within Study Groups 1, 2, and 5, a probabilistic sampling approach will be implemented for collecting composite samples within the sample plots. Each composite sample will consist of soil collected from the surface to a depth of $5 \mathrm{~cm}$ at nine randomly located subsample locations within the plot. For each composite sample, the first location will be selected randomly; the remaining eight subsample locations will be established on a systematic triangular grid (see Section A.8.0). External dose will be sampled from a TLD installed at the approximate center of the sample plot at a height of $1 \mathrm{~m}$ and be left in place for approximately 2,000 hours (equivalent to an annual industrial worker exposure).

To determine internal dose for surface and/or subsurface grab samples in Study Groups 2 and 4, a judgmental sampling approach will be implemented at the sample locations described in Sections 4.2.2.2 and 4.2.2.4. For Study Group 2, in order to evaluate the subsurface soil for the presence of contamination, one location at the center of each sample plot will be screened in 5-cm depth intervals until native material is encountered using the appropriate tool or equipment. At each subsurface screening location, a sample may be collected based on an increase in the screening values. For Study Group 4, each sediment accumulation area identified for sampling will be screened in 5- or 10-cm depth intervals until native material is encountered using the appropriate tool or equipment. Each interval will be screened with an alpha/beta detection meter. If the field-screening result (FSR) is greater than the daily field-screening level (FSL) and 20 percent higher than the surface sample, both the surface sample and the depth interval with the highest FSR will be submitted for analysis.

Because soil within the windrows in Study Group 3 is slightly mounded above the ground surface, the entire soil profile from the surface to the base or native soil interface will be composited and submitted as one grab sample at each location selected as described in Section 4.2.2.3. No subsurface soil screening will be required as the sample will include all soil contained within the vertical profile of the windrow. 
For Study Group 5, a judgmental sampling approach will be implemented for collecting samples at the selected locations as described in Section 4.2.2.5 (i.e., PSM or staining indicating potential spill). Surface samples will be collected at an interval of 0 to $5 \mathrm{~cm}$ bgs. If biasing factors are present in soils below locations where Decision I sample were collected, subsurface soil samples will also be collected, as appropriate, using the appropriate tool or equipment. If the COPCs are radionuclides only, subsurface screening as described above for Study Groups 2 and 4 will apply.

\subsubsection{Sample Management}

The laboratory requirements (i.e., precision, accuracy) to be used when analyzing the COPCs are presented in the Soils QAP (NNSA/NSO, 2012b). The analytical program is presented in Table A.2-3. All sampling activities and QC requirements for field and laboratory environmental sampling will be conducted in compliance with the Soils QAP.

\subsection{Site Restoration}

Upon completion of CAI and waste management activities, the following actions will be implemented before closure of the site Real Estate/Operations Permit (REOP):

- All equipment, wastes, debris, and materials associated with the CAI will be removed from the site.

- All CAI-related signage and fencing (unless part of a corrective action) will be removed from the site.

- Site will be inspected to ensure restoration activities have been completed. 
Waste generated during the CAU 571 field investigation will be managed in accordance with all applicable DOE orders, federal and state regulations, and agreements and permits between DOE and NDEP. Wastes will be characterized based on these regulations using process knowledge, FSRs, and analytical results from investigation and waste samples. Waste types that may be generated during the CAI include industrial, hazardous, hydrocarbon, Toxic Substances Control Act (TSCA) regulated (e.g., polychlorinated biphenyls [PCBs], asbestos), low-level radioactive, or mixed wastes.

Disposable sampling equipment, PPE, and rinsate are considered potentially contaminated waste only by virtue of contact with potentially contaminated media (e.g., soil) or potentially contaminated debris (e.g., lead). These wastes may be characterized based on associated environmental sample results, waste characterization results, FSRs, or process knowledge.

Chemicals were not known to be used or present at this CAU in a manner that would generate listed hazardous waste; therefore, wastes will be characterized based on their chemical characteristics. The waste will be managed and disposed of accordingly.

Conservative estimates of total waste contaminant concentrations may be made based on the mass of the waste, the amount of contaminated media contained in the waste, and the maximum concentration of contamination found in the media.

The following subsections discuss how the field investigation will be conducted to minimize the generation of waste, what waste streams are expected to be generated, and how IDW will be managed.

\subsection{Waste Minimization}

The CAI will be conducted in a manner that will minimize the generation of wastes using process knowledge, segregation, visual examination, and/or field screening (e.g., radiological survey and swipe results) to avoid cross-contaminating uncontaminated media or uncontaminated IDW that would otherwise be characterized and disposed of as industrial waste. As appropriate, media and debris will be returned to their original location. To limit unnecessary generation of hazardous or 
mixed waste, hazardous materials will not be used during the CAI unless required and approved by Environmental Compliance and Health and Safety. Other waste minimization practices will include, as appropriate, avoiding contact with contaminated materials, performing dry decontamination or wet decontamination over source locations, and carefully segregating waste streams.

\subsection{Potential Waste Streams}

The following is a list of common waste streams that may be generated during the field investigation and that may require management and disposal:

- Disposable sampling equipment and field screening waste

- PPE

- Environmental media (e.g., soil)

- $\quad$ Surface debris (e.g., lead bricks, batteries, scrap metal)

- Decontamination rinsate

\subsection{IDW Management}

The onsite management of IDW will be determined based on regulations associated with the particular waste type (e.g., industrial, low-level), or the combination of waste types. The following subsections describe how specific waste types will be managed.

\subsubsection{Industrial Waste}

Industrial solid waste, if generated, will be collected, managed, and disposed of in accordance with the solid waste regulations and the permits for operation of the NNSS Solid Waste Disposal Sites. The most commonly generated industrial solid waste includes disposable sampling equipment and PPE that will be collected in plastic bags, and managed in accordance with requirements.

\subsubsection{Hazardous Waste}

Suspected hazardous waste, if generated, will be containerized and managed in waste accumulation areas in accordance with 40 Code of Federal Regulations (CFR) Parts 260 to 280 (CFR, 2012a). 


\subsubsection{Hydrocarbon Waste}

Suspected hydrocarbon solid waste, if generated, will be managed on site in a drum or other appropriate container until fully characterized and in accordance with the State of Nevada regulations (NDEP, 2006).

\subsubsection{Polychlorinated Biphenyls}

The management of PCBs is governed by TSCA and its implementing regulations at 40 CFR 761 (CFR, 2012b), and agreements between EPA and NDEP. PCB contamination may be found as a sole contaminant or in combination with any of the types of waste discussed in this document. For example, PCBs may be a co-contaminant in soil that contains a RCRA “characteristic” waste (PCB/hazardous waste), or in soil that contains radioactive wastes (PCB/radioactive waste), or even in mixed waste (PCB/radioactive/hazardous waste). IDW will initially be evaluated using analytical results for media samples from the CAI. If any type of PCB waste is generated, it will be managed in accordance with 40 CFR 761 (CFR, 2012b) as well as State of Nevada requirements (NAC, 2012c), guidance, and agreements with NNSA/NFO.

\subsubsection{Low-Level Waste}

Low-level radioactive waste, if generated, will be managed in accordance with the contractor-specific waste certification program plan, DOE orders, and the requirements of the current version of the Nevada National Security Site Waste Acceptance Criteria (NNSA/NSO, 2012a). Potential radioactive waste containers will be staged and managed at a designated radioactive material area (RMA).

\subsubsection{Mixed Low-Level Waste}

Mixed waste, if generated, will be managed in accordance with the RCRA requirements (CFR, 2012b), agreements between NNSA/NFO and the State of Nevada, and DOE requirements for radioactive waste. Waste characterized as mixed will not be stored for a period of time that exceeds the RCRA requirements unless subject to agreements between NNSA/NFO and the State of Nevada. The mixed waste must be transported via an approved hazardous waste/radioactive waste transporter to the NNSS transuranic waste storage pad for storage pending treatment or disposal. 


\subsection{Quality Assurance/Quality Control}

The overall objective of the characterization activities described in this CAIP is to collect accurate and defensible data to support the selection and implementation of a closure alternative for CASs in CAU 571. All characterization activities, including those related to TLD measurements, will be conducted in accordance with the Soils QAP (NNSA/NSO, 2012b) and the Soils RBCA document (NNSA/NSO, 2012c), which defines rigorous data quality requirements. Sections 6.1 and 6.2 discuss the collection of required QC samples in the field and QA requirements for soil samples.

\subsection{QC Sampling Activities}

Field QC samples will be collected in accordance with established procedures. Field QC samples are collected and analyzed to aid in determining the validity of environmental sample results. The number of required QC samples depends on the types and number of environmental samples collected. As determined in the DQO process, the minimum frequency of collecting and analyzing QC samples for this investigation is as follows:

\section{- Radiological samples}

- Field duplicates for grab samples (1 per 20 environmental samples)

\section{- Chemical samples}

- Field duplicates for grab samples (1 per 20 environmental samples)

- Trip blanks (1 per sample cooler containing VOC environmental samples)

Additional QC samples may be submitted based on site conditions at the discretion of the Task Manager or Site Supervisor. Field QC samples must be analyzed using the same analytical procedures implemented for associated environmental samples. Additional details regarding field QC samples are available in the Soils QAP (NNSA/NSO, 2012b). 


\subsection{Laboratory/Analytical Quality Assurance}

As stated in the DQOs (see Appendix A) and in the Soils QAP (NNSA/NSO, 2012b), data used for making DQO decisions will be evaluated for data quality. The Soils QAP defines and establishes data quality criteria that are evaluated in three defined steps:

1. Data Verification

2. Data Validation

3. Data Quality Assessment

Data verification will be performed on all chemical and radiological laboratory data for data quality in accordance with company-specific procedures. The data will be reviewed to evaluate the completeness, correctness, and conformance of each dataset. This verification will include a review of sample collection, handling and transfer, and documentation associated with sampling and analytical activities

Data validation will be performed on environmental sample results to determine the analytical quality of datasets. Data validation criteria will be based upon the DQOs and the intended use of the data. Validation will include an evaluation of method and contract compliance, data calculations, QC and calibration verifications, raw data, and data generation methods. Validation may include qualifying data that restrict or limit use of such data. The data validation includes an evaluation of the DQI criteria for the following:

1. Precision

2. Accuracy/bias

3. Representativeness

4. Comparability

5. Completeness

6. Sensitivity

Data that do not meet the DQI criteria will be evaluated for usability in the investigation report.

A data quality assessment (DQA) will be performed to determine whether the analytical data meet DQO performance criteria. The DQA considers how the data relate to decisions to be made, the intended use of the data, and whether data are suitable for making those decisions. The results of this assessment will be documented in the investigation report. If the DQOs were not met, corrective actions will be evaluated, selected, and implemented (e.g., refine CSM or resample to fill data gaps). 


\subsection{Duration and Records Availability}

\subsection{Duration}

Field and analytical activities will require approximately 160 days to complete.

\subsection{Records Availability}

Historical information and documents referenced in this plan are retained in the NNSA/NFO activity files in Las Vegas, Nevada, and can be obtained through written request to the NNSA/NFO Soils Activity Lead. This document is available in the DOE public reading facilities located in Las Vegas and Carson City, Nevada, or by contacting the appropriate DOE Soils Activity Lead. 


\subsection{References}

ASTM, see ASTM International.

ASTM International. 1995 (reapproved 2010). Standard Guide for Risk-Based Corrective Action Applied at Petroleum Release Sites, ASTM E1739 - 95(2010)e1. West Conshohocken, PA.

Buchheit, Jr., R., and C. Marianno. 2005. "Update of Technology for Use with FIDLER Detectors.” In Radiation Protection Management, Vol. 22(4): pp. 19-22.

CFR, see Code of Federal Regulations.

Code of Federal Regulations. 2012a. Title 40 CFR, Parts 260 to 282, “Hazardous Waste Management System.” Washington, DC: U.S. Government Printing Office.

Code of Federal Regulations. 2012b. Title 40 CFR, Part 761, "Polychlorinated Biphenyls (PCBs) Manufacturing, Processing, Distribution in Commerce, and Use Prohibitions.” Washington, DC: U.S. Government Printing Office.

DNA, see Defense Nuclear Agency.

DOE, see U.S. Department of Energy.

DOE/NV, see U.S. Department of Energy, Nevada Operations Office.

DRI, see Desert Research Institute.

Defense Nuclear Agency. 1979. Compilation of Local Fallout Data from Test Detonations 1945-1962 Extracted from DASA 1251, Volume I - Continental U.S. Tests, DNA 1251-1-EX. Washington, DC.

Desert Research Institute. 1988. CERCLA Preliminary Assessment of DOE's Nevada Operations Office Nuclear Weapons Testing Areas. April. Las Vegas, NV.

EPA, see U.S. Environmental Protection Agency.

ERDA, see Energy Research and Development Administration.

Energy Research and Development Administration. 1977. Final Environmental Impact Statement, Nevada Test Site, Nye County, Nevada, ERDA-1551. Washington, DC.

FFACO, see Federal Facility Agreement and Consent Order. 
Federal Facility Agreement and Consent Order. 1996 (as amended March 2010). Agreed to by the State of Nevada; U.S. Department of Energy, Environmental Management; U.S. Department of Defense; and U.S. Department of Energy, Legacy Management. Appendix VI, which contains the Soils Sites Strategy, was last modified May 2011, Revision No. 4.

Fenelon, J.M., D.S. Sweetkind, and R.J. Laczniak. 2010. Groundwater Flow Systems at the Nevada Test Site, Nevada: A Synthesis of Potentiometric Contours, Hydrostratigraphy, and Geologic Structures, Professional Paper 1771. Reston, VA: U.S. Geological Survey.

Frizzell, V.A., and J. Shulters. 1990. Geologic Map of the Nevada Test Site, Southern Nevada, Map I-2046. Denver, CO: U.S. Geological Survey.

Gilbert, R.O., E.H. Essington, D.N. Brady, P.G. Doctor, and L.L Eberhardt. 1977. "Statistical Activities during 1976 and the Design and Initial Analysis of Nuclear Site Studies.” In Transuranics in Desert Ecosystems, NVO-181. pp. 331-366. November. Las Vegas, NV: U.S. Department of Energy, Nevada Operations Office.

Laczniak, R.J., J.C. Cole, D.A. Sawyer, and D.A. Trudeau. 1996. Summary of Hydrogeologic Controls on Ground-Water Flow at the Nevada Test Site, Nye County, Nevada, Water-Resources Investigations Report 96-4109. Carson City, NV: U.S. Geological Survey.

McArthur, R.D., and J.F. Kordas. 1983. Radionuclide Inventory and Distribution Program: The Galileo Area, DOE/NV/10162-14; Publication No. 45035. Las Vegas, NV: Desert Research Institute, Water Resources Center.

McArthur, R.D., and J.F. Kordas. 1985. Nevada Test Site Radionuclide Inventory and Distribution Program: Report \#2. Areas 2 and 4, DOE/NV/10162-20; Publication No. 45041. Las Vegas, NV: Desert Research Institute, Water Resources Center.

McArthur, R.D., and S.W. Mead. 1987. Nevada Test Site Radionuclide Inventory and Distribution Program: Report \#3. Areas 3, 7, 8, 9, and 10, DOE/NV/10384-15; Publication No. 45056. Las Vegas, NV: Desert Research Institute, Water Resources Center.

Moore, J., Science Applications International Corporation. 1999. Memorandum to M. Todd (SAIC) titled "Background Concentrations for NTS and TTR Soil Samples,” 3 February. Las Vegas, NV: IT Corporation.

NAC, see Nevada Administrative Code.

NBMG, see Nevada Bureau of Mines and Geology.

NDEP, see Nevada Division of Environmental Protection.

N-I GIS, see Navarro-Intera Geographic Information Systems. 
NNSA/NSO, see U.S. Department of Energy, National Nuclear Security Administration Nevada Site Office.

NNSA/NV, see U.S. Department of Energy, National Nuclear Security Administration Nevada Operations Office.

NSTec, see National Security Technologies, LLC.

National Security Technologies, LLC. 2012. NNSS Area 09-AMS 50’ Aerial Survey, April 19 \& 25, 2012. Las Vegas, NV: Remote Sensing Laboratory.

Navarro-Intera Geographic Information Systems. 2013. ESRI ArcGIS Software.

Nevada Administrative Code. 2012a. NAC 445A.227, “Contamination of Soil: Order by Director for Corrective Action; Factors To Be Considered in Determining Whether Corrective Action Required.” Carson City, NV. As accessed at http://www.leg.state.nv.us/nac on 12 April 2013.

Nevada Administrative Code. 2012b. NAC 445A.22705, “Contamination of Soil: Evaluation of Site by Owner or Operator; Review of Evaluation by Division.” Carson City, NV. As accessed at http://www.leg.state.nv.us/nac on 12 April 2013.

Nevada Bureau of Mines and Geology. 1998. Mineral and Energy Resource Assessment of the Nellis Air Force Range, Open-File Report 98-1. Reno, NV.

Nevada Division of Environmental Protection. 2006 (as amended August 2000). Class III Solid Waste Disposal Site for Hydrocarbon Burdened Soils, Area 6 of the NTS, Permit SW 13-097-02, Rev. 7. Carson City, NV.

REECo, see Reynolds Electrical \& Engineering Co., Inc.

Reynolds Electrical \& Engineering Co., Inc. 1956. Report on Decontamination of Areas 9B and 9C. Las Vegas, NV.

Reynolds Electrical \& Engineering Co., Inc. 1982. Photograph Album Index (1958 -1976). Photographs 621-9 and 1384-6. Las Vegas, NV.

Reynolds Electrical \& Engineering Co., Inc. 1985. Nevada Test Site Radioactive Waste Consolidation Project Fiscal Year 1985 Completion Report. Las Vegas, NV.

Reynolds Electrical \& Engineering Co., Inc. Date Unknown. Decontamination Report Area 9. Las Vegas, NV.

Riedhauser, S.R. 1999. A Radiological Characterization of the Kiwi-I Vehicle, DOE/NV/11718--298. Las Vegas, NV: Bechtel Nevada, Remote Sensing Laboratory. 
Soule', D.A. 2006. Climatology of the Nevada Test Site, SORD Technical Memorandum 2006-03. Silver Spring, MD: National Oceanographic and Atmospheric Administration, Air Resources Laboratory.

TSA Systems, see TSA Systems, Ltd.

Tamura, T. 1977. "Plutonium Distribution in a Desert Pavement.Desert Mound Soil System in Area 11.” In Environmental Plutonium on the Nevada Test Site and Environs, NVO-171. June. Las Vegas, NV: Energy Research and Development Administration, Nevada Applied Ecology Group.

TSA Systems, Ltd. 2005. PRM-470CGN Operations Manual, Doc. \#5200, Rev. A. Longmont, CO.

USGS, see U.S. Geological Survey.

U.S. Department of Energy, National Nuclear Security Administration Nevada Operations Office. 2002. Nevada Test Site Orthophoto Site Atlas, DOE/NV/11718--604. Aerial photos acquired Summer 1998. Prepared by Bechtel Nevada. Las Vegas, NV.

U.S. Department of Energy, National Nuclear Security Administration Nevada Site Office. 2012a. Nevada National Security Site Waste Acceptance Criteria, DOE/NV-325-Rev. 9. Las Vegas, NV.

U.S. Department of Energy, National Nuclear Security Administration Nevada Operations Office. 2012b. Soils Activity Quality Assurance Plan, Rev. 0, DOE/NV--1478. Las Vegas, NV.

U.S. Department of Energy, National Nuclear Security Administration Nevada Site Office. 2012c. Soils Risk-Based Corrective Action Evaluation Process, Rev. 0, DOE/NV--1475. Las Vegas, NV.

U.S. Department of Energy, Nevada Operations Office. 1992. Remedial Investigation and Feasibility Study for the Plutonium Contaminated Soils at Nevada Test Site, Nellis Air Force Range and Tonopah Test Range. April. Las Vegas, NV.

U.S. Department of Energy, Nevada Operations Office. 1996. Final Environmental Impact Statement for the Nevada Test Site and Off-Site Locations in the State of Nevada, DOE/EIS 0243. Las Vegas, NV.

U.S. Department of Energy, Nevada Operations Office. 1998. Nevada Test Site Resource Management Plan, DOE/NV--518. Las Vegas, NV.

U.S. Department of Energy, Nevada Operations Office. 2000. United States Nuclear Tests, July 1945 through September 1992, DOE/NV--209-Rev 15. Las Vegas, NV. 
U.S. Environmental Protection Agency. 2013a. Pacific Southwest, Region 9: Regional Screening Levels (Formerly PRGs), Screening Levels for Chemical Contaminants. As accessed at http://www.epa.gov/region9/superfund/prg on 12 April. Prepared by EPA Office of Superfund and Oak Ridge National Laboratory.

U.S. Geological Survey. 2013. “Groundwater Levels for Nevada.” As accessed at http://nwis.waterdata.usgs.gov/nv/nwis/gwlevels on 12 April.

Yu, C., A.J. Zielen, J.-J. Cheng, D.J. LePoire, E. Gnanapragasam, S. Kamboj, J. Arnish, A. Wallo III, W.A. Williams, and H. Peterson. 2001. User's Manual for RESRAD Version 6, ANL/EAD-4. Argonne, IL: Argonne National Laboratory, Environmental Assessment Division. (Version 6.5 released in October 2009.)

Yucel, V., National Security Technologies, LLC. 2009. Personal communication to R.L. Kidman (N-I) regarding PET data, 30 April. Las Vegas, NV. 


\section{Appendix A}

\section{Data Quality Objectives}




\section{A.1.0 Introduction}

The DQO process described in this appendix is a seven-step strategic systematic planning method used to plan data collection activities and define performance criteria for the CAU 571, Area 9 Yucca Flat Plutonium Dispersion Sites, field investigation. DQOs are designed to ensure that the data collected will provide sufficient and reliable information to identify, evaluate, and technically defend recommended corrective actions (i.e., no further action, closure in place, or clean closure). Existing information about the nature and extent of contamination at the CASs in CAU 571 is insufficient to evaluate and select preferred corrective actions; therefore, a CAI will be conducted.

The CAU 571 CAI will be based on the DQOs presented in this appendix as developed by NDEP and NNSA/NFO representatives. The seven steps of the DQO process presented in Sections A.2.0 through A.8.0 were developed in accordance with Guidance on Systematic Planning Using the Data Quality Objectives Process (EPA, 2006).

In general, the procedures used in the DQO process provide the following:

- A method to establish performance or acceptance criteria, which serve as the basis for designing a plan for collecting data of sufficient quality and quantity to support the goals of a study.

- Criteria that will be used to establish the final data collection design, such as

- the nature of the problem that has initiated the study and a conceptual model of the environmental hazard to be investigated;

- the decisions or estimates that need to be made, and the order of priority for resolving them;

- the type of data needed; and

- an analytic approach or decision rule that defines the logic for how the data will be used to draw conclusions from the study findings.

- Acceptable quantitative criteria on the quality and quantity of the data to be collected, relative to the ultimate use of the data. 
- A data collection design that will generate data meeting the quantitative and qualitative criteria specified. A data collection design specifies the type, number, location, and physical quantity of samples and data, as well as the QA and QC activities that will ensure that sampling design and measurement errors are managed sufficiently to meet the performance or acceptance criteria specified in the DQOs. 


\section{A.2.0 Step 1 - State the Problem}

Step 1 of the DQO process defines the problem that requires study, identifies the planning team, and develops a conceptual model of the environmental hazard to be investigated.

The problem statement for CAU 571 is as follows: "Existing information on the nature and extent of potential contamination is insufficient to evaluate and recommend CAAs for the CASs in CAU 571.”

\section{A.2.1 Planning Team Members}

The DQO planning team consists of representatives from NDEP and NNSA/NFO. The DQO planning team met on March 6, 2013, for the DQO meeting.

\section{A.2.2 Conceptual Site Model}

The CSM is used to organize and communicate information about site characteristics. It reflects the best interpretation of available information at a point in time. The CSM is a primary vehicle for communicating assumptions about release mechanisms, potential migration pathways, or specific constraints. It provides a summary of how and where contaminants are expected to move and what impacts such movement may have. It is the basis for assessing how contaminants could reach receptors both in the present and future. The CSM describes the most probable scenario for current conditions at each site and defines the assumptions that are the basis for identifying appropriate sampling strategy and data collection methods. An accurate CSM is important as it serves as the basis for all subsequent inputs and decisions throughout the DQO process.

The CSM was developed for CAU 571 using information from the physical setting, potential contaminant sources, release information, historical background information, knowledge from similar sites, and physical and chemical properties of the potentially affected media and COPCs.

The CSM consists of the following:

- Potential contaminant releases, including media subsequently affected

- $\quad$ Release mechanisms (the conditions associated with the release) 
- Potential contaminant source characteristics, including contaminants suspected to be present and contaminant-specific properties

- Site characteristics, including physical, topographical, and meteorological information

- Migration pathways and transport mechanisms that describe the potential for migration and where the contamination may be transported

- The locations of points of exposure where individuals or populations may come in contact with a COC associated with a CAS

- Routes of exposure where contaminants may enter the receptor

If additional elements are identified during the CAI that are outside the scope of the CSM, the situation will be reviewed and a recommendation will be made as to how to proceed. In such cases, NDEP will be notified and given the opportunity to comment on, or concur with, the recommendation.

The applicability of the CSM to each release source is summarized in Table A.2-1 and discussed below. Table A.2-1 provides information on CSM elements that will be used throughout the remaining steps of the DQO process. Figure A.2-1 depicts a representation of the conceptual pathways to receptors from CAU 571 sources. Figure A.2-2 depicts a graphical representation of the CSM.

\section{A.2.2.1 Release Sources}

The following identifies the release sources (DOE/NV, 2000) specific to CAU 571:

- Post, a weapons-related test, was conducted on April 9, 1955, as part of Operation Teapot. The test consisted of a primarily plutonium and uranium device that was detonated atop a $300-\mathrm{ft}$ tower. The yield from the test was 2 kilotons.

- Juno, a safety experiment, was conducted on October 24, 1958, as part of Operation Hardtack II. The test consisted of a primarily plutonium device that was detonated in a gravel gertie covered with $20 \mathrm{ft}$ of gravel. The yield from the experiment was 1.7 tons.

- Vesta, a safety experiment, was conducted on October 17, 1958, as part of Operation Hardtack II. The test consisted of a primarily plutonium and uranium device that was detonated in a gravel gertie covered with $20 \mathrm{ft}$ of gravel. The yield from the experiment was 24 tons. 
Table A.2-1

CSM Description of Elements for Each Study Group in CAU 571

\begin{tabular}{|c|c|c|c|c|c|}
\hline $\begin{array}{l}\text { Study Group } \\
\text { Identifier and } \\
\text { Description }\end{array}$ & $\begin{array}{l}\text { Study Group 1, } \\
\text { Atmospheric } \\
\text { Release }\end{array}$ & \begin{tabular}{|l|} 
Study Group 2, \\
Subsurface \\
Contamination
\end{tabular} & $\begin{array}{l}\text { Study Group 3, } \\
\text { Windrows }\end{array}$ & $\begin{array}{l}\text { Study Group 4, } \\
\text { Drainage }\end{array}$ & $\begin{array}{l}\text { Study Group 5, } \\
\text { Other }\end{array}$ \\
\hline Site Status & \multicolumn{5}{|c|}{ Sites are inactive and/or abandoned } \\
\hline Exposure Scenario & \multicolumn{5}{|c|}{ Occasional Use } \\
\hline $\begin{array}{l}\text { Sources of Potential } \\
\text { Soil Contamination }\end{array}$ & \multicolumn{4}{|c|}{$\begin{array}{l}\text { Atmospheric deposition of radionuclides from two weapons-related tests and } \\
\text { two safety experiments; subsequent reworking and windrowing of the original } \\
\text { surface soil; movement of the atmospheric release radionuclides in drainages }\end{array}$} & $\begin{array}{l}\text { Debris (e.g., lead, } \\
\text { batteries, drums), } \\
\text { asphalt pile, } \\
\text { northern CA }\end{array}$ \\
\hline $\begin{array}{l}\text { Location of } \\
\text { Contamination/ } \\
\text { Release Point }\end{array}$ & Surface soil & $\begin{array}{l}\text { Surface and } \\
\text { subsurface soil }\end{array}$ & $\begin{array}{l}\text { Surface } \\
\text { windrowed soil }\end{array}$ & $\begin{array}{l}\text { Surface and } \\
\text { shallow } \\
\text { subsurface soil }\end{array}$ & $\begin{array}{l}\text { Surface and } \\
\text { shallow } \\
\text { subsurface soil }\end{array}$ \\
\hline Amount Released & \multicolumn{5}{|c|}{ Unknown } \\
\hline Affected Media & \multicolumn{5}{|c|}{ Surface, shallow subsurface, and subsurface soil; drainage sediments } \\
\hline $\begin{array}{l}\text { Potential } \\
\text { Contaminants }\end{array}$ & \multicolumn{4}{|c|}{$\begin{array}{l}\text { Isotopic } \mathrm{Pu} \text {, isotopic } \mathrm{U} \text {, isotopic } \mathrm{Am} \text {, other associated radionuclides, } \\
\text { and fission products }\end{array}$} & $\begin{array}{l}\text { Isotopic } \mathrm{Pu}, \\
\text { isotopic } \mathrm{U}, \\
\text { isotopic } \mathrm{Am}, \\
\text { other associated } \\
\text { radionuclides, } \\
\text { and fission } \\
\text { products; lead }\end{array}$ \\
\hline $\begin{array}{c}\text { Transport } \\
\text { Mechanisms }\end{array}$ & \multicolumn{5}{|c|}{$\begin{array}{l}\text { Percolation of precipitation through subsurface media serves as the major driving force for } \\
\text { migration of contaminants. Surface water runoff may provide for the transportation of some } \\
\text { contaminants within or outside the footprints of the study groups (i.e., drainages). }\end{array}$} \\
\hline Migration Pathways & \multicolumn{5}{|c|}{$\begin{array}{l}\text { For subsurface migration, vertical transport expected to dominate over lateral transport due to } \\
\text { small surface gradients. For surface migration, lateral transport expected to dominate over vertical } \\
\text { due to large PET demands and low precipitation amounts. The large depth to the uppermost } \\
\text { aquifer precludes groundwater as a significant pathway. }\end{array}$} \\
\hline $\begin{array}{l}\text { Lateral and Vertical } \\
\text { Extent of } \\
\text { Contamination }\end{array}$ & \multicolumn{5}{|c|}{$\begin{array}{l}\text { Contamination, if present, is expected to be contiguous to the release points. Concentrations are } \\
\text { expected to decrease with distance and depth from the source. Lateral and vertical extent of } \\
\text { contamination exceeding FALs is assumed to be within the spatial boundaries. }\end{array}$} \\
\hline Exposure Pathways & \multicolumn{5}{|c|}{$\begin{array}{l}\text { The potential for contamination exposure is limited to industrial and construction workers, and } \\
\text { military personnel conducting training. These human receptors may be exposed to COPCs } \\
\text { through oral ingestion or inhalation of, or dermal contact (absorption) with soil and/or debris due to } \\
\text { inadvertent disturbance of these materials, or irradiation by radioactive materials. }\end{array}$} \\
\hline
\end{tabular}




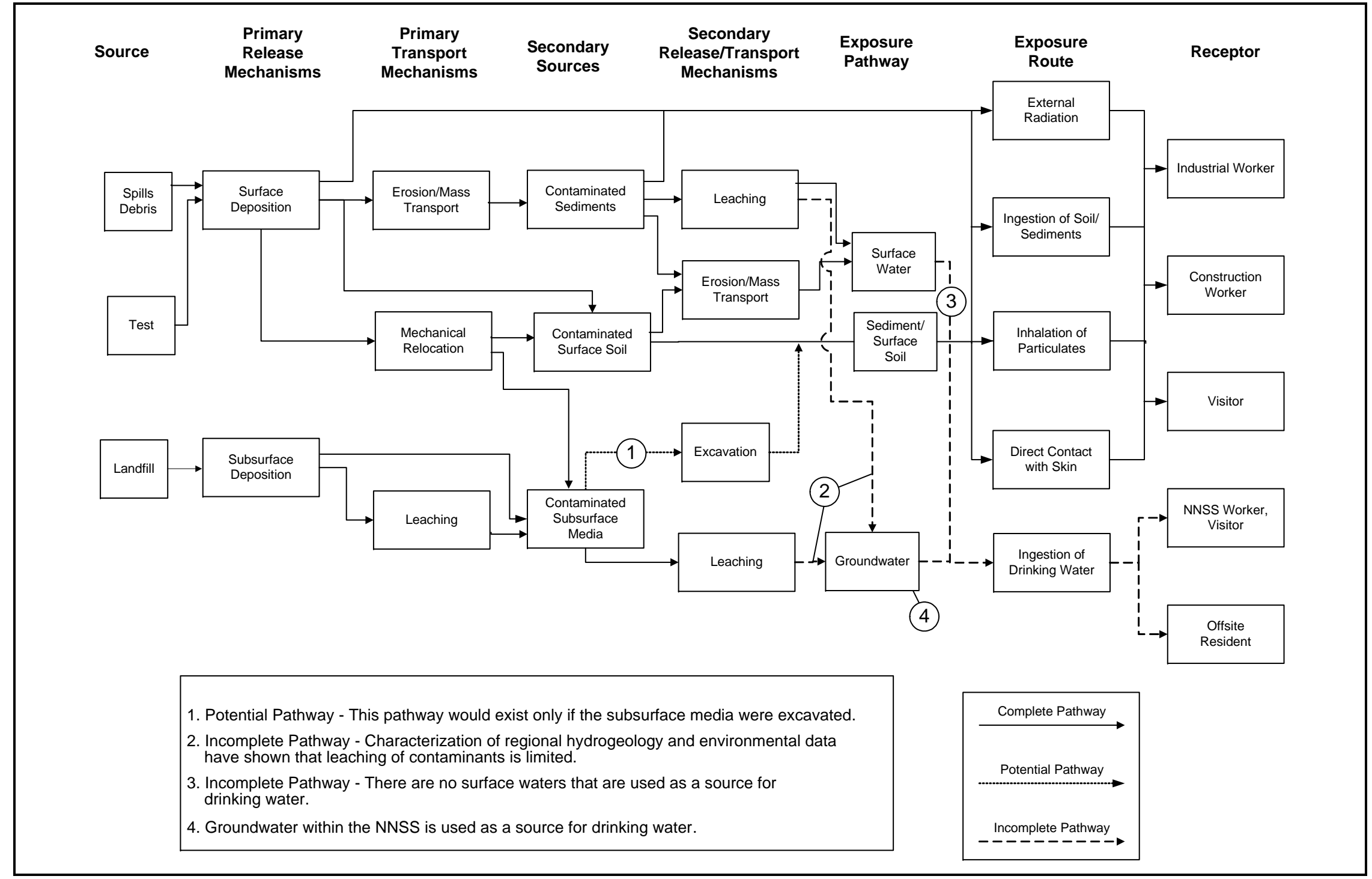

Figure A.2-1

CAU 571 CSM Pathways to Receptors

\section{UNCONTROLLED When Printed}




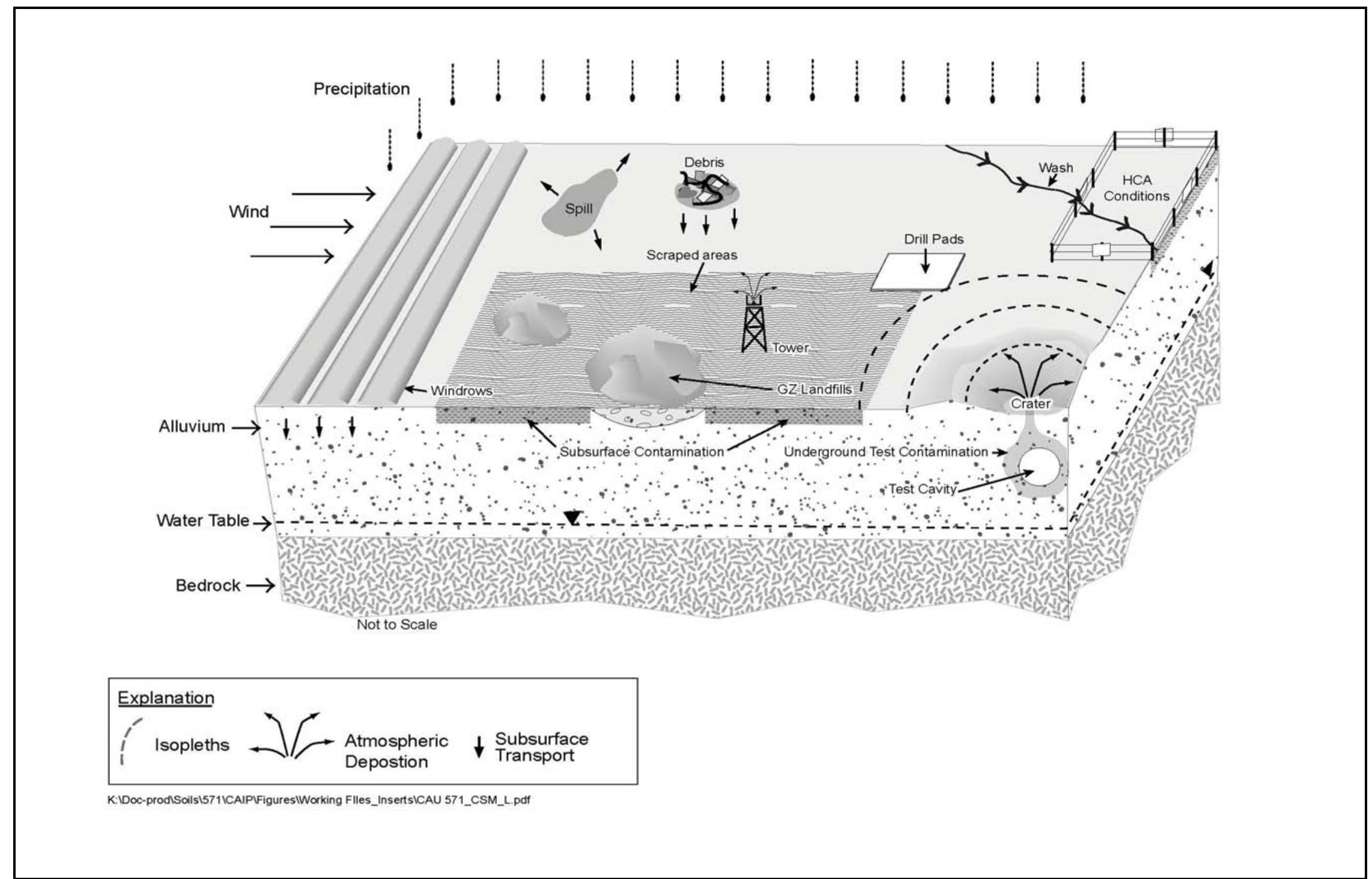

Figure A.2-2

CSM for CAU 571 
- Mazama, a weapons-related test, was conducted on October 29, 1958, as part of Operation Hardtack II. The test consisted of a primarily plutonium device that was detonated in a wooden cab atop a 50-ft steel tower. There was no yield.

- Debris, either contaminated as a result of the atmospheric releases or consisting of hazardous contaminants, is present in the test areas that could be PSM. This PSM consists of items such as lead, batteries, drums, and asphalt pile.

The most likely locations of the contamination and releases to the environment are the soils directly below or adjacent to the CSM's surface and subsurface components (i.e., soils impacted by fallout).

To facilitate site investigation and the evaluation of DQO decisions for different CSM components, the releases at each CAS were classified into one of the following study groups:

- Study Group 1, Atmospheric Release: This release category is specific to the atmospheric deposition of radionuclide contamination from weapons-related and safety experiments. The release is composed mainly of fission and activated products from the weapons tests and unfissioned nuclear material (from the scattering of nuclear material due to the detonation of chemical explosives) from safety tests onto the soil surface that has not been displaced through excavation or migration. The contamination associated with this type of release will be limited to the top $5 \mathrm{~cm}$ of soil. Atmospheric releases of radionuclides that have been distributed at the NNSS from nuclear testing have been found to be concentrated in the upper $5 \mathrm{~cm}$ of undisturbed soil (McArthur and Kordas, 1983 and 1985; Gilbert et al., 1977; Tamura, 1977).

- Study Group 2, Subsurface Contamination: This group investigates radionuclide contamination that was initially deposited on the soil surface but has subsequently been displaced through mechanical means (e.g., scraping, reworking of soil for subsequent activities in the area).

- Study Group 3, Windrows: This group investigates radionuclide contamination that was initially deposited on the soil surface but was subsequently scraped into rows. A portion of the original windrows exists, while some of the windrows have been disturbed.

- Study Group 4, Drainage: This group investigates radionuclide contamination that was initially deposited onto the soil surface but has subsequently been displaced through erosion.

- Study Group 5, Other: This group investigates any chemical or radiological contamination associated with debris and/or spills. The debris will be evaluated for PSM, and spills will be evaluated based on the presence of biasing factors such as discoloration or elevated instrument readings. Additionally, other features that require investigation (e.g., contaminated areas with an unknown release, piles/mounds) will be evaluated for radiological and/or chemical contamination in this study group. 


\section{A.2.2.2 Potential Contaminants}

The release-specific COPCs are defined as the contaminants reasonably expected at the site that could contribute to a dose or risk exceeding FALs. Based on the nature of the releases identified in Section 2.4 and previous investigation results presented in Section 2.5, the following contaminants could reasonably be suspected to be present at CAU 571: U-234, -235/236, and -238; Pu-238, -239/240, and -241; Cs-137; and Am-241. Additionally, lead is a COPC at Study Group 5. Table A.2-2 contains the COPCs listed by Study Group. These COPCs were identified during the planning process through the review of site history, process knowledge, personal interviews, past investigation efforts (where available), and inferred activities associated with the study groups (including those that may be discovered during the investigation).

Table A.2-2

Contaminants of Potential Concern ${ }^{\mathrm{a}}$

\begin{tabular}{||c|c|c|c|c|c||}
\hline COPCs & Study Group 1 & Study Group 2 & Study Group 3 & Study Group 4 & Study Group 5 \\
\hline \hline \multicolumn{7}{|c||}{ Inorganic COPCs } \\
\hline \hline Lead & -- & -- & -- & -- & $X$ \\
\hline \hline \multicolumn{7}{|c|}{ Radionuclide COPCs } \\
\hline \hline U-234 & $\mathrm{X}$ & $\mathrm{X}$ & $\mathrm{X}$ & $\mathrm{X}$ & $\mathrm{X}$ \\
\hline $\mathrm{U}-235 / 236$ & $\mathrm{X}$ & $\mathrm{X}$ & $\mathrm{X}$ & $\mathrm{X}$ & $\mathrm{X}$ \\
\hline $\mathrm{U}-238$ & $\mathrm{X}$ & $\mathrm{X}$ & $\mathrm{X}$ & $\mathrm{X}$ & $\mathrm{X}$ \\
\hline $\mathrm{Pu}-238$ & $\mathrm{X}$ & $\mathrm{X}$ & $\mathrm{X}$ & $\mathrm{X}$ & $\mathrm{X}$ \\
\hline $\mathrm{Pu}-239 / 240$ & $\mathrm{X}$ & $\mathrm{X}$ & $\mathrm{X}$ & $\mathrm{X}$ & $\mathrm{X}$ \\
\hline $\mathrm{Pu}-241$ & $\mathrm{X}$ & $\mathrm{X}$ & $\mathrm{X}$ & $\mathrm{X}$ & $\mathrm{X}$ \\
\hline $\mathrm{Cs}-137$ & $\mathrm{X}$ & $\mathrm{X}$ & $\mathrm{X}$ & $\mathrm{X}$ & $\mathrm{X}$ \\
\hline $\mathrm{Am}-241$ & $\mathrm{X}$ & $\mathrm{X}$ & $\mathrm{X}$ & $\mathrm{X}$ & $\mathrm{X}$ \\
\hline \hline
\end{tabular}

${ }^{a}$ The COPCs are the constituents that, based on process knowledge and historical documentation, are likely to be present.

$X=$ COPC associated with this study group

$--=$ COPC not associated with this study group

Additional COPCs for Study Group 5 may be discovered during the investigation. Specific COPCs (and the analyses requested) will be determined for newly discovered releases based on the nature of the release (e.g., stains). 
Although not suspected to be present, analysis for other COPCs will be performed to eliminate the possibility of their presence due to an incomplete history of site testing operations as discussed in Section A.2.2.2. These COPCs will be reported by the analytical methods identified in Table A.2-3 for environmental samples taken at each of the sites. The analytes reported for each analytical method are listed in Table A.2-4.

Table A.2-3

Analyses Required by Study Group ${ }^{a}$

\begin{tabular}{|c|c|c|c|c|c|}
\hline Analyses & Study Group 1 & Study Group 2 & Study Group 3 & Study Group 4 & Study Group $5^{b}$ \\
\hline \multicolumn{6}{|c|}{ Organic COPCs } \\
\hline VOCs & -- & -- & -- & -- & $\bar{x}$ \\
\hline SVOCs & -- & -- & -- & -- & $x$ \\
\hline Dioxins & -- & -- & $X^{c}$ & -- & -- \\
\hline PCBs & -- & -- & $x$ & $x$ & -- \\
\hline \multicolumn{6}{|c|}{ Inorganic COPCs } \\
\hline RCRA Metals & -- & - & - & -- & $\bar{x}$ \\
\hline Chromium VI & -- & -- & -- & -- & $\mathrm{x}$ \\
\hline \multicolumn{6}{|c|}{ Radionuclide COPCs } \\
\hline $\begin{array}{c}\text { Gamma } \\
\text { Spectroscopy }\end{array}$ & $x$ & $x$ & $x$ & $x$ & $x$ \\
\hline Isotopic U & $x$ & $x$ & $x$ & $x$ & $x$ \\
\hline Isotopic Pu & $\mathrm{x}$ & $\mathrm{x}$ & $\mathrm{x}$ & $\mathrm{x}$ & $\mathrm{x}$ \\
\hline Isotopic Am & $x$ & $x$ & $x$ & $x$ & $x$ \\
\hline Pu-241 & $\mathrm{x}$ & $\mathrm{x}$ & $\mathrm{x}$ & $\mathrm{x}$ & $\mathrm{x}$ \\
\hline
\end{tabular}

${ }^{a}$ The analytical method has been determined based on the site-specific COPCs. Analytical method numbers are shown in Table A.2-4.

${ }^{b}$ Analyses will be specific to the investigative feature being sampled.

'One sample will be selected for dioxins.

$X=$ Required analytical method as described in Soils QAP (NNSA/NSO, 2012a)

-- = Not required 
Table A.2-4

Analytes Reported Per Method

\begin{tabular}{|c|c|c|c|c|c|c|}
\hline \multirow{2}{*}{\multicolumn{2}{|c|}{$\frac{\text { VOCs }}{\text { Method 8260 }}$}} & \multirow{2}{*}{\multicolumn{2}{|c|}{ 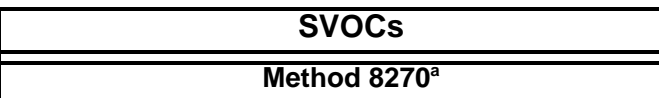 }} & Metals & \multicolumn{2}{|c|}{ Radionuclides } \\
\hline & & & & Method $6010^{\mathrm{a}}$ & Gamma Spectroscopy & Isotopic -U \\
\hline 1,1,1,2-Tetrachloroethane & Carbon tetrachloride & 1,4-Dioxane & Bis(2-ethylhexyl)phthalate & Arsenic & Method Ga-01 & Method U-02 \\
\hline 1,1,1-Trichloroethane & Chlorobenzene & 2,3,4,6-Tetrachlorophenol & Butyl benzyl phthalate & Barium & Ac-228 & U-234 \\
\hline 1,1,2,2-Tetrachloroethane & Chloroethane & 2,4,5-Trichlorophenol & Carbazole & Beryllium & Ag-108m & U-235 \\
\hline 1,1,2-Trichloroethane & Chloroform & 2,4,6-Trichlorophenol & Chrysene & Cadmium & Al-26 & U-238 \\
\hline 1,1-Dichloroethane & Chloromethane & 2,4-Dimethylphenol & Di-n-butyl phthalate & Chromium & Am-241 & \\
\hline 1,1-Dichloroethene & Chloroprene & 2,4-Dinitrotoluene & Di-n-octyl phthalate & Lead & $\mathrm{Cm}-243$ & Isotopic Pu \\
\hline 1,2,4-Trichlorobenzene & cis-1,2-Dichloroethene & 2-Chlorophenol & Dibenzo(a,h)anthracene & Selenium & Co-60 & MethodPu-02 \\
\hline $\begin{array}{l}\text { 1,2,4-Trimethylbenzene } \\
\text { 1,2-Dibromo-3-chloropropane }\end{array}$ & $\begin{array}{l}\text { Dibromochloromethane } \\
\text { Dichlorodifluoromethane }\end{array}$ & $\begin{array}{l}\text { 2-Methylnaphthalene } \\
\text { 2-Methylphenol }\end{array}$ & $\begin{array}{l}\text { Dibenzofuran } \\
\text { Dimethyl phthalate }\end{array}$ & Silver & $\begin{array}{l}\text { Cs-137 } \\
\text { Eu-152 }\end{array}$ & \begin{tabular}{|l|} 
Pu-238 \\
Pu-239/240
\end{tabular} \\
\hline 1,2-Dichlorobenzene & Ethyl methacrylate & 2-Nitrophenol & Fluoranthene & Method $7196^{\mathrm{a}}$ & Eu-154 & \\
\hline 1,2-Dichloroethane & Ethylbenzene & 3-Methylphenol' (m-cresol) & Fluorene & Chromium VI & Eu-155 & \\
\hline 1,2-Dichloropropane & Isobutyl alcohol & 4-Methylphenol' (p-cresol) & Hexachlorobenzene & & $K-40$ & Lab-Specific Methods $^{d}$ \\
\hline 1,3,5-Trimethylbenzene & Isopropylbenzene & 4-Chloroaniline & Hexachlorobutadiene & PCBs & $\mathrm{Nb}-94$ & Pu-241 \\
\hline 1,3-Dichlorobenzene & Methacrylonitrile & 4-Nitrophenol & Hexachloroethane & Method 8082 & $\mathrm{~Pa}-233$ & \\
\hline 1,4-Dichlorobenzene & Methyl methacrylate & Acenaphthene & Indeno(1,2,3-cd)pyrene & Aroclor 1016 & $\mathrm{~Pb}-212$ & \\
\hline 2-Butanone & Methylene chloride & Acenaphthylene & n-Nitroso-di-n-propylamine & Aroclor 1221 & $\mathrm{~Pb}-214$ & \\
\hline 2-Chlorotoluene & n-Butylbenzene & Aniline & Naphthalene & Aroclor 1232 & Th-229 & \\
\hline 2-Hexanone & n-Propylbenzene & Anthracene & Nitrobenzene & Aroclor 1242 & Th-234 & \\
\hline 4-Isopropyltoluene & sec-Butylbenzene & Benzo(a)anthracene & Pentachlorophenol & Aroclor 1248 & TI-208 & \\
\hline 4-Methyl-2-pentanone & Styrene & Benzo(a)pyrene & Phenanthrene & Aroclor 1254 & U-235 & \\
\hline Acetone & tert-Butylbenzene & Benzo(b)fluoranthene & Phenol & Aroclor 1260 & & \\
\hline Acetonitrile & Tetrachloroethene & Benzo(g,h,i)perylene & Pyrene & Aroclor 1268 & Tsotopic Am & \\
\hline Allyl chloride & Toluene & Benzo(k)fluoranthene & Pyridine & & Method Am-01" & \\
\hline Benzene & Total xylenes & Benzoic acid & Diethyl phthalate & Dioxins & Am-241 & \\
\hline Bromodichloromethane & Trichloroethene & Benzyl alcohol & & Method 8290 & Am-243 & \\
\hline Bromoform & Trichlorofluoromethane & & & 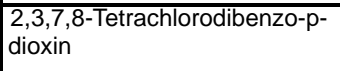 & & \\
\hline $\begin{array}{l}\text { Bromomethane } \\
\text { Carbon disulfide }\end{array}$ & $\begin{array}{l}\text { Vinyl acetate } \\
\text { Vinyl chloride }\end{array}$ & & & & & \\
\hline
\end{tabular}

${ }^{\mathrm{a} T e s t}$ Methods for Evaluating Solid Waste, Physical/Chemical Methods (EPA, 2013b)

${ }^{\mathrm{b}}$ The Procedures Manual of the Environmental Measurements Laboratory, which includes HASL-300 Methods (DOE, 1997)

"May be reported as 3,4-Methylphenol or m,p-cresol.

${ }^{\mathrm{d}}$ The most current EPA, DOE, or equivalent accepted analytical method may be used, including Laboratory Standard Operating Procedures approved by the contractor in accordance with industry standards and the contractor's SOW requirements.

$\mathrm{HASL}=$ Health and Safety Laboratory SOW $=$ Statement of Work
Ac $=$ Actinium
$\mathrm{Ag}=$ Silve
$\mathrm{Cm}=$ Curium

$\mathrm{Al}=$ Aluminum
$\mathrm{Co}=$ Cobalt
$\mathrm{Eu}=$ Europium
$K=$ Potassium

$\mathrm{Nb}=$ Niobium
$\mathrm{Pa}=$ Proactinium
$\mathrm{Pb}=$ Lead

Th = Thorium

\section{UNCONTROLLED When Printed}




\section{A.2.2.3 Contaminant Characteristics}

Contaminant characteristics include, but are not limited to, solubility, density, and adsorption potential. In general, contaminants with low solubility, high affinity for media, and high density can be expected to be found relatively close to release points. Contaminants with small particle size, high solubility, low density, and/or low affinity for media are found farther from release points or in low areas where evaporation of ponding will concentrate dissolved contaminants. Radionuclides with a low melting point (e.g., iodine) traveled significant distances before condensing and falling out of the plume, while those with higher melting points (e.g., cesium) condensed earlier and were deposited closer to respective GZs. Generally, nuclear fuel radionuclides that did not fission (e.g., U-235) have a very high melting point and are generally found very near GZ.

Residual radionuclide contaminants from nuclear weapons testing (after decay of the relatively short-lived radionuclides) are moderately to highly adsorbed on soil. An example of the inherent vertical migration potential of these contaminants through the vadose zone due to their adsorption properties is presented in Table A.2-5. This table presents estimated ranges of contaminant sorption coefficients $\left(\mathrm{K}_{\mathrm{d}}\right)$ for major radionuclide contaminants within a Yucca Flat alluvium matrix (SNJV, 2007). From these $\mathrm{K}_{\mathrm{d}}$ values, equivalent retardation factors were calculated based on an average bulk density of 1.5 grams per cubic centimeter (Hevesi et. al., 2003) and an estimated average volumetric water content of 0.18 (based on van Genuchten model parameters in SNJV, 2007). Based on these properties and a maximum estimated recharge rate of 5 millimeters per year (Hevesi et. al., 2003), the major radionuclide contaminants at CAU 571 are estimated to migrate less than $2 \mathrm{~m}$ in 1,000 years except for uranium, which could migrate up to $12.5 \mathrm{~m}$ in 1,000 years.

An example of the migration potential of radionuclides released from a nuclear detonation was demonstrated in a long-term radionuclide migration study of an underground nuclear test. A well installed into the groundwater $91 \mathrm{~m}$ away from the Cambric test GZ (and much closer to the nearest extent of the test cavity) was continuously pumped from 1975 to 1991 in order to draw radionuclides from the detonation cavity. The May 1965 Cambric test released a yield of 750 tons at a depth of $294 \mathrm{~m}$ below the land surface and $73 \mathrm{~m}$ below the water table (DOE/NV, 2000; Hoffman and Daniels, 1984). No radionuclides associated with nuclear fission tests (including the major contributing radionuclides plutonium, uranium, cesium, europium, strontium, or cobalt) other than tritium and krypton (which are considered to be conservative tracers in 
Table A.2-5

\section{Vertical Migration Potential through the Vadose Zone of the Major Radionuclide Contaminants}

\begin{tabular}{|c|c|c|c|}
\hline COC & $\begin{array}{c}\text { Approximate Range of } \\
\mathbf{K}_{\mathbf{d}} \text { Values }(\mathbf{m L} / \mathbf{g})\end{array}$ & $\begin{array}{c}\text { Equivalent } \\
\text { Retardation Factor }\end{array}$ & $\begin{array}{c}\text { Migration Distance in } \\
\mathbf{1 , 0 0 0} \text { years (m) }\end{array}$ \\
\hline \hline Uranium & $1-10$ & $4-15$ & 12.5 \\
\hline Plutonium & $100-10,000$ & $29-842$ & 1.7 \\
\hline Europium & $1,000-100,000$ & $6,840-27,228$ & $>0.1$ \\
\hline Thorium & $100-10,000$ & $544-4,733$ & $>0.1$ \\
\hline Cesium & $1,000-10,000$ & $22,132-133,355$ & $>0.1$ \\
\hline Americium & $10,000-100,000$ & $24,833-98,858$ & $>0.1$ \\
\hline
\end{tabular}

$\mathrm{mL} / \mathrm{g}=$ Milliliters per gram

groundwater, as they do not interact with the geologic media through which the water moves) were detected in the pumped groundwater during the 16 years of pumping (Bryant, 1992; Hoffman and Daniels, 1984). This test demonstrated the relative immobility of the fission radionuclides under conditions of very high mass flow (more than 1.5 billion gallons of water pumped) in a saturated matrix. Under unsaturated conditions (such as surface soil with atmospheric deposition from nuclear test releases), infiltrating water percolating through the vadose zone provides a small fraction of the migration potential (mass flow is less than $3 \mathrm{~cm}$ of recharge per year). Therefore, it can be assumed that while the major fission radionuclides are relatively immobile in saturated conditions with an artificial gradient (i.e., under pumping conditions), they will be even less mobile under unsaturated conditions with limited net infiltration of precipitation.

Based on this evidence, the major radionuclide potential contaminant (plutonium) is classified as an adsorbing radionuclide with low solubility that is located within unsaturated media. Therefore, this contaminant is expected to be found relatively close to release points.

\section{A.2.2.4 Site Characteristics}

Site characteristics are defined by the interaction of physical, topographical, and meteorological attributes and properties. Topographical and meteorological properties and attributes include slope stability, precipitation runoff pathways, and drainage channels and ephemeral drainages. Meteorological data are presented in Section 2.1. 
The CAU 571 CASs are located in Area 9 of the NNSS in Yucca Flat. The area is relatively flat with little slope. The area is sparsely vegetated with native plants. The soil at CAU 571 is made up of sand to gravel-sized alluvium of various lithologies and includes areas of disturbed soil resulting from scraping, excavation, and reworking. No perennial streamflow exists in this region. Many of the ephemeral streams in the area flow into existing craters.

\section{A.2.2.5 Migration Pathways and Transport Mechanisms}

Migration pathways include the lateral migration of potential contaminants across surface soils/sediments and vertical migration of potential contaminants through subsurface soils. Contaminants present in ephemeral washes are subject to much higher transport rates than contaminants present in other surface areas. These ephemeral washes are generally dry but are subject to infrequent stormwater flows. These stormwater flow events provide an intermittent mechanism for both vertical and lateral transport of contaminants. Contaminated sediments entrained by these stormwater events would be carried by the drainage channel flow to locations where the flowing water loses energy and the sediments drop out. These locations are readily identifiable as sedimentation areas.

Other migration pathways for contamination from the sites include windborne material and materials displaced from maintenance activities (e.g., moved during road maintenance). Contaminants may also be moved through mechanical disturbance due to maintenance or construction activities at the site. Specifically, this can include activities such as decontamination and demolition of facilities, investigation and resolution of CASs, and disassembly and removal of equipment and support structures.

Migration is influenced by the chemical characteristics of the contaminants (presented in Section A.2.2.3) and the physical characteristics of the vadose zone material (presented in Section A.2.2.4). In general, the contaminants that are reasonably expected to be present at CAU 571 (i.e., plutonium) have low solubilities and high affinity for media. The physical characteristics of the vadose zone material generally include medium and high adsorbive capacities, low moisture contents (i.e., available water-holding capacity), and relatively long distances to groundwater (e.g., 1,725 ft bgs [USGS, 2013]). Based on these physical and chemical factors, contamination is expected to be found relatively close to release points. 
Infiltration and percolation of precipitation serve as a driving force for downward migration of contaminants. However, due to high PET (61.81 in.) and limited precipitation for this region (6.35 in. per year), percolation of infiltrated precipitation at the NNSS does not provide a significant mechanism for vertical migration of contaminants to groundwater (Soule’, 2006; DOE/NV, 1992).

Underground test craters have associated chimneys of disturbed geologic material that may provide a preferential pathway. Collection of stormwater into these craters also provides additional localized infiltration that will enhance contaminant migration rates.

Subsurface migration pathways at CAU 571 are expected to be predominately vertical, although spills or leaks at the ground surface may also have limited lateral migration before infiltration. The depth of infiltration (shape of the subsurface contaminant plume) will be dependent upon the type, volume, and duration of the discharge as well as the presence of relatively impermeable layers that could modify vertical or lateral transport pathways, both on the ground surface (e.g., concrete) and in the subsurface (e.g., caliche layers).

\section{A.2.2.6 Exposure Scenarios}

Human receptors may be exposed to COPCs through oral ingestion or inhalation of, or dermal contact (absorption) with soil or debris due to inadvertent disturbance of these materials, or external irradiation by radioactive materials. The land-use and exposure scenario for the CAU 571 CASs is listed in Table A.2-6. This is based on current and future land use at the NNSS (DOE/NV, 1996). All of the CASs are at remote locations without any site improvements and where no regular work is performed. There is still the possibility, however, that site workers could occupy these locations on an occasional and temporary basis, such as a military exercise. Therefore, the current site usage is conservatively represented by the Occasional Use Area exposure scenario. 
Table A.2-6

Land-Use and Exposure Scenarios

\begin{tabular}{|c|c|c|}
\hline CAS & Record of Decision Land-Use Zone & Exposure Scenario \\
\hline \multirow{3}{*}{$\begin{array}{l}09-23-03 \\
09-23-04 \\
09-23-12 \\
09-23-13 \\
09-45-01\end{array}$} & \multirow{3}{*}{$\begin{array}{l}\text { Nuclear Test } \\
\text { This area is reserved for dynamic experiments, } \\
\text { hydrodynamic tests, and underground nuclear } \\
\text { weapons and weapons effects tests. This zone } \\
\text { includes compatible defense and nondefense } \\
\text { research, development, and testing activities. }\end{array}$} & $\begin{array}{l}\text { Industrial Area } \\
\text { Worker will be exposed to the site full time } \\
\text { (up to } 2,000 \text { hours per year for } 25 \text { years). } \\
\text { Active powered buildings with toilets are present } \\
\text { at the site. }\end{array}$ \\
\hline & & $\begin{array}{l}\text { Remote Work Area } \\
\text { Worker will be exposed to the site part time } \\
\text { (up to } 336 \text { hours per year for } 25 \text { years). Site } \\
\text { structures are present for shelter and comfort of } \\
\text { the worker. }\end{array}$ \\
\hline & & $\begin{array}{l}\text { Occasional Use Area } \\
\text { Worker will be exposed to the site occasionally } \\
\text { (up to } 80 \text { hours per year for } 5 \text { years). Site } \\
\text { structures are not present for shelter and comfort } \\
\text { of the worker. }\end{array}$ \\
\hline
\end{tabular}




\section{A.3.0 Step 2 - Identify the Goal of the Study}

Step 2 of the DQO process states how environmental data will be used in meeting objectives and solving the problem, identifies study questions or decision statement(s), and considers alternative outcomes or actions that can occur upon answering the question(s).

\section{A.3.1 Decision Statements}

- Decision I. "Is any COC associated with a CAU 571 release present in environmental media?” Any contaminant that is present (or is assumed to be present) at concentrations exceeding its corresponding FAL will be defined as a COC. A COC may also be defined as a contaminant that, in combination with other like contaminants, is determined to jointly pose an unacceptable risk based on a multiple constituent analysis (NNSA/NSO, 2012b).

- Decision II. "Is sufficient information available to evaluate potential CAAs?” Sufficient information is defined to include the following:

- The lateral and vertical extent of COC contamination

- The information needed to predict potential remediation waste types and volumes

- Any other information needed to evaluate the feasibility of remediation alternatives

For radiological contaminants, the presence of contamination at levels exceeding the FAL is defined as the condition where the most exposed worker has the potential to receive a TED of at least $25 \mathrm{mrem} / \mathrm{yr}$. The DQO process resulted in an assumption that corrective action is required within the areas exhibiting HCA conditions (Juno landfill, central windrows, small HCA); the Vesta landfill; the Mazama CA; and the URMA pile. Therefore, a default contamination boundary was established that bounds each of these areas (Section 3.4). Figure 4-1 shows the default contamination boundaries. Decision I for the default contamination boundaries is resolved, and a corrective action is necessary. Decision I will still need to be resolved for the area outside the default contamination boundaries.

For all study groups, Decision I samples will be submitted to analytical laboratories to determine the presence of a COC. Decision II samples will not be submitted for Study Group 2 because the presence of a COC will result in a corrective action being required for the entire area within the study group boundary. Decision II samples for Study Groups 1, 3, 4 and 5 will be submitted, if needed, to define the extent of a COC. In addition, samples will be submitted for analyses, as needed, to support waste management or health and safety decisions. 
A corrective action will also be required if a combination of contaminants is determined to jointly pose an unacceptable risk if PSM is identified as described in the Soils RBCA document (NNSA/NSO, 2012b).

If sufficient information is not available to evaluate potential CAAs, then site conditions will be reevaluated and additional samples will be collected (as long as the scope of the investigation is not exceeded and any CSM assumption has not been shown to be incorrect).

\section{A.3.2 Alternative Actions to the Decisions}

This section identifies actions that may be taken to solve the problem depending on the possible outcomes of the investigation.

\section{A.3.2.1 Alternative Actions to Decision I}

If no COC associated with a release is detected, further assessment of the study group is not required. If a COC associated with a release is detected in Study Group 2, the extent of contamination will be assumed to be entire area within the study group boundary. If a COC associated with a release is detected in Study Groups 1, 3, 4, and 5, the extent of COC contamination will be determined according to criteria established in Section A.4.1 and additional information required to evaluate potential CAAs will be collected.

\section{A.3.2.2 Alternative Actions to Decision II}

If the lateral and vertical extent of COC contamination have not been defined for radiological contamination, then additional samples will be collected until an $\mathrm{r}^{2}$ greater than 0.8 can be established between TED values and radiation survey values. If a valid correlation cannot be established using this criterion, the lateral and vertical extent of COC contamination will be defined by bounding locations where the TED is les than the FAL.

If the lateral and vertical extent of COC contamination have not been defined for chemical COCs, then additional bounding samples will be collected. If sample analytical results are not sufficient to predict potential remediation waste types, then additional waste characterization samples will be collected. If available information is not sufficient to evaluate the potential for migration of COC 
contamination beyond the corrective action boundary, then additional information will be collected. If sufficient information is not available to evaluate potential CAAs, then additional samples will be collected. Otherwise, collection of additional information is not required. 


\section{A.4.0 Step 3 - Identify Information Inputs}

Step 3 of the DQO process identifies the information needed, determines sources for information, and identifies sampling and analysis methods that will allow reliable comparisons with FALs.

\section{A.4.1 Information Needs}

Decision I has been resolved for the areas inside the default contamination boundaries as these areas have already been identified as requiring corrective action. Therefore, Decision I only applies to those areas outside the default contamination boundaries. To resolve Decision I (determine whether contamination from the release is present at levels exceeding a FAL) for the areas outside the default contamination boundaries, samples will be collected and analyzed following these two criteria:

- Samples must be collected in areas most likely to contain a COC (judgmental sampling) or properly represent contamination in sample plots (probabilistic sampling).

- $\quad$ The analytical suite selected must be sufficient to identify any COC present in the samples.

The extent of COC contamination portion of Decision II will be resolved using one of the following methods:

- Method 1. TED rates need to be established at locations where the TED values bound the FAL dose rate and provide sufficient information to establish an $\mathrm{r}^{2}$ greater than 0.8 between TED values and radiation survey values. A boundary will then be determined around the radiation survey isopleth the correlates to the 25-mrem/yr FAL.

- Method 2. The lateral and vertical extent of COC contamination will be defined by sample results from locations contiguous to the contamination where TED or COC concentrations are less than the FAL.

- Method 3. The lateral and vertical extent of COC contamination will be defined by the entire lateral and vertical extent of a material with clearly identifiable physical properties that is assumed to be entirely contaminated at levels exceeding the FAL. 
If additional information is needed to evaluate corrective action alternatives, samples will be collected and analyzed to meet the following criteria:

- Samples of the waste or environmental media must provide sufficient information to determine potential remediation waste types.

- Samples of the waste must provide sufficient information to determine whether the waste is PSM.

\section{A.4.2 Sources of Information}

Information to satisfy Decision I and Decision II will be generated by collecting environmental samples. These samples will be submitted to analytical laboratories meeting the quality criteria stipulated in the Soils QAP (NNSA/NSO, 2012a). TLDs will be submitted to the Environmental Technical Services group at the NNSS, which is certified by the DOE Laboratory Accreditation Program for dosimetry. Only validated data from analytical laboratories will be used to make DQO decisions. Sample collection and handling activities will follow standard procedures.

\section{A.4.2.1 Sample Locations}

Design of the sampling approaches for the CAU 571 study groups must ensure that the data collected are sufficient for selection of the CAAs (EPA, 2002). To meet this objective, the samples collected should be from locations that most likely contain a COC, if present. These sample locations, therefore, will be selected by means of biasing factors used in judgmental sampling (e.g., terrestrial radiological survey, debris). The implementation of a judgmental approach for sample location selection for CAU 571 is discussed in Section A.8.0.

\section{A.4.2.2 Analytical Methods}

Analytical methods are available to provide the data needed to resolve the decision statements. The analytical methods and laboratory requirements (e.g., precision, and accuracy) for soil samples are provided in the Soils QAP (NNSA/NSO, 2012a). 


\section{A.5.0 Step 4 - Define the Boundaries of the Study}

Step 4 of the DQO process defines the target population of interest and its relevant spatial boundaries, specifies temporal and other practical constraints associated with sample/data collection, and defines the sampling units on which decisions or estimates will be made.

\section{A.5.1 Target Populations of Interest}

The population of interest to resolve Decision I (determine whether a COC from the release is present) is contaminant concentrations exceeding a FAL at any location or area within the study group. The populations of interest to resolve Decision II (if corrective action is required, is sufficient information available to evaluate potential CAAs?) are as follows:

- For radiological contamination, TED and corresponding radiation survey values from locations where TED varies from above the FAL to below the FAL

- For chemical contamination, COC concentrations for each one of a set of locations bounding contamination in lateral and vertical directions

- IDW and potential remediation waste characteristics

\section{A.5.2 Spatial Boundaries}

Spatial boundaries are the maximum lateral and vertical extent of expected contamination that can be supported by the CSM. These boundaries were agreed to in the DQO meeting with decision makers. Decision II spatial boundaries are as follows:

- Vertical: 2 in. below original ground surface for Study Group 1, and 25 ft for Study Groups 2 through 5

- Lateral: $1 \mathrm{mi}$ from the boundaries of all the study groups

Contamination found beyond these boundaries may indicate a flaw in the CSM and may require reevaluation of the CSM before the investigation can continue. Each study group is considered geographically independent, and intrusive activities are not intended to extend into the boundaries of neighboring study groups. 


\section{A.5.3 Practical Constraints}

Practical constraints (e.g., activities by other organizations at the NNSS, utilities, threatened or endangered animals and plants, unstable or steep terrain, and/or access restrictions) may affect the ability to investigate this site. Practical constraints that have been identified specific to CAU 571 include the presence of multiple subsidence craters from underground testing that was conducted in the areas surrounding the atmospheric testing GZs.

\section{A.5.4 Define the Sampling Units}

The scale of decision making refers to the smallest, most appropriate area or volume for which decisions will be made. The scale of decision making in Decision I is the CAS component (defined by a specific release). The presence of a COC associated with a CAS component will cause the determination that the CAS component is contaminated and needs further evaluation. The Decision I scale of decision making for Study Groups 1, 2, and 5 is the entire release. The Decision I scale of decision making for Study Group 3 is each windrow zone. The Decision I scale of decision making for Study Group 4 is each sedimentation area.

The scale of decision making for Decision II for all study groups is defined as a contiguous area containing a COC originating from the CAS component. Resolution of Decision II requires this contiguous area to be bounded laterally and vertically. 


\section{A.6.0 Step 5 - Develop the Analytic Approach}

Step 5 of the DQO process specifies appropriate population parameters for making decisions, defines action levels, and generates a decision rule.

\section{A.6.1 Population Parameters}

Population parameters are defined for judgmental and probablistic sampling designs in the following subsections. Population parameters are the parameters compared to action levels.

\section{A.6.1.1 Judgmental Sampling Design}

The judgmental design will be implemented as described in the Soils RBCA document (NNSA/NSO, 2012b). For chemical contaminants, the population parameter is the observed concentration of each contaminant from each individual analytical sample. For radiological contaminants, the population parameter is the calculated TED from each location. Each sample result will be compared to the FALs to determine the appropriate resolution to Decision I and Decision II. A single sample result for any contaminant exceeding a FAL would cause a determination that a corrective action is required (for Decision I), or that the extent of COC contamination is not bounded (for Decision II).

\section{A.6.1.2 Probabilistic Sampling Design}

For probabilistic sampling results, the population parameter is the true TED over the area of the sample plot. Resolution of DQO decisions associated with the probabilistic sampling design requires determining, with a specified degree of confidence, whether the true TED at the site in question exceeds the FAL. Because a calculated TED is an estimate of the true (unknown) TED, it is uncertain how well the calculated TED represents the true TED. If the calculated TED were significantly different than the true TED, a decision based on the calculated TED could result in a decision error. To reduce the probability of making a false negative decision error, a conservative estimate of the true TED is used to compare to the FAL instead of the calculated TED. This conservative estimate (overestimation) of the true TED was calculated as the 95 percent UCL of the average TED measurements (Section 4.1). By definition, there is a 95 percent probability that the true TED is less than the 95 percent UCL of the calculated TED. 
The computation of appropriate UCLs will be accomplished as described in the Soils RBCA document (NNSA/NSO, 2012b).

\section{A.6.2 Action Levels}

The PALs presented in this section are to be used for site screening purposes. They are not necessarily intended to be used as cleanup action levels or FALs. However, they are useful in screening out contaminants that are not present in sufficient concentrations to warrant further evaluation and, therefore, streamline the consideration of remedial alternatives. The RBCA process used to establish FALs is described in the Soils RBCA document (NNSA/NSO, 2012b). This process conforms with NAC 445A.227, which lists the requirements for sites with soil contamination (NAC, 2012a). For the evaluation of corrective actions, NAC 445A.22705 (NAC, 2012b) requires the use of ASTM Method E1739 (ASTM, 1995) to “conduct an evaluation of the site, based on the risk it poses to public health and the environment, to determine the necessary remediation standards or to establish that corrective action is not necessary.” For the evaluation of corrective actions, the FALs are established as the necessary remedial standard.

This RBCA process defines three tiers (or levels) of evaluation involving increasingly sophisticated analyses.

The comparison of laboratory results to FALs and the evaluation of potential corrective actions will be included in the investigation report. The FALs will be defined (along with the basis for their definition) in the investigation report.

\section{A.6.2.1 Chemical PALs}

Except as noted herein, the chemical PALs are defined as the Region 9 Regional Screening Levels for chemical contaminants in industrial soils (EPA, 2013a). Background concentrations for RCRA metals will be used instead of screening levels when natural background concentrations exceed the screening level (e.g., arsenic on the NNSS). Background is considered the average concentration plus two standard deviations of the average concentration for sediment samples collected by the Nevada Bureau of Mines and Geology throughout the Nevada Test and Training Range (formerly the Nellis Air Force Range) (NBMG, 1998; Moore, 1999). For detected chemical COPCs without established 
screening levels, the protocol used by EPA Region 9 in establishing screening levels (or similar) will be used to establish PALs. If used, this process will be documented in the investigation report.

\section{A.6.2.2 Radionuclide PALs}

The PAL for radioactive contaminants is a TED of $25 \mathrm{mrem} / \mathrm{yr}$, based upon the Industrial Area exposure scenario. The Industrial Area exposure scenario is described in the Soils RBCA document (NNSA/NSO, 2012b).

\section{A.6.3 Decision Rules}

The decision rules applicable to both Decision I and Decision II are as follows:

- If contamination levels are inconsistent with the CSM or extend beyond the spatial boundaries identified in Section A.5.2, then work will be suspended and the investigation strategy will be reconsidered, else the decision will be to continue sampling.

The decision rules for Decision I are as follows:

- If the population parameter of any COPC in the Decision I population of interest (defined in Step 4) exceeds the corresponding FAL, then Decision II will be resolved and a corrective action will be determined, else no further action is needed for that COPC in that population.

- If a waste is present that, if released, has the potential to cause the future contamination of site environmental media, then a corrective action will be determined, else no further action will be necessary.

The decision rules for Decision II are as follows:

- If the spatial extent of any COC has not been defined, then additional samples will be collected, else no further investigation will be necessary.

- If sufficient information is not available to determine potential remediation waste types and evaluate the feasibility of remediation alternatives, additional waste characterization samples will be collected, else no further investigation will be necessary. 


\section{A.7.0 Step 6 - Specify Performance or Acceptance Criteria}

Step 6 of the DQO process defines the decision hypotheses, specifies controls against false rejection and false acceptance decision errors, examines consequences of making incorrect decisions from the test, and places acceptable limits on the likelihood of making decision errors.

\section{A.7.1 Decision Hypotheses}

The baseline condition (i.e., null hypothesis) and alternative condition for Decision I are as follows:

- Baseline condition. A COC is present.

- Alternative condition. A COC is not present.

The baseline condition (i.e., null hypothesis) and alternative condition for Decision II are as follows:

- Baseline condition. The extent of a COC has not been defined.

- Alternative condition. The extent of a COC has been defined.

Decisions and/or criteria have false negative or false positive errors associated with their determination. The impact of these decision errors and the methods that will be used to control these errors are discussed in the following subsections. In general terms, confidence in DQO decisions based on judgmental sampling results will be established qualitatively by the following:

- Developing a CSM (based on process knowledge) that is agreed to by decision-making participants during the DQO process.

- $\quad$ Testing the validity of the CSM based on investigation results.

- Evaluating the quality of data based on DQI parameters.

\section{A.7.2 False Negative Decision Error}

The false negative decision error would mean deciding that a COC is not present when it actually is (Decision I), or deciding that the extent of a COC has been defined when it has not (Decision II). In both cases, the potential consequence is an increased risk to human health and environment. 


\section{A.7.2.1 False Negative Decision Error for Judgmental Sampling}

In judgmental sampling, the selection of the number and location of samples is based on knowledge of the feature or condition under investigation and on professional judgment (EPA, 2002). Judgmental sampling conclusions about the target population depend upon the validity and accuracy of professional judgment.

The false negative decision error (where consequences are more severe) for judgmental sampling designs is controlled by meeting these criteria:

- For Decision I, having a high degree of confidence that the sample locations selected will identify a COC if present anywhere within the study group. For Decision II, having a high degree of confidence that the sample locations selected will identify the extent of a COC.

- Having a high degree of confidence that analyses conducted will be sufficient to detect any COC present in the samples.

- Having a high degree of confidence that the dataset is of sufficient quality and completeness.

To satisfy the first criterion, Decision I samples must be collected in areas most likely to be contaminated by a COC (supplemented by unbiased samples where appropriate). Decision II samples must be collected in areas that represent the lateral and vertical extent of contamination (above FALs). The following characteristics must be considered to control decision errors for the first criterion:

- Source and location of release

- Chemical nature and fate properties

- Physical transport pathways and properties

- Hydrologic drivers

These characteristics were considered during the development of the CSM and selection of sampling locations. Field-screening methods and biasing factors will be used to further ensure that appropriate sampling locations are selected to meet these criteria. The investigation report will present an assessment on the DQI of representativeness that samples were collected from those locations that best represent the populations of interest as defined in Section A.5.1. 
To satisfy the second criterion, Decision I soil samples will be analyzed for the chemical and radiological parameters listed in Section 3.2. Decision II soil samples will be analyzed for unbounded COCs. The DQI of sensitivity will be assessed for all analytical results to ensure that all sample analyses had measurement sensitivities (detection limits) that were less than or equal to the corresponding FALs. If this criterion is not achieved, the affected data will be assessed (for usability and potential impacts on meeting site characterization objectives) in the investigation report.

To satisfy the third criterion, the entire dataset of soil sample results, as well as individual soil sample results, will be assessed against the DQIs of precision, accuracy, comparability, and completeness as defined in the Soils QAP (NNSA/NSO, 2012a). The DQIs of precision and accuracy will be used to assess overall analytical method performance as well as to assess the need to potentially "flag" (qualify) individual contaminant results when corresponding QC sample results are not within the established control limits for precision and accuracy. Data qualified as estimated for reasons of precision or accuracy may be considered to meet the analyte performance criteria based on an assessment of the data. The DQI for completeness will be assessed to ensure that all data needs identified in the DQO have been met. The DQI of comparability will be assessed to ensure that all analytical methods used are equivalent to standard EPA methods so that results will be comparable to regulatory action levels that have been established using those procedures. Strict adherence to established procedures and QA/QC protocol protects against false negatives.

To provide information for the assessment of the DQIs of precision and accuracy, laboratory QC samples will be selected and analyzed in every batch of up to 20 samples per matrix.

\section{A.7.2.2 False Negative Decision Error for Probabilistic Sampling}

The false negative decision error rate goal was established by the DQO meeting participants at 5 percent. Upon validation of the analytical results, statistical parameters will be calculated for each significant COPC identified at each site. Protection against a false negative decision error is contingent upon the following:

- Sample size

- Actual variability

- Measurement error 
Control of the false negative decision error for probabilistic sampling designs is accomplished by ensuring that the following requirements are met for each of the significant COPCs:

- A sufficient sample size was collected.

- The actual standard deviation is calculated.

- Analyses conducted were sufficient to detect contamination exceeding FALs.

\section{A.7.3 False Positive Decision Error}

The false positive decision error would mean deciding that a COC is present when it is not, or a COC is unbounded when it is not, resulting in increased costs for unnecessary sampling and analysis.

False positive results are typically attributed to laboratory and/or sampling/handling errors that could cause cross contamination. To control against cross contamination, decontamination of sampling equipment will be conducted in accordance with established and approved procedures, and only clean sample containers will be used. To determine whether a false positive analytical result may have occurred, the following QC samples will be collected per the Soils QAP:

- Trip blanks (1 per sample cooler containing VOC environmental samples)

- Equipment rinsate blanks (1 per wet decontamination event, if used)

- Source blanks (1 per uncharacterized source lot per lot)

- Field blank (1 per sampling event, if site conditions suggest probability that cross-contamination may occur)

For probabilistic sampling, false positive decision error rate goal was established by the DQO meeting participants at 0.20 (or 20 percent probability). Protection against this decision error is also afforded by the controls listed in Section A.7.2 for probabilistic sampling designs. 


\section{A.8.0 Step 7 - Develop the Plan for Obtaining Data}

Step 7 of the DQO process selects and documents a design that will produce data that exceeds performance or acceptance criteria. Judgmental sampling schemes will be implemented to select sample plot and grab sample locations. Probabilistic sampling schemes will be implemented to select the sample locations within each of the sample plots. Judgmental sampling will also be used to investigate any newly-discovered releases as described in Section A.2.2.1. Investigation results will be compared to FALs to determine the need for corrective action. PSM sample results will be evaluated against the PSM criteria listed in the Soils RBCA document (NNSA/NSO, 2012b) to determine the need for corrective action.

\section{A.8.1 Study Group 1, Atmospheric Release}

The sampling plan for this group is focused on contamination from two atmospheric weapons tests and two atmospheric safety experiments conducted in 1955 and 1958, and the contamination of surface soil resulting from these four tests.

\section{A.8.1.1 Decision I Sample Selection}

The area near the GZs of the atmospheric releases has been highly disturbed since the four tests were conducted due to the decontamination activities and underground testing that took place. Therefore, the areas that are relatively undisturbed and are suitable to sample for the atmospheric release are located outside the default contamination boundaries and the boundaries of the other study groups. One sample plot location will be selected based on the highest radiological value in each of three different areas.

Figure A.8-1 shows an example of where the three sample plots may be located. These locations may be adjusted based on comprehensive radiological walkover surveys.

\section{A.8.1.2 Decision II Sample Selection}

Preliminary investigation terrestrial radiological survey values are very near background, so no Decision II sample locations have been selected. If a COC is identified, Decision II planning will be conducted with the stakeholders. 


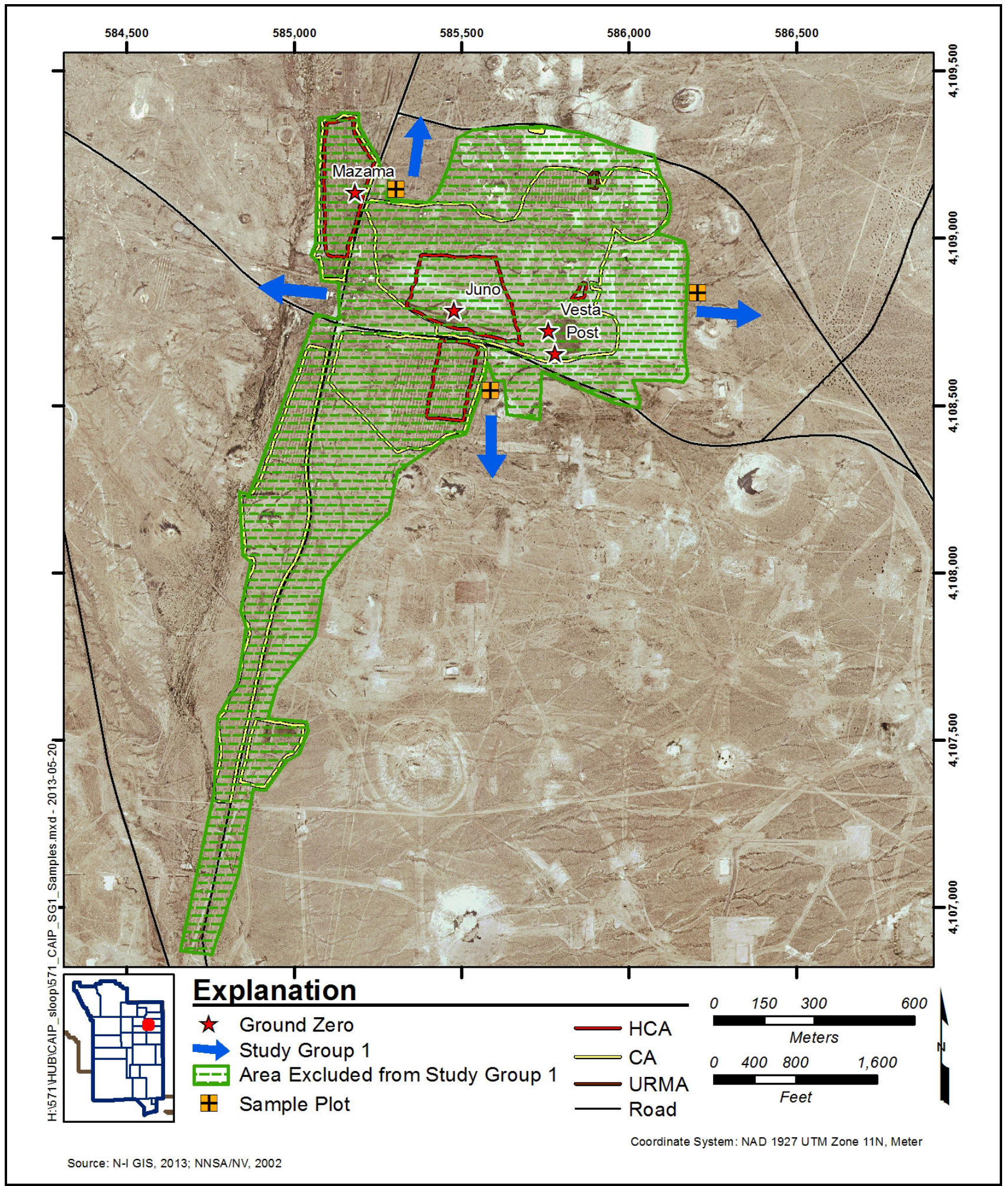

Figure A.8-1

Decision I Sample Locations for Study Group 1, Atmospheric Release 


\section{A.8.1.3 Sampling of Sample Plots}

The probabilistic sampling scheme will be implemented to select sample locations within the sample plots and evaluate the analytical results. For each of the four composite samples collected within the sample plot, nine randomly selected subsample locations will be chosen based on a random start, triangular pattern (see Figure A.8-2 for an example of this sampling scheme). If sufficient sample material cannot be collected at a specified location (e.g., due to the presence of rock, caliche, or buried concrete), the sample will be collected from the nearest location that a surface sample can be obtained. A TLD will be placed in the center of each sample plot to measure the external dose.

\section{A.8.1.4 Calculation of Dose}

Internal, external, and TED will be calculated using the appropriate exposure scenario and the methodologies described in the Soils RBCA document (NNSA/NSO, 2012b). The TED will be determined by summing internal and external dose measurements at each sample location. For probabilistic sampling of radiological contamination, DQO decisions will be based on the 95 percent UCL of the average TED.

\section{A.8.2 Study Group 2, Subsurface Contamination}

Study Group 2 consists of an area with contamination associated with the atmospheric release that was disturbed after the original deposition of radionuclides to the surface soil. Therefore, it is reasonable to suspect that contamination may be present at depths greater than $5 \mathrm{~cm}$. Sampling in this study group will take into account that contamination may be present on the surface or shallow subsurface.

\section{A.8.2.1 Decision I Sample Selection}

A judgmental sampling design will be implemented for locating Decision I sample plots for Study Group 2, outside the default contamination boundaries. Two sample plot locations will be selected judgmentally based on the highest results of the terrestrial radiological surveys. An additional 14 sample plots will be selected based on proximity to the Juno and Vesta GZs. Because it assumed that contamination will decrease with distance from the source, the sample plots will be selected adjacent to the Juno and Vesta landfill default contamination boundaries. 


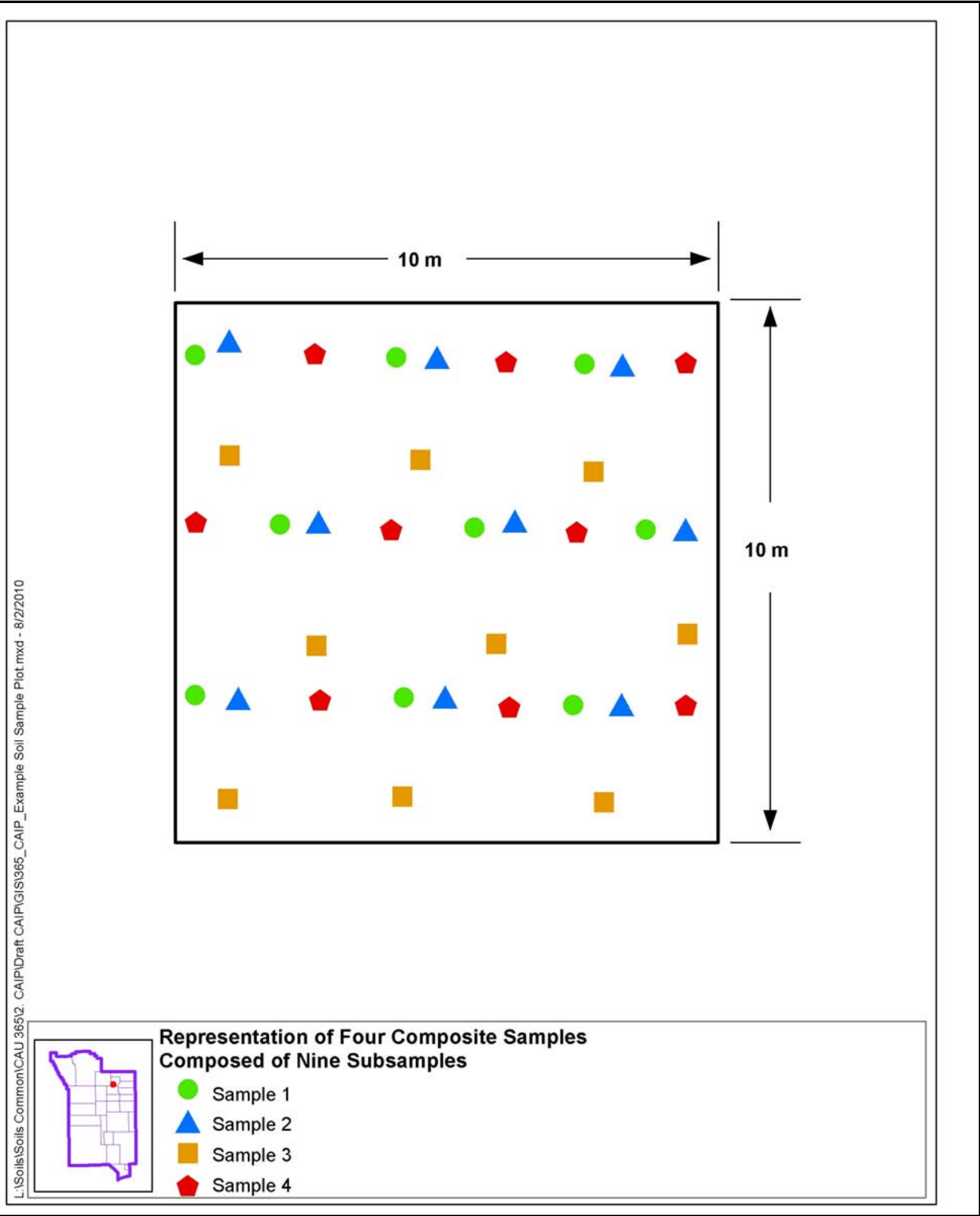

Figure A.8-2

Sample Plot Sample Collection Layout 
Figure A.8-3 shows an example of where the 16 sample plots may be located. The locations of the two sample plots based on surface radiological values may be adjusted based on comprehensive radiological walkover surveys. The other 14 sample plot locations may be adjusted as necessary if a feature impedes the sampling in that particular location.

Decision II sampling will not be required. Because the area within Study Group 2 has been extensively disturbed, if contamination over the FAL is identified, it is assumed that it may also be present elsewhere within the study group. Therefore, if a sample result at a single plot exceeds the FAL, the extent of COC contamination will be established as the study group boundary. Therefore, the entire Study Group 2 area would require corrective action.

See Sections A.8.1.3 and A.8.1.4 for an explanation of sample plot collection and how dose is calculated from the sample results.

\section{A.8.2.2 Determination of Buried Contamination}

As the CSM includes the possibility of buried contamination within Study Group 2, it will be determined whether buried contamination exists. Soil will be evaluated for subsurface contamination at the established center sample location within each of the sample plots. The subsurface soil grab samples will be evaluated in the following manner:

- A 5-cm layer of soil will be removed from the sample location.

- The surface sample will be screened with alpha/beta detection meter.

- Subsequent intervals will be screened until native soil is encountered.

Samples will be taken at 5-cm intervals until native soil is encountered. If subsurface screening results are not greater than 20 percent of the surface screening results, it will be assumed that buried contamination does not exist, and no samples will be collected and submitted for analyses. If screening results are significantly different from the surface results, it will be assumed that buried contamination exists.

If buried contamination exists, it will be conservatively assumed that the highest level of contamination observed will provide a dose to site workers. Therefore, the highest dose (surface or subsurface) at each location will be used for the dose estimate. The highest TED from either surface or subsurface samples will be used to resolve DQO decisions. If a subsurface sample results in a 


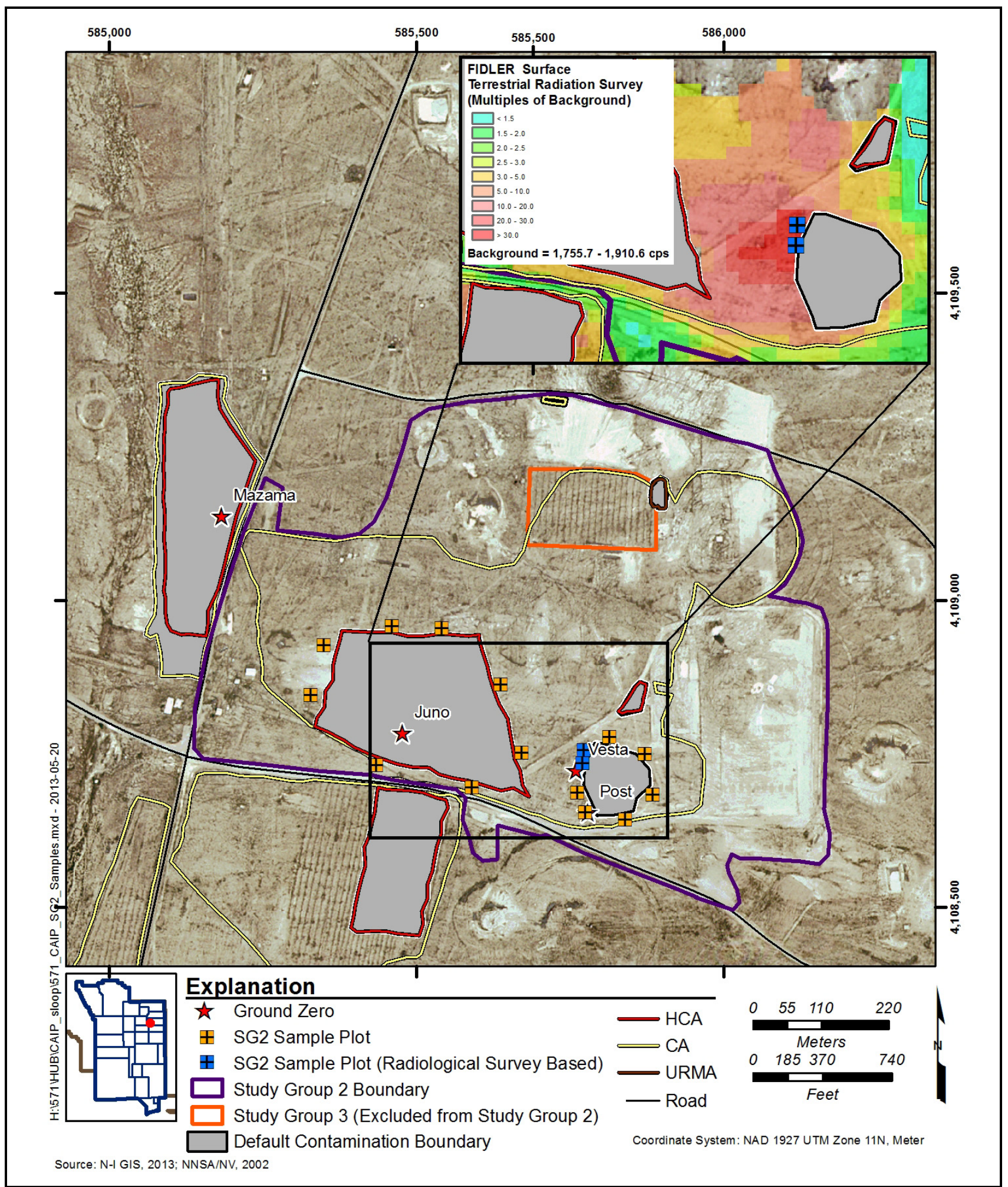

Figure A.8-3

Decision I Sample Locations for Study Group 2, Subsurface Contamination 
higher internal dose than a surface sample, a TLD-equivalent external dose will be calculated for the subsurface sample. This will be accomplished by establishing a correlation between RESRAD-calculated external dose from surface samples and the RESRAD-calculated external dose from the subsurface samples. This surface TLD reading will be increased by this proportion to estimate a TLD-equivalent external dose for the subsurface soil.

\section{A.8.3 Study Group 3, Windrows}

The radioactive contamination on surface soils that was left in situ and scraped into windrows exhibits contamination consistent with the original atmospheric release plume directions from Juno (southward) and Vesta (northward). The residual spatial distribution of radionuclides visible on both the 2012 aerial radiological surveys and recent terrestrial radiological surveys confirm that contamination generally decreases with distance from the GZs. However, although the windrows were created as a result of contamination scraped in place, there is the potential that some transfer of contamination took place during the decontamination of the access road and when the windrows were disturbed from their original configuration. Therefore, to adequately investigate the windrows, the windrows have been categorized into five zones based on proximity to the Juno and Vesta GZs, location along the access road, and radiological postings. See Table 4-1 for an explanation of the zones. The windrows were also sprayed with hot road oil, which could result in chemical contamination of the soil.

\section{A.8.3.1 Decision I Sample Selection}

A biased sampling strategy will be implemented to target areas with the highest potential to contain a COC. Therefore, a judgmental sampling design will be implemented for locating Decision I sample locations for Study Group 3, outside the default contamination boundaries. Two sample locations in each of the five zones will be selected judgmentally based on the highest results of the terrestrial radiological surveys. These sample locations may be adjusted during the investigation if an area with higher surface soil radiological values are identified. These samples will also be collected to evaluate potential chemical contamination of the soil. Samples will be collected as discussed in Section 4.2.3. Figure A.8-4 shows an example of where the sample locations may be located. 


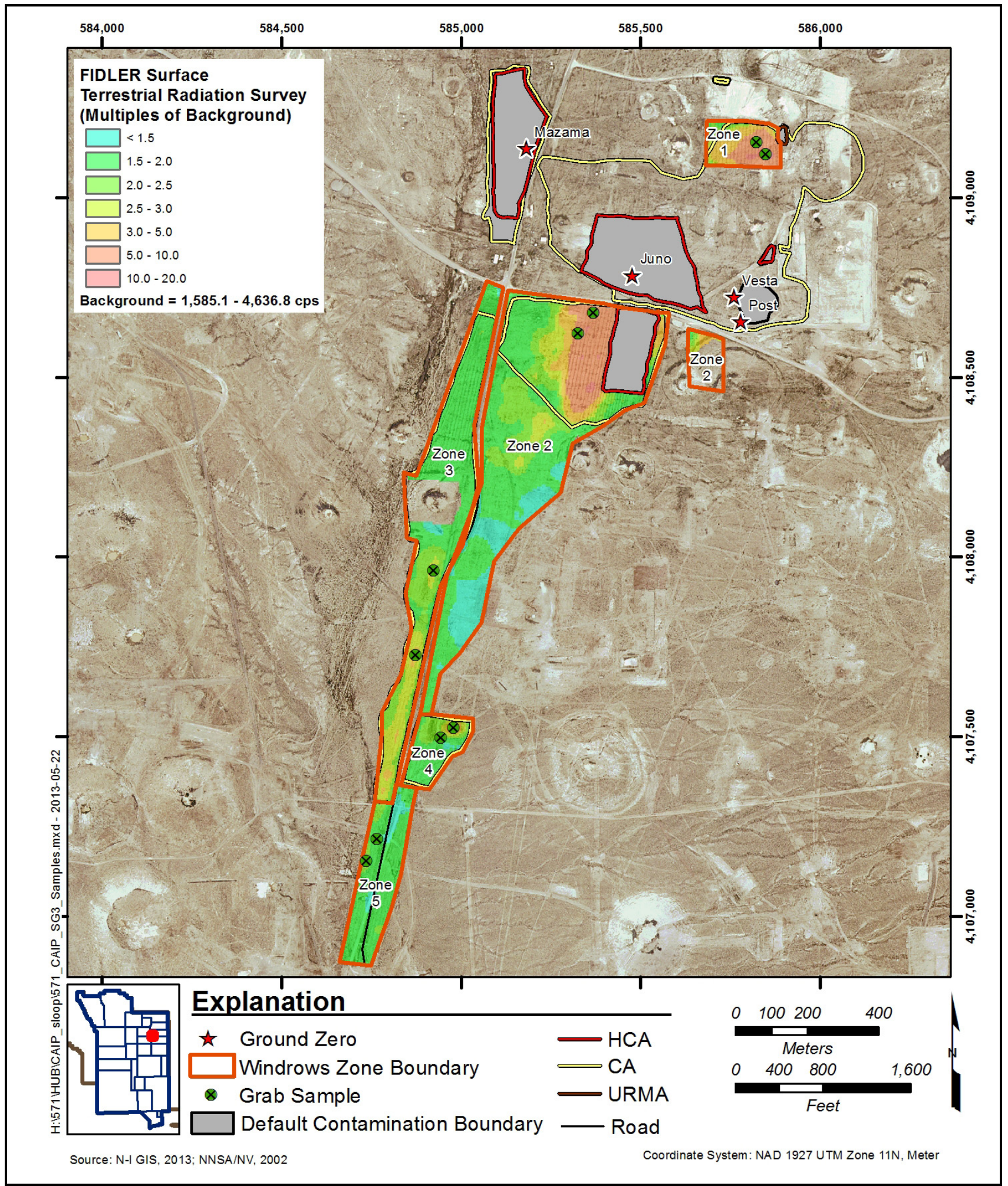

Figure A.8-4

Decision I Sample Locations for Study Group 3, Windrows 


\section{A.8.3.2 Decision II Sample Selection}

If a radiological COC is identified for any windrow zone, Decision II sampling will be required to meet the criteria listed in Section A.4.1 for defining the extent of COC contamination. Additional sample locations will be selected using the terrestrial radiological surveys. If a chemical COC is identified, the entire windrow zone will require corrective action, so no Decision II sampling will be required.

\section{A.8.4 Study Group 4, Drainage}

The migration of contamination is most likely to occur due to surface runoff in drainages from the sites. A small drainage that has formed as a result of man-made structures along the southern side of 9-01 Road will be investigated.

\section{A.8.4.1 Decision I Sample Selection}

For the investigation of drainages, sample locations will be selected from the center of sediment collection areas and/or at locations of elevated radiological readings within the sedimentation collection areas for those areas that are located outside the default contamination boundary of the central windrows HCA. Judgmental samples will be collected as follows:

- At each sample location within the sediment accumulation area, a sample will be collected from each $10-\mathrm{cm}$ depth interval until native material is encountered.

- Each sample will be field screened with an alpha/beta detection meter and compared to the established background FSL for the site.

- If the depth sample with the highest FSR is not significantly different (at least 20 percent difference) than the FSR of the surface sample, then only the surface sample will be submitted for analysis. If the FSR is greater than 20 percent higher than the surface sample, then both the surface sample and the depth sample with the elevated FSR will be submitted for analysis unless the FSL is not exceeded by any sample.

- A TLD will be placed at each sample location.

It will be conservatively assumed that the highest TED from either surface or subsurface samples will be used to resolve DQO decisions. If buried contamination exists (as defined in Section A.8.2.2), a 
TLD-equivalent external dose will be calculated for the subsurface sample. This will be accomplished by using the method described in Section A.8.2.2.

All drainage samples will be submitted for the analyses listed under Study Group 4 in Table A.2-3. Information (such as sample results and the results of the radiological survey) needed to assess the potential for future migration of the 25-mrem/yr boundary will be obtained during the field investigation and addressed in the investigation report. Additionally, if an additional drainage is identified during the investigation that has a potential to contain a COC, the drainage will be evaluated as necessary. Figure A.8-5 shows an example of where the drainage samples may be located.

\section{A.8.4.2 Decision II Sample Selection}

If a contamination level exceeding a FAL is found in drainage at a sediment accumulation area sample location, additional sedimentation areas will be sampled until at least two consecutive sedimentation areas are found that do not contain contamination levels exceeding a FAL. Decision II will be resolved by the assumption that the entire volume of sediment in each sediment accumulation area where a contamination level exceeding a FAL was identified exceeds the FAL.

\section{A.8.5 Study Group 5, Other}

Sample locations for releases identified in Study Group 5 will be determined based upon the likelihood of a contaminant release at each site. These locations will be selected based on the identification of biasing factors during the investigation. The need for additional sampling may be identified during site characterization activities (and will be investigated as appropriate) based on the following factors:

- Stains: Any spot or area on the soil surface that may indicate the presence of a potentially hazardous liquid. Typically, stains indicate an organic liquid, such as oil, has reached the soil and may have spread vertically or laterally.

- Radiological survey anomalies: Radiological survey results that are significantly higher than the surrounding area.

- Drums, containers, equipment, debris: Materials that contain or may have contained hazardous or radioactive materials. 


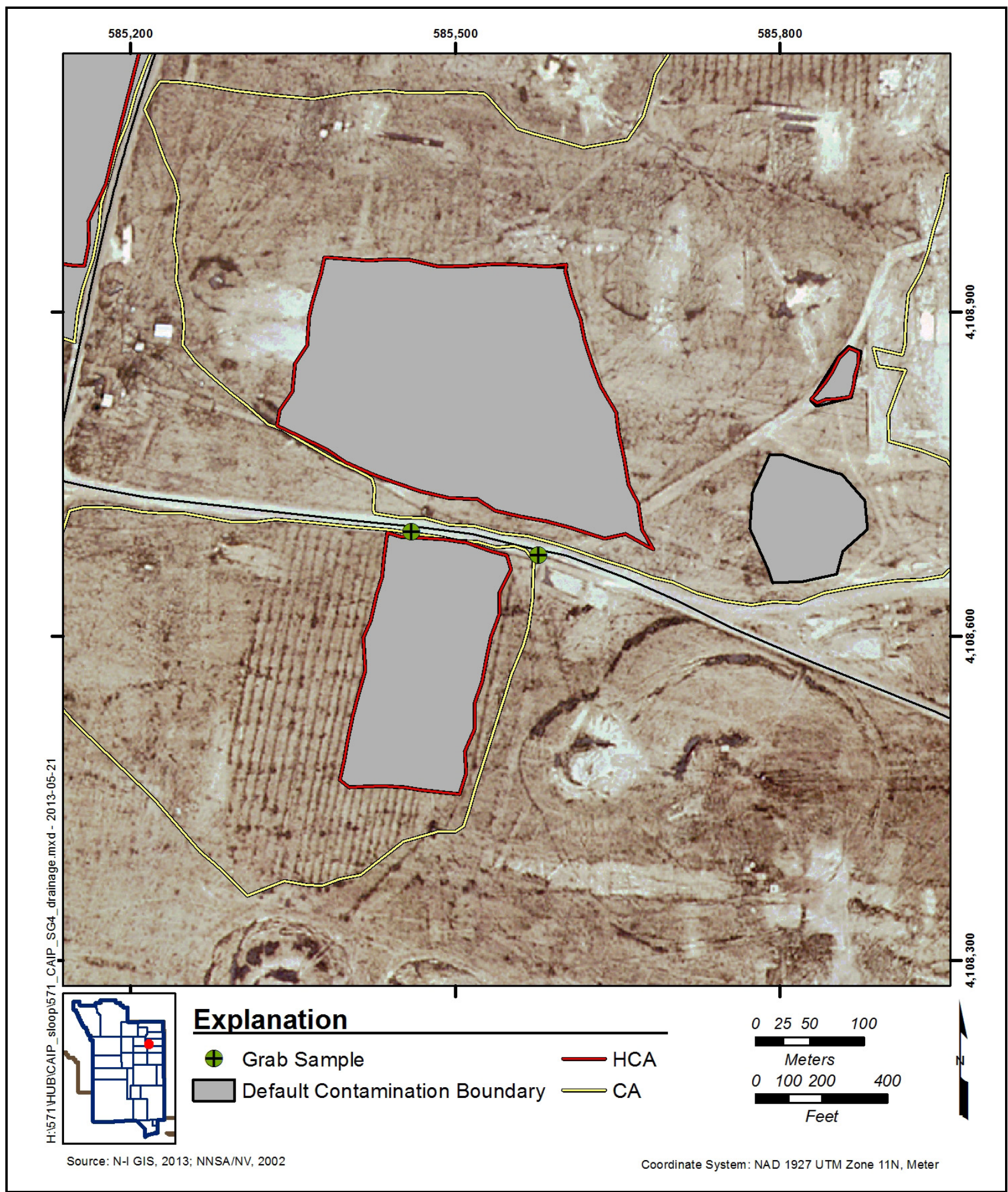

Figure A.8-5

Decision I Sample Locations for Study Group 4, Drainage 
- Lithology: Locations where variations on lithology (soil or rock) indicate that different conditions or materials exist.

- Preselected areas based on process knowledge of the site: Locations for which evidence such as historical photographs, experience from previous investigations, or historical documentation exists that a release of hazardous or radioactive substance may have been occurred.

- Preselected areas based on process knowledge of contaminants: Locations that may reasonably have received contamination, selected on the basis of the chemical and/or physical properties of the contaminant(s) in the environmental setting.

- $\quad$ Other biasing factors: Factors not previously defined for the CAI that become evident during the CAI.

\section{A.8.5.1 Decision I Sample Selection}

Currently, PSM, an asphalt pile, and a radiologically posted CA have been identified as Study Group 5 releases (Figure A.8-6). Decision I samples will be collected from the material that presents the greatest degree of the biasing factor identified (surface or subsurface). For PSM, specific analyses will be requested based on the nature of the potential release (e.g., RCRA metal analysis at a lead brick PSM location). At the asphalt pile, a sample will be collected from below the asphalt material and also at the downgradient toe of the pile. The samples will be analyzed for VOCs and SVOCs. For the northern CA, a sample plot will be selected in the area with the highest radiological value as identified on the terrestrial radiological survey. The samples will be analyzed for the radiological analyses listed in Table A.2-3.

\section{A.8.5.2 Decision II Sample Selection}

Decision II samples will be collected from locations where a COC was detected. For PSM and the asphalt pile, sample locations will be arranged in a triangular pattern around the area containing a COC at distances based on site conditions, process knowledge, and biasing factors. If a COC extends beyond the initial step-outs, Decision II samples will be collected from incremental step-outs. Initial step-outs will be at least as deep as the vertical extent of contamination defined at the Decision I location and the depth of the incremental step-outs will be based on the deepest contamination observed at any location within the release. A clean sample (i.e., contamination levels less than FALs) collected from each step-out direction (lateral or vertical) will define extent of contamination in 


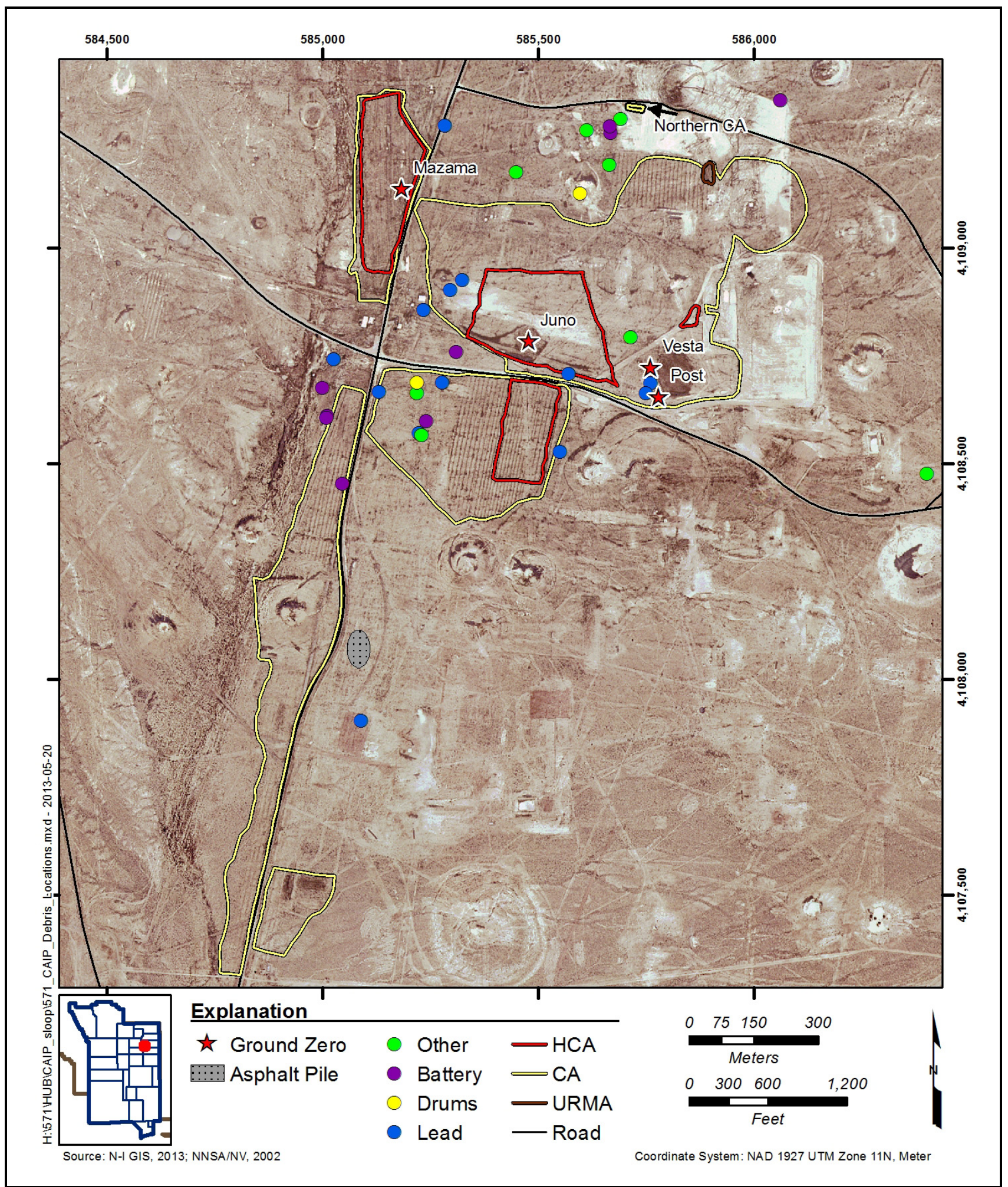

Figure A.8-6

Debris and Features for Investigation for Study Group 5, Other 
that direction. Because of the low radiological values identified in the northern CA, COCs are not expected to be present. If COCs are found, Decision II planning will be conducted with the stakeholders.

\section{A.8.6 Establishment of Final Corrective Action Boundary}

The final corrective action boundary will be established to include the default contamination boundaries, the initial corrective action boundary, any additional areas that exceed the FAL. 


\section{A.9.0 References}

ASTM, see ASTM International.

ASTM International. 1995 (reapproved 2010). Standard Guide for Risk-Based Corrective Action Applied at Petroleum Release Sites, ASTM E1739 - 95(2010)e1. West Conshohocken, PA.

Bryant, E.A. 1992. The Cambric Migration Experiment, A Summary Report, LA-12335-MS. Los Alamos, NM: Los Alamos National Laboratory.

DOE, see U.S. Department of Energy.

DOE/NV, see U.S. Department of Energy, Nevada Operations Office.

EPA, see U.S. Environmental Protection Agency.

Gilbert, R.O., E.H. Essington, D.N. Brady, P.G. Doctor, and L.L Eberhardt. 1977. "Statistical Activities during 1976 and the Design and Initial Analysis of Nuclear Site Studies.” In Transuranics in Desert Ecosystems, NVO-181. pp. 331-366. November. Las Vegas, NV: U.S. Department of Energy, Nevada Operations Office.

Hevesi, J.A., A.L. Flint, and L.E. Flint. 2003. Simulation of Net Infiltration and Potential Recharge Using a Distributed-Parameter Watershed Model of the Death Valley Region, Nevada and California, Water-Resources Investigations Report 03-4090. Sacramento, CA: U.S. Geological Survey.

Hoffman, D.C., and W.R. Daniels. 1984. "Assessment of the Potential for Radionuclide Migration from a Nuclear Explosion Cavity.” In Groundwater Contamination, pp. 139-146. Washington, DC: National Academy Press.

McArthur, R.D., and J.F. Kordas. 1983. Radionuclide Inventory and Distribution Program: The Galileo Area, DOE/NV/10162-14; Publication No. 45035. Las Vegas, NV: Desert Research Institute, Water Resources Center.

McArthur, R.D., and J.F. Kordas. 1985. Nevada Test Site Radionuclide Inventory and Distribution Program: Report \#2. Areas 2 and 4, DOE/NV/10162-20; Publication No. 45041. Las Vegas, NV: Desert Research Institute, Water Resources Center.

Moore, J., Science Applications International Corporation. 1999. Memorandum to M Todd (SAIC) titled "Background Concentrations for NTS and TTR Soil Samples,” 3 February. Las Vegas, NV: IT Corporation.

NAC, see Nevada Administrative Code. 
NBMG, see Nevada Bureau of Mines and Geology.

N-I GIS, see Navarro-Intera Geographic Information Systems.

NNSA/NSO, see U.S. Department of Energy, National Nuclear Security Administration Nevada Site Office.

NNSA/NV, see U.S. Department of Energy, National Nuclear Security Administration Nevada Operations Office.

Navarro-Intera Geographic Information Systems. 2013. ESRI ArcGIS Software.

Nevada Administrative Code. 2012a. NAC 445A.227, “Contamination of Soil: Order by Director for Corrective Action; Factors To Be Considered in Determining Whether Corrective Action Required.” Carson City, NV. As accessed at http://www.leg.state.nv.us/nac on 12 April 2013.

Nevada Administrative Code. 2012b. NAC 445A.22705, “Contamination of Soil: Evaluation of Site by Owner or Operator; Review of Evaluation by Division.” Carson City, NV. As accessed at http://www.leg.state.nv.us/nac on 12 April 2013.

Nevada Bureau of Mines and Geology. 1998. Mineral and Energy Resource Assessment of the Nellis Air Force Range, Open-File Report 98-1. Reno, NV.

SNJV, see Stoller-Navarro Joint Venture.

Soule', D.A. 2006. Climatology of the Nevada Test Site, SORD Technical Memorandum 2006-03. Silver Spring, MD: National Oceanographic and Atmospheric Administration, Air Resources Laboratory.

Stoller-Navarro Joint Venture. 2007. Phase I Contaminant Transport Parameters for the Groundwater Flow and Contaminant Transport Model of Corrective Action Unit 97: Yucca Flat/Climax Mine, Nevada Test Site, Nye County, Nevada, Rev. 0, S-N/99205--096. Las Vegas, NV.

Tamura, T. 1977. "Plutonium Distribution in a Desert Pavement.Desert Mound Soil System in Area 11.” In Environmental Plutonium on the Nevada Test Site and Environs, NVO-171. June. Las Vegas, NV: Energy Research and Development Administration, Nevada Applied Ecology Group.

USGS, see U.S. Geological Survey.

U.S. Department of Energy. 1997. The Procedures Manual of the Environmental Measurements Laboratory, HASL-300, 28th Ed., Vol. I. February. New York, NY. 
U.S. Department of Energy, National Nuclear Security Administration Nevada Operations Office. 2002. Nevada Test Site Orthophoto Site Atlas, DOE/NV/11718--604. Aerial photos acquired Summer 1998. Prepared by Bechtel Nevada. Las Vegas, NV.

U.S. Department of Energy, National Nuclear Security Administration Nevada Operations Office. 2012a. Soils Activity Quality Assurance Plan, Rev. 0, DOE/NV--1478. Las Vegas, NV.

U.S. Department of Energy, National Nuclear Security Administration Nevada Site Office. 2012b. Soils Risk-Based Corrective Action Evaluation Process, Rev. 0, DOE/NV--1475. Las Vegas, NV.

U.S. Department of Energy, Nevada Operations Office. 1992. Remedial Investigation and Feasibility Study for the Plutonium Contaminated Soils at Nevada Test Site, Nellis Air Force Range and Tonopah Test Range. April. Las Vegas, NV.

U.S. Department of Energy, Nevada Operations Office. 1996. Final Environmental Impact Statement for the Nevada Test Site and Off-Site Locations in the State of Nevada, DOE/EIS 0243. Las Vegas, NV.

U.S. Department of Energy, Nevada Operations Office. 2000. United States Nuclear Tests, July 1945 through September 1992, DOE/NV--209-REV 15. Las Vegas, NV.

U.S. Environmental Protection Agency. 2002. Guidance for Quality Assurance Project Plans, EPA QA/G5, EPA/240/R-02/009. Washington, DC: Office of Environmental Information.

U.S. Environmental Protection Agency. 2006. Guidance on Systematic Planning Using the Data Quality Objectives Process, EPA QA/G-4, EPA/240/B-06/001. Washington, DC: Office of Environmental Information.

U.S. Environmental Protection Agency. 2013a. Pacific Southwest, Region 9: Regional Screening Levels (Formerly PRGs), Screening Levels for Chemical Contaminants. As accessed at http://www.epa.gov/region9/superfund/prg on 12 April. Prepared by EPA Office of Superfund and Oak Ridge National Laboratory.

U.S. Environmental Protection Agency. 2013b. SW-846, Test Methods for Evaluating Solid Waste, Physical/Chemical Methods. As accessed at http://www.epa.gov/epawaste/hazard/testmethods/sw846 on 12 April.

U.S. Geological Survey. 2013. “Groundwater Levels for Nevada.” As accessed at http://nwis.waterdata.usgs.gov/nv/nwis/gwlevels on 12 April. 


\section{Appendix B}

\section{Activity Organization}




\section{B.1.0 Activity Organization}

The NNSA/NFO Soils Activity Lead is Tiffany Lantow. She can be contacted at (702) 295-7645.

The identification of the activity Health and Safety Officer and the Quality Assurance Officer can be found in the appropriate plan. However, personnel are subject to change, and it is suggested that the NNSA/NFO Soils Activity Lead be contacted for further information. The Task Manager will be identified in the FFACO Monthly Activity Report prior to the start of field activities. 


\section{Appendix C}

\section{Nevada Division of Environmental Protection Comments}

(2 Pages) 


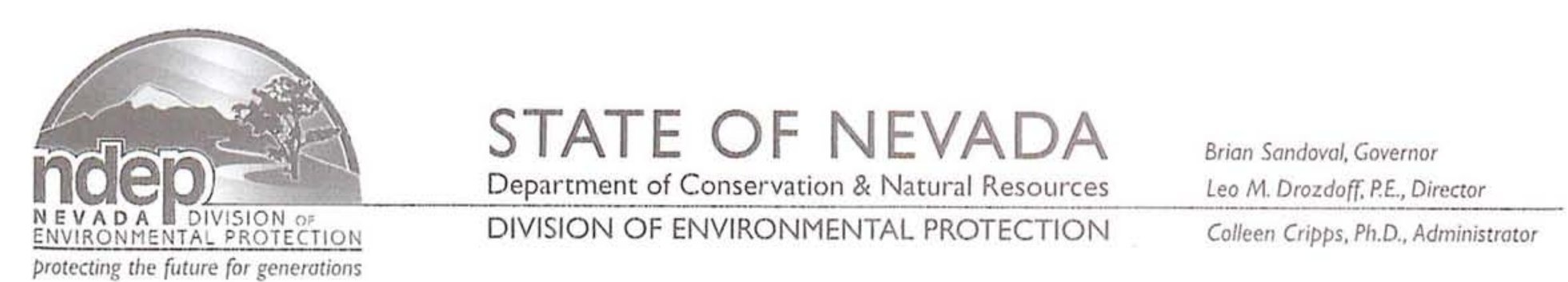

June 17, 2013

Robert F. Boehlecke, Manager

Environmental Management Operations

National Nuclear Security Administration

Nevada Field Office

P. O. Box 98518

Las Vegas, NV 89193-8518

RE: Review of Draft Corrective Action Investigation Plan (CAIP) for Corrective Action Unit (CAU) 571: Area 9 Yucca Flat Plutonium Dispersion Sites,

Nevada National Security Site, Nevada

Federal Facility Agreement and Consent Order

Dear Mr. Boehlecke,

The Nevada Division of Environmental Protection, Bureau of Federal Facilities (NDEP) staff has received and reviewed the draft CAIP for Corrective Action Unit (CAU) 571: Area 9 Yucca Flat Plutonium Dispersion Sites. NDEP's review of this document did not indicate any deficiencies.

If you have any questions regarding this matter contact me at (702) 486-2850 ext. 233.

Sincerely,

\section{/s/ Jeff MacDougall}

Jeff MacDougall, Ph.D.

Supervisor

Bureau of Federal Facilities

TZ/JW/SP

cc:

J. T. Fraher, DTRA/CXTS, Kirtland AFB, NM

N-I Central Files, MS NSF 156 (1 electronic copy)

NSTec Correspondence Management Coordinator, MS NLV008

T. A. Lantow, EMO, NNSA/NFO, Las Vegas, NV

FFACO Group, EMOS, NNSA/NFO, Las Vegas, NV 
NEVADA ENVIRONMENTAL MANAGEMENT OPERATIONS ACTIVITY DOCUMENT REVIEW SHEET

\begin{tabular}{|c|c|c|c|c|}
\hline \multicolumn{3}{|c|}{$\begin{array}{l}\text { 1. Document Title/Number: Corrective Action Investigation Plan for Corrective Action Unit 571: Area } 9 \text { Yucca Flat } \\
\text { Plutonium Dispersion Sites - DRAFT }\end{array}$} & \multicolumn{2}{|l|}{ 2. Document Date: May 2013} \\
\hline \multicolumn{3}{|l|}{ 3. Revision Number: 0} & \multicolumn{2}{|l|}{ 4. Originator/Organization: $\mathrm{N}-\mathrm{I}$} \\
\hline \multicolumn{3}{|c|}{ 5. Responsible DOE NNSA/NFO Subproject Mgr.: Tiffany Lantow } & \multicolumn{2}{|l|}{ 6. Date Comments Due: June 24, 2013} \\
\hline \multicolumn{5}{|l|}{ 7. Review Criteria: Full } \\
\hline \multicolumn{3}{|c|}{ 8. Reviewer/Organization Phone No.: Jeff MacDougall, NDEP, 486-2850 ext. 233} & \multicolumn{2}{|l|}{ 9. Reviewer's Signature: } \\
\hline $\begin{array}{l}\text { 10. Comment } \\
\text { Number/Location }\end{array}$ & 11. Type ${ }^{a}$ & 12. Comment & 13. Comment Response & $\begin{array}{l}14 . \\
\text { Accept/Reject }\end{array}$ \\
\hline 1.) None & & NDEP did not have any comments on the draft document. & & \\
\hline $\begin{array}{l}\text { 2.) Table A.2-3, page } \\
\text { A-10 }\end{array}$ & M & $\begin{array}{l}\text { Although not done in response to specific comments from NDEP, a change } \\
\text { was made to Table A.2-3. In the Study Group } 4 \text { column, VOCs and SVOCs } \\
\text { have been identified as a required analytical method. These are not } \\
\text { required analytical methods for Study Group } 4 \text { (drainage) and the table has } \\
\text { been updated to reflect this change. }\end{array}$ & $\begin{array}{l}\text { This change was discussed with } \\
\text { NDEP and approved. }\end{array}$ & Yes \\
\hline 3.) Table 4-1, page 52 & $\mathrm{~S}$ & $\begin{array}{l}\text { Although not done in response to specific comments from NDEP, a change } \\
\text { was made to Table A.4-1. The column heading "FFACO CASs" did not } \\
\text { adequately reflect the text in the column was revised. }\end{array}$ & $\begin{array}{l}\text { The column will be re-titled "Zone } \\
\text { Descriptions" }\end{array}$ & Yes \\
\hline 4.) Section 6.2, page 59 & M & $\begin{array}{l}\text { Although not done in response to specific comments from NDEP, a change } \\
\text { was made to Section 6.2. Section } 6.2 \text { needed to be revised to more } \\
\text { adequately align with the "Approved FFACO CAIP Outline." }\end{array}$ & $\begin{array}{l}\text { The section was revised to ensure } \\
\text { compliance with the approved FFACO } \\
\text { outline. }\end{array}$ & Yes \\
\hline & & & & \\
\hline & & & & \\
\hline & & & & \\
\hline & & & & \\
\hline & & & & \\
\hline
\end{tabular}

${ }^{a}$ Comment Types: $M=$ Mandatory, $S=$ Suggested.

Return Document Review Sheets to NNSA/NFO Environmental Management Operations Activity, Attn: QAC, M/S 50

\section{UNCONTROLLED When Printed}




\title{
Library Distribution List
}

\author{
$\underline{\text { Copies }}$
}

U.S. Department of Energy

Office of Scientific and Technical Information

P.O. Box 62

Oak Ridge, TN 37831-0062

Southern Nevada Public Reading Facility

c/o Nuclear Testing Archive

P.O. Box 98521, M/S 400

Las Vegas, NV 89193-8521

Manager, Northern Nevada FFACO

Public Reading Facility

c/o Nevada State Library \& Archives

100 N. Stewart Street

Carson City, NV 89701-4285
1 (Uncontrolled, electronic copy)

2 (Uncontrolled, electronic copies)

1 (Uncontrolled, electronic copy) 